\title{
PLACENTAL DEVELOPMENT IN THE SHEEP AND ITS RELATION TO FETAL DEVELOPMENT
}

\author{
A qualitative and quantitative anatomic and histologic study
}

JENNY H. J. STEGEMAN

Histological Laboratory, University of Amsterdam, The Netherlands

\section{CONTENTS}

Abstract . . . . . . . . . . . . . . . . . . . . . . .

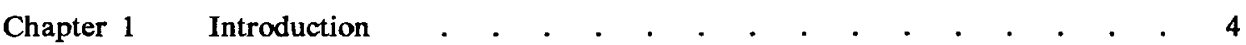

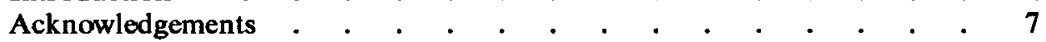

Chapter 2 Materials and methods . . . . . . . . . . . . . 7

\$2.1 Dissection of the uterus and its contents . . . . . . . . . . . . 7

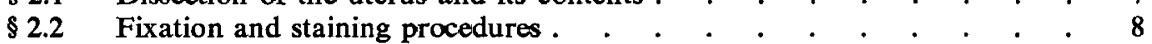

$\$ 2.3$ Quantitative methods . . . . . . . . . . . . . 12

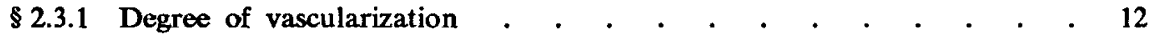

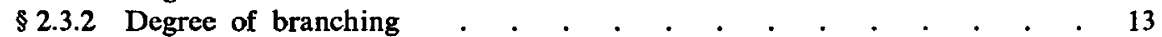

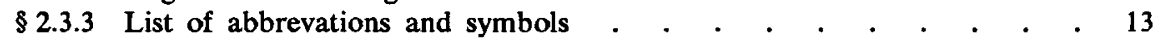

Chapter 3 Results. Macroscopic data . . . . . . . . . . . 14

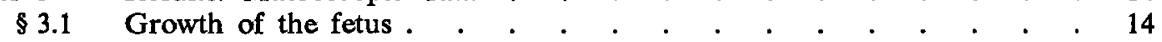

\$3.2 Growth and development of the placenta . . . . . . . . 16

$\$ 3.2 .1$ Number of cotyledons . . . . . . . . . . . . . 16

\$3.2.2 Growth of the fetal membranes . . . . . . . . . . . . . . . . 17

$\$ 3.2 .3$ Weight of the cotyledons . . . . . . . . . . . . . . . . $\quad$. 17

$\$ 3.3$ Growth of the uterus . . . . . . . . . . . . . 21

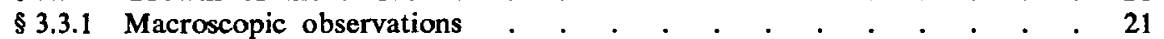

$\$$ 3.3.2 Differentiation of the caruncles. Microscopic data . . . . . . 23

Chapter 4 Results. The microscopic differentiation of the placenta in twin pregnancy 24

$\$ 4.1$ Branching of the villi. Introduction . . . . . . . . . . 24

$\$ 4.2$ Quantification of the villous branching . . . . . . . . . 26

$\$ 4.3$ The total villous surface of the cotyledonary mass. . . . . . . . . 27

$\$ 4.4$ The vascularization of the cotyledons. Introduction . . . . . . . . 28

$\$ 4.5$ Quantification of the vascularization of the villi . . . . . . . 30

$\$ 4.6$ The blood volume of the total cotyledonary mass. . . . . . . . . . 31

$\$ 4.7$ Relationships between the various parameters . . . . . . . 31

Chapter 5 Discussion of the data on twin pregnancies . . . . . . . . . . 56

Chapter $6 \quad$ Results. Findings in singlets and triplets . . . . . . . . . . . 60

$\$ 6.1$ Singlets $. . . \quad . \quad . \quad . \quad . \quad . \quad . \quad . \quad . \quad . \quad . \quad . \quad .60$

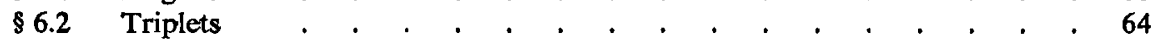

$\S 6.3$ Comparison of singlets and triplets with twins . . . . . . . . . $\quad$. 65

Chapter 7 Discussion . . . . . . . . . . . . . . . . . . . 66

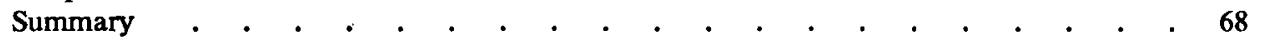

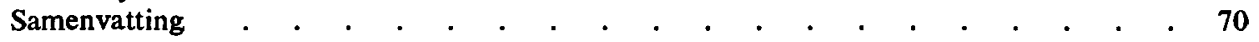

Literature . . . . . . . . . . . . . . . . . . . . 71 


\section{ABSTRACT}

A quantitative macroscopic and microscopic investigation was performed upon the placenta of the sheep.

Macroscopic data were obtained from 235 cases of single pregnancy, 285 cases of twin pregnancy, 45 cases of triplet pregnancy, and from one case of quadrulet pregnancy. Macroscopic data obtained include: weight of the uterine horns, weight of the fetal membranes, weight of the total cotyledonary mass, and weight of the fetus.

Microscopic data were mainly obtained from twin pregnancies (about 30 placentas in each of the nine age groups, group I being excluded from this investigation). The following microscopic data were calculated: vascularization of the caruncles (being the maternal component), degree of branching of the villi, total villous surface, vascularization of the villi, and total villous blood volume.

\section{CHAPTER 1. INTRODUCTION}

In all mammals the weight of the placenta shows a high degree of correlation with birth weight (for literature, see Naaktgeboren \& Stegeman, 1969). Only in cases in which non-physiological factors are manifest, this correlation may be absent.

The question can be asked as to what role the placenta plays in obtaining a certain birthweight. In man there are several heterogeneous factors which influence the normal growth of the fetus (see the review paper by Werner, 1972). Werner makes a distinction between disturbing conditions of maternal and of fetal origin. The placenta is involved in the majority of conditions, even in those of maternal origin. As an example it may be mentioned that the incidence of placental infarcts is higher in cases where diseases of the circulation are present in the mother (Fox, 1967). It has also been shown that the extent to which the placenta is affected by infarction is inversely related to birth weight (Kloosterman \& Huidekoper, 1954; Fox, 1967; Wigglesworth, 1964).

In this context, an experiment carried out by Creasy et al. (1972) must be mentioned. These authors were able to cause a reduction of $30 \%$ in the birth weight of sheep by disturbing uterine vascularization in a part of the placenta. They introduced carbonized microspheres with a diameter of $15 \mu$ into the arteries, which resulted in local occlusions. Those parts of the placenta in which vascularization was disturbed were found to be subject to structural alterations, with the cotyledons taking on a fibrous aspect. Creasy et al. concluded that the healthy condition of the trophoblast depends on uterine circulation. This situation is highly analogous to that prevailing in man in the case of infarction of the placenta. It is assumed that disturbances in the maternal circulation, and connected disturbances in the maternal-placental circulation, have to be considered as a primary cause of the majority of infarcts in the human placenta (Kubli, 1964; Wallenburg, $1969 ; 1971)$. Thus, in these cases there is also a disturbed or non-functioning uterine circulation in parts of the placenta.

In all these instances in which part of the placenta is inactive due to obvious causes, birth weight appears to be definitely subnormal. Mostly cases with pathological conditions are dealt with, and the questions can be asked whether, within physiological limits, the placenta also plays a role in influencing fetal growth and, also, which placental factors in particular determine the growth of the fetus.

There is evidence to suggest that, even under non-pathological conditions, a causal relationship exists between placental weight and birth weight. It also should be mentioned here that for a number of species it has been shown that the placenta stops growing well before the end of pregnancy (Barcroft, 1946a; Naaktgeboren \& Stegeman, 1969).

It is not possible to obtain a direct insight into the growth of the placenta in man, as is the case in animals. As regards prematurely born placentas, the situations resulting in premature delivery in a large proportion of cases have to be looked upon as being pathological; therefore no physiological growth curve can be deduced from such material. A second factor which renders it difficult to determine the growth pattern of the placenta in the last part of pregnancy is the circumstance that the time of normal spontaneous delivery shows a dispersion of four weeks.

Conclusions as to the course of placental growth in man therefore have to be based on circumstantial evidence. A number of data strongly suggest that after the 32 nd week the placenta could be a factor hampering growth because its capacity does not increase at the same pace as the demands made by the fetus. It should be mentioned that, according to the opinions of many authors who have worked on the subject (e.g. Boyd \& Hamilton, 1970), the human placenta keeps growing until the end of pregnancy. They base their opinion on the fact that the mean weights of placentas collected from spontaneous deliveries show a continuous increase even after the 42 nd week of pregnancy. 
Kloosterman (1965) has pointed out that this increase, as found in a transverse curve, might be misleading if larger placentas predispose to a longer course of pregnancy as compared with smaller placentas. He found the following arguments supporting this:

Classifying a large number of newborns and placentas according to the duration of pregnancy, the mean weights of both placentas and newborns showed a continuous increase. A reservation has to be made in that the curve shows a slight decline which becomes apparent for the weight of the newborns from the 38 th week onwards, and even slightly earlier for the placentas.

Looking at the placental index (weight of the placenta divided by the weight of the newborn) it appears that there is a continuous decline as pregnancy proceeds. At the 38th week, however, this decline comes to a halt and, up to the 46th week, the curve of the placental index is flat.

As it is a given fact that the fetus still increases in weight after 38 weeks, the phenomenon could be explained in two ways:

1. By assuming that the growth of the placenta, which until then has lagged behind that of the fetus, suddenly shows an equal pattern of growth.

2. By assuming that the placenta stops growing in the last weeks of pregnancy while the fetus goes on growing until a certain relationship to the placental weight is reached and the fetus is born.

According to Kloosterman (op. cit.) the first hypothesis is improbable, because the placenta already shows signs of obsolescence after the 32nd week of pregnancy, which makes it most improbable that this organ would undergo a growth acceleration during the last period of its existence.

This leaves the assumption that the placenta stops developing some weeks before parturition, after which the fetus keeps growing until a constant relationship within narrow limits is reached. In this way it can be explained why the unborn child shows a growth delay for a short period before birth (maximum placental capacity has been reached); it also explains why placentas which are born later show an increased mean weight (in cases where there is a heavy placenta the child can keep on growing for a longer time and, because of the bigger placenta, the pregnancy may be continued for a longer period), and why the placental index is constant after 38 weeks.
The work of Winick, Coscia \& Noble (1967), who found that the total content of DNA in the placenta did not increase after the 34th week, agrees with this hypothesis.

Finally, the hypothesis that the placenta stops growing first and the fetus continues growing until the given relationship between placental weight and the weight of the fetus has been reached, has been tested in sheep by Naaktgeboren \& Stegeman (1969). They found a very low correlation coefficient between the placental weight and the fetal weight in the early stages. In the later stages (about the last 4-6 weeks of pregnancy) the correlation coefficient was very high, which confirms the hypothesis set out earlier.

It should be mentioned also that the pregnadiol. secretion curve in man levels off after 32 weeks (Kloosterman, 1965). Since this parameter is considered as a value measuring the function of the placenta, this finding may indicate that the capacity of the placenta no longer increases after the 32nd week.

A number of data indicate that, in the last weeks of human pregnancy, the placenta becomes a restrictive factor for fetal development, possibly because of retardation or arrest of its growth.

One of the indications is found in growth patterns of singlets and twins. The fetal weights diverge after the 32nd week, with the twins lagging behind. It is known that at the end of twin pregnancy the total amount of placental tissue is higher than in singlet pregnancy, but that the individual placentas are smaller.

After the 32nd week, differences in fetal weights develop when comparing first and second or later pregnancies, the placenta in a first pregnancy being lighter. This phenomenon is also observed in animals and is ascribed to the fact that tho uterus in later pregnancies presents a more favourable environment for the development of the placenta.

The time of development and the intensity of the placental constraint depend on the size of the placenta at the moment its growth is retarded or arrested. This, for instance, is the case in twin pregnancy as compared with singlet pregnancy. This constraint is also to be seen in those cases in which part of the placenta is inactive because of, for example, infarctions. The degree of infarction is inversely proportional to the weight of the newborn (Kloosterman, 1963; Fox, 1967; Schuhmann, 1969; Battaglia, 1970; Busch, 1972; Scott \& Jordan, 1972). 
If the growth of the human placenta comes to a standstill several weeks before parturition, as is the case in other mammals, this situation poses some questions. Firstly it becomes relevant to ask whether or not the placenta has some means to increase its efficiency, which are not reflected in its mass.

A second question results from the following considerations. The above mentioned data indicate that the placenta cannot adequately supply all the factors necessary for an optimal development of the fetus under all circumstances. Depending on the size which the placenta has obtained at the moment it stops growing, a more or less strong limitation of fetal growth will occur. Scott \& Uscher (1966) have also shown that, in cases of intra-uterine growth retardation of the fetus, a normal placental index is found. The placenta in those cases is mature but too small for the duration of pregnancy. In a number of cases these under-weight children are born prematurely. The placenta in those instances is characterized by a completed histological maturation (Becker, 1960), a condition referred to as "maturitas praecox". This condition is characterized by an excessive proliferation of blood vessels in the placental villi. These placentas are seemingly quite normal, though under-weight; the newborns are under-weight also, but developed according to the duration of pregnancy. The view has been put forward that an accelerated maturation of these small placentas is a means of attempted compensation for their small size (Becker, 1960; Werner, 1972). So, a second question underlying the study to be described is: what evidence can be produced to substantiate the view that the placenta has at its disposal an adaptive mechanism ("maturitas praecox") which makes it possible to compensate for (physiological) deviations, specifically a small size?

In man it is difficult to decide whether this condition of maturitas praecox has to be looked upon as an accelerated maturation, i.e. a physiological compensatory mechanism, or has to be considered as a non-physiological phenomenon. To obtain human material from all stages of normal pregnancy is not possible; as a rule cases of premature delivery will have to be considered as being pathological.

To gain an insight into the relationship between weight of the uterus, fetal weight and the characteristics of the placenta, the study to be described was performed on the uteri of sheep of the Texel breed which were found to be pregnant in the slaughterhouse. The sheep is well-suited for this type of investigation not only because it is a fairly large mammal but also because the duration of pregnancy is rather long (145 days). Singlets and twins occur in about equal numbers, and triplets are not very exceptional. The sheep's placenta differs from the human placenta since it is of the epitheliochorial cotyledonary type (Björkman, 1965; 1970). The sheep's uterus also is different from the human uterus. Instead of a uterus simplex, the sheep has a uterus bicornis. Judging from the number of ovulations in each cycle ( 2 or more) it has to be concluded that, in the Texel sheep, twin pregnancies have to be considered normal. This is not the rule for all breeds: sheep of the Drenthe-moor breed, for instance, give birth to one lamb per season (Naaktgeboren, BakkerSlotboom, van Maren \& Stegeman, 1971); the litter size in other fresian milk sheep breeds may be 4 or even 5 in exceptional cases.

In an earlier investigation (Naaktgeboren \& Stegeman, 1969) the following data were obtained: the weight of the placenta in Texel sheep increases only until about halfway through the duration of pregnancy, the total duration being 21 weeks. At that time the fetus has only obtained about one-fourth of its ultimate birth weight.

The important question arises as to what mechanism makes it possible for the placenta - which grows no longer - to meet the increasing demands made by the fast-growing fetus. It is this question which formed the starting point for the present study.

Essentially, three means for coping with such a situation appear to be possible: 1. diffraction, i.e. branching of the villi, resulting in an enlargement of the total surface across which the exchanges between fetal and maternal components take place; 2 . an increase in the vascularization of the villi; 3 . an improvement of the means of exchange by alteration of the barrier which separates the maternal from the fetal circulation.

On these points there is no essential difference between sheep and man. In man also these three mechanisms occur more or less in this order during the course of pregnancy. The study to be presented aimed at a quantitative approach to describe the differentiation of the villi and the increase in vascularization in order to make it possible to compare placentas of different ages and sizes. 
Summing up this introduction, the two questions underlying the study to be presented can be formulated as follows:

First: Which mechanism of placental differentiation in the sheep makes it possible to meet the demands of the growing fetus when placental growth has come to an end? Can differentation be described in quantitative terms? Is the pattern of differentiation similar to that in man?

Secondly: Do physiological variations in placental development occur, which make (physiological) compensatory mechanisms manifest? This question refers to the possibility of an accelerated maturation, similar to the maturitas praecox syndrome in man.

The quantitative part of the investigation was carried out on an extensive range of material obtained from twin pregnancies. Smaller amounts of material obtained from singlet and triplet pregnancies will be dealt with separately.

The choice of twins as a main object of study has been determined by two considerations. It is in these pregnancies that the available space in the uterus (bicornis) of the sheep is filled completely, a condition similar to that found in singlet pregnancies in the human. Secondly, it is in these pregnancies that fortuitously exceptionally small placentas may be found as a result of competition for space, without the situation being pathological.

\section{ACKNOWLEDGEMENTS}

I am gratefully indebted to Dr. A. van den Hooff for his stimulating discussions based on real interest in the subject. I thank him for his help translating most part of the manuscript in readable English.

Prof. Dr. G. J. Kloosterman is acknowledged for his advices and help concerning the human placenta. I am thankful to Dr. C. Naaktgeboren, who initiated the basic studies of this investigation which were published before.

I am indebted to Prof. Dr. J. James, present head of the Histological Laboratory of the University of Amsterdam, for his personal interest in and critical remarks on the work. I am thankful to Prof. Dr. D. B. Kroon and Prof. Dr. J. James for their hospitality in the laboratory and the opportunity offered to complete this study.

I am greatly indebted to Lidia Jongstra-Spaapen for her perseverance in collecting and preparing the histological material, assisted by Claes Schuyt whose help is greatly acknowledged.

Thanks are due to Drs. F. I. van Moppes and Drs. W. J. van der Velde for their accuracy during the laboratory measurements.

I would like to express my gratitude to Mr. A. J. P. de Meere for writing the computer program and for his assistance in working up the data; to Ir. J. M. Houtkoper for the statistical supervision and stimulating skepsis; to Prof. Dr. P. Visser for his cooperation using his computer.

Thanks are extended to Herman Spijker for his encour- aging patience introducing $m e$ in the secrets of the histological techniques.

Many thanks to Mr. J. van Dusschoten and Mr. E. J. J. Eerkens for drawing the illustrations and to Mr. J. Peeterse and $\mathrm{Mr}$. N. Brandjes for preparing the photographs and Mr. J. Zaagman for making all the illustrations ready for press.

I am particularly grateful to Trees Pierik for typing the manuscript and to Mrs. F. Peeters-Pieters, editorial secretary, for her continuous advice and assistance making corrections.

I am very grateful to Piet Bakker, sheep breeder on the island of Texel. He gave me a lot of inside-information about the Texel breed and offered me many accurate data about his animals.

Sincere gratitude to all not explicitly mentioned, who contributed to the completion of this work.

\section{CHAPTER 2. MATERIALS AND METHODS}

The material used in this investigation was obtained from sheep of the Texel breed, brought to the slaughterhouse in Amsterdam. As a rule a large proportion of the ewes, which are brought to the slaughterhouse during the months October to March, are pregnant. Pregnant uteri were made available for this investigation, thanks to the kindness of the managing board, superintendents and butchers. The intact uteri and their contents were brought to the laboratory, where they were dissected according to the following procedure.

\section{$\S 2.1$. Dissection of the uterus and its contents}

The two ovaries and the remaining part of the cervix were removed. In the greater part of the total material the osteum externum was missing because, in the slaughterhouse, the cervix had been cut off. For this reason it was not possible to determine the parity of the ewe.

The length of each horn was measured along the major curvature, reaching from the top of the horn to the internal osteum.

An incision was made in the intercornual ligament ( $\mathrm{L}$ in fig $1, \mathrm{~A}$ ) which made it possible to separate the two horns by careful traction. Following separation, the situation was as presented in fig. 1, B. In this figure the hatched line indicates the area along which the two horns were linked together by the ligament.

The corpus uteri was cut open (fig. 1, D), so that the contents became visible and, in the case of twins, it became possible to find the area where the chorion of the left fetus was attached to that of the right fetus (arrows in fig. 2, A and $\mathrm{B})$.

This border was not always situated exactly in the middle of the corpus uteri. It also marked 


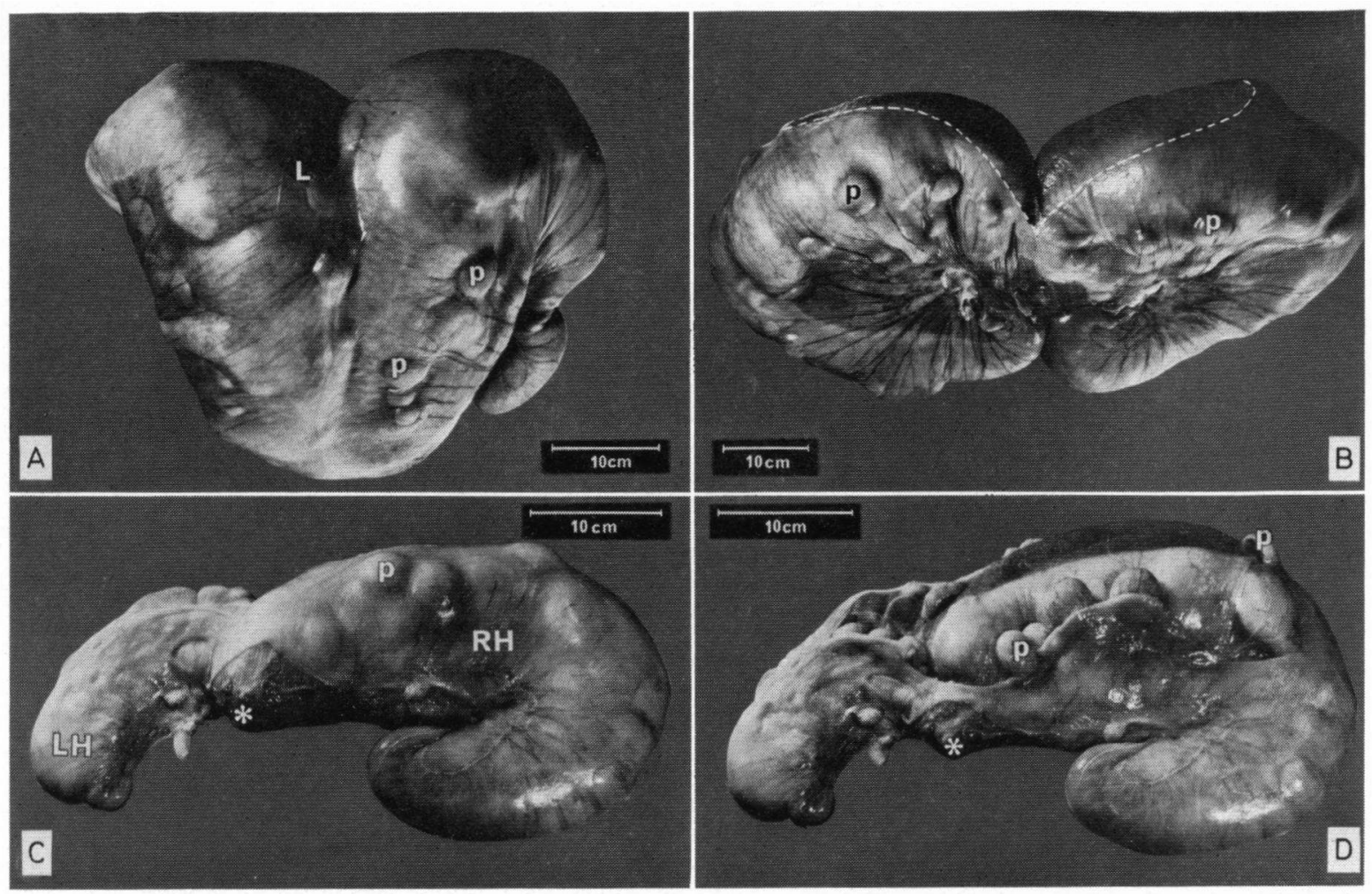

Fig. 1. A. Dorsal view of a single uterus containing twins. The ligament $(L)$ links the right and left horns. $\mathrm{P}=$ placentomas as seen through the wall of the unopened uterus.

B. Same uterus as shown in $A$, after cutting the ligament. The dotted line indicates the area where the two horns were connected.

C. Dorsal view of a single uterus containing a singlet. The connecting ligament has been cut. The left horn (LH) is not pregnant; the right horn (RH) contains the fetus. ${ }^{*}=$ the remains of the cervix uteri.

D. The same uterus as shown in C. The uterine wall has been cut and the fetus is exposed.

the line of separation between the two areas of placental blood supply. Unlike the situation in the cow, placental anastomoses are rarely found in the sheep (Steven, 1968), and in the present material no instances of placental blood vessel anastomoses were found.

In the cases of triplet pregnancy it was possible to distinguish the three fetal sacs in a similar way.

In those cases in which the line marking the attachment was poorly visible it was possible to distinguish the two (or three) areas by their respective vascularizations, i.e., by examining the paths of the blood vessels.

In the case of a single pregnancy the fetal membranes were cut in two along a line dividing the left half from the right half. Consequently, in the material from single pregnancies reference was always made to the pregnant and the nonpregnant horn. In the case of a single pregnancy the placenta also occupied part of the second horn, but the fetus occupied only one of the two horns (figs. 1, C and 1, D).

\section{§ 2.2. Fixation and staining procedures}

After 24 hours of fixation, a slice 3-4 mm thick was cut from the middle of each placentoma and immersed in $12 \%$ formalin. The slices were processed by means of automatic equipment (histokinette). After treatment with graded alcohols, methylbenzoate and toluene, the slices were embedded in Ralwax.

Sections of $6 \mu$ thickness were cut from each piece of tissue. Two stains were applied: the combined Alcian blue-PAS staining and a modified trichrome staining according to Masson-Goldner. This second method was modified as follows:

from aqua dest.:

Weigert hematoxylin I + II

Rinse in aqua dest.

Masson solution

Short rinse in acetic acid $0.5 \%$

Phosphotungstic acid $2 \%$ diff.

Orange yellow solution

Rinse in acetic acid $0.5 \%$ fast green

Quick rinse in acetic acid $0.5 \%$

Aqua dest., mounting in Damar resin
5 minutes

15 minutes

3.5 minutes

25 minutes

25 minutes

30-40 minutes 

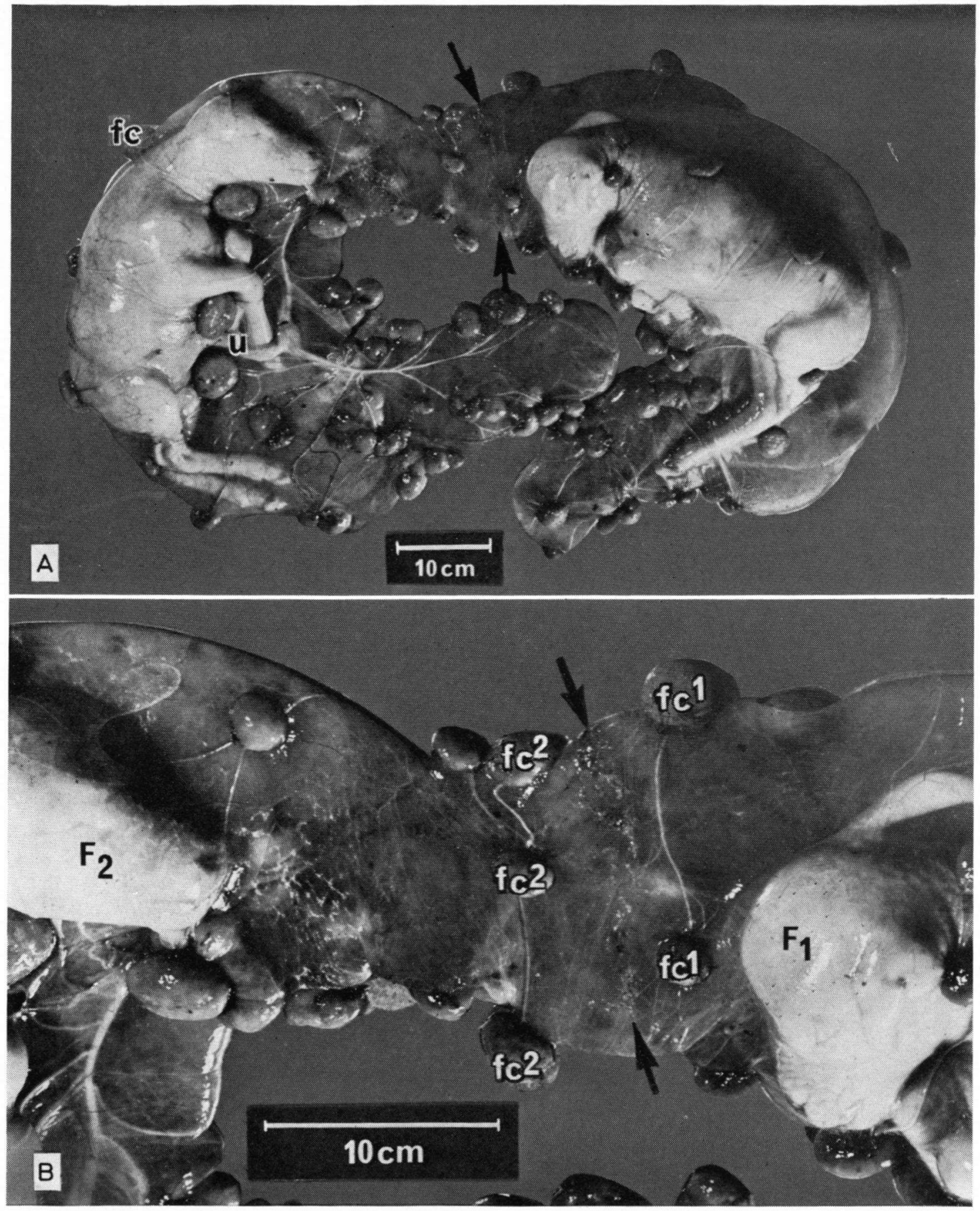

Fig. 2. A. Pair of twins prepared in the membranes taken from the uterus. fc is the cotyledon, the fetal component of the placentoma. Note the course of the vessels running from the individual cotyledons to the umbilical cord (u) and vice versa. The arrows indicate the line where the two chorionic membranes are fused.

B. Detail of $A$. The cotyledons $f c_{1}$ belong to the circulation of fetus $F_{1}$. The cotyledons $f_{c_{2}}$ are the most extreme cotyledons of the circulation of the second fetus $F_{2}$ The arrows indicate the line along which the two chorionic membranes are fused. 


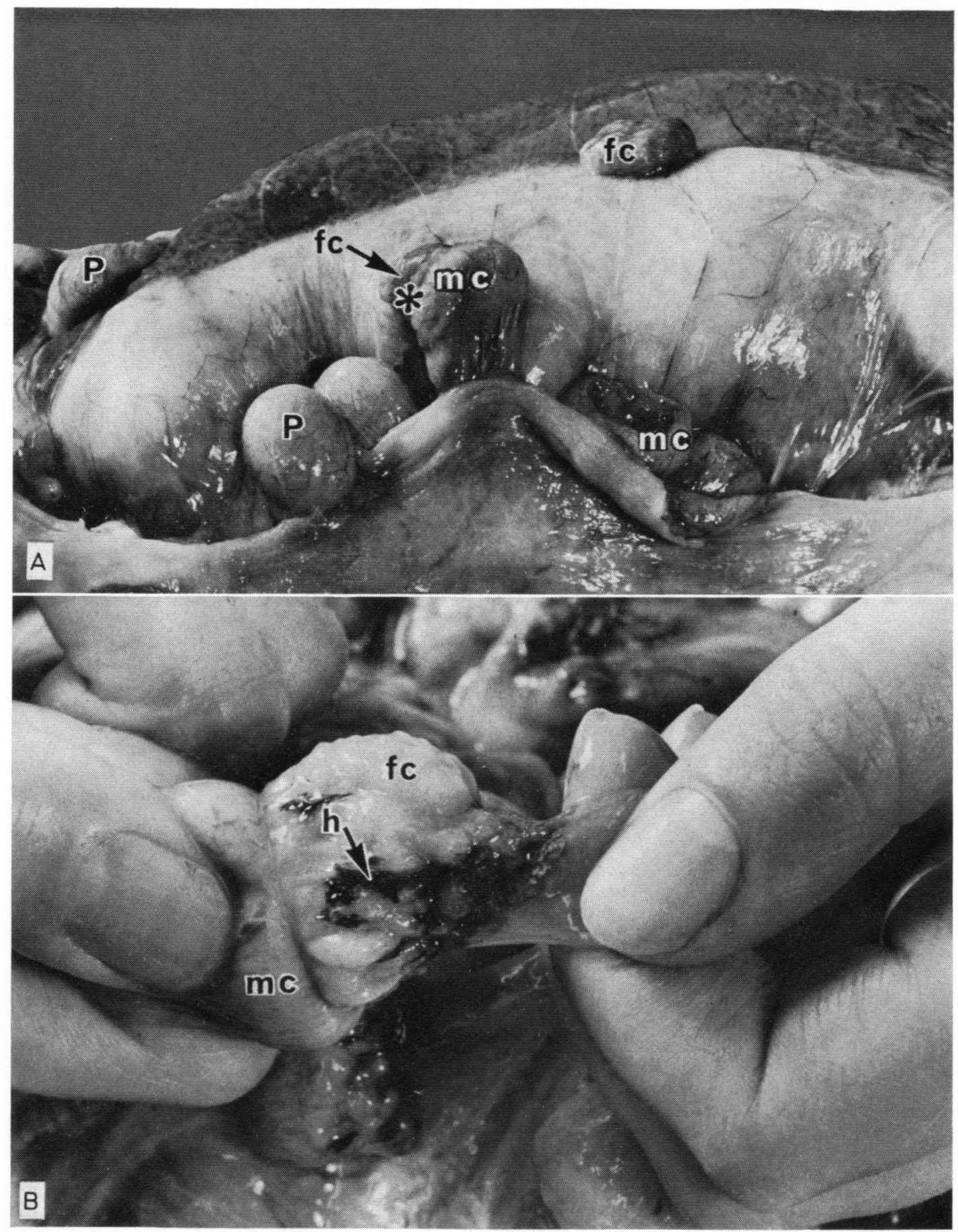

Fig. 3. A. Detail of the same opened uterus as presented in fig. 1, D. The fetal membranes are still intact. At * the caruncle and cotyledon separate. For abbreviations, see \$ 2.3.3.

B. Caruncle and cotyledon are separated by squeezing the caruncle $(\mathrm{mc})$ with gentle traction on the cotyledon (fc). $h=$ hematoma. 
As a result of this modified staining method the erythrocytes were coloured a bright orange-red and stood out more clearly against a dark green background than in the original staining.

This method made it possible to distinguish clearly between the blood vessels and their contents on the one hand and the rest of the tissue on the other hand, a prerequisite for the quantitative methods mentioned below.

From each placenta one placentoma (i.e. caruncle plus cotyledon) was fixed as a unit in a $12 \%$ formalin solution. This placentoma ( $P$ in fig. $3, A$ ) was taken from a site where the vessels which are present on the whole surface of the fetal membranes converged and entered the umbilical cord. In the case of a single pregnancy, placentomas both from the pregnant and the vacant horn were obtained. The membranes were cut, the amniotic fluid was collected if possible, and the embryo was taken out. Crown-rump length, sex and weight were determined. The fetuses were classified into ten age groups (I - X) using the parameters: length, weight and external appearance. The classification was that proposed in an earlier publication (see table I).

The fetal membranes were then removed from the uterine horns by pushing the cotyledons carefully out of the caruncles (fig. 3, B). In the cases of multiple pregnancy the fetal sacs were separated along the attachment line of the chorionic membranes. Membranes and cotyledons were first weighed together. Then the cotyledons were cut loose from the chorion, and the total mass of cotyledons was weighed after counting their number. The uterus was cut through the centre of the corpus uteri and the two halves were weighed. The total number of uteri studied was 565. There were 235 single pregnancies, 285 twin pregnancies and 45 triplet pregnancies.

Table I. Age determination criteria (after Naaktgeboren \& Stegeman, 1969).

\begin{tabular}{|c|c|c|c|}
\hline Group & $\begin{array}{l}\text { Age in } \\
\text { weeks }\end{array}$ & $\begin{array}{l}\text { Crown-rump } \\
\text { length in } \mathrm{cm}\end{array}$ & $\begin{array}{c}\text { Weight in } \\
\mathrm{g}\end{array}$ \\
\hline I & 1 to 4 & 1 & 1 \\
\hline II & $5+6$ & $2-5.9$ & $1-9$ \\
\hline III & $7+8$ & $6-10.4$ & $11-27$ \\
\hline IV & $9+10$ & $10.5-15$ & $60-150$ \\
\hline $\mathbf{v}$ & $11+12$ & $15-24$ & $200-700$ \\
\hline VI & $13+14$ & $24-30$ & $700-1000$ \\
\hline VII & $15+16$ & $29-36$ & $1100-2000$ \\
\hline VIII & $17+18$ & $34-41$ & $2000-3000$ \\
\hline IX & $19+20$ & $40-46$ & $3000-4000$ \\
\hline $\mathbf{X}$ & 21 & 45 & 4000 \\
\hline
\end{tabular}

Small embryo with bud-shaped leg-rudiments

Curved embryo or fetus with a definite ungulate aspect

No manifest hair papillae

Manifest papillae on the eyelids and on the snout

First hair on the eyelids and on the snout to welldeveloped hair on the snout. Hair papillae at the sites of the future horns and on the neck.

Papillae to first hairs on the neck.

First hairs to distinct hairs at the sites of the future horns. Papillae or hairs on the prepuce.

Neck: short to long hairs. Crown and sites of the horns: manifest hairs to hair-whirls. Legs: incipient to manifest hair. Hindlegs less advanced than forelegs.

Short hairs on the whole fetus. Neck: longer hairs to curls.

Hair coat complete. Curls spreading from cranial to caudal regions. Hairs still rather short. Eyes closed. Lids can be separated. No erupted teeth.

Whole body covered with curly hair. Only the dorsal aspect of the nose and legs bear long, smooth hairs; teeth and molars erupt. Eyelids are no longer fused.

The data on the crown-rump length refer to single pregnancies; they do not represent the outer limits but indicate the limits within which the majority of observations are situated.

The age in weeks (column 2) is based on data given by Malan \& Curson (1936) and by Cloethe (1939). 

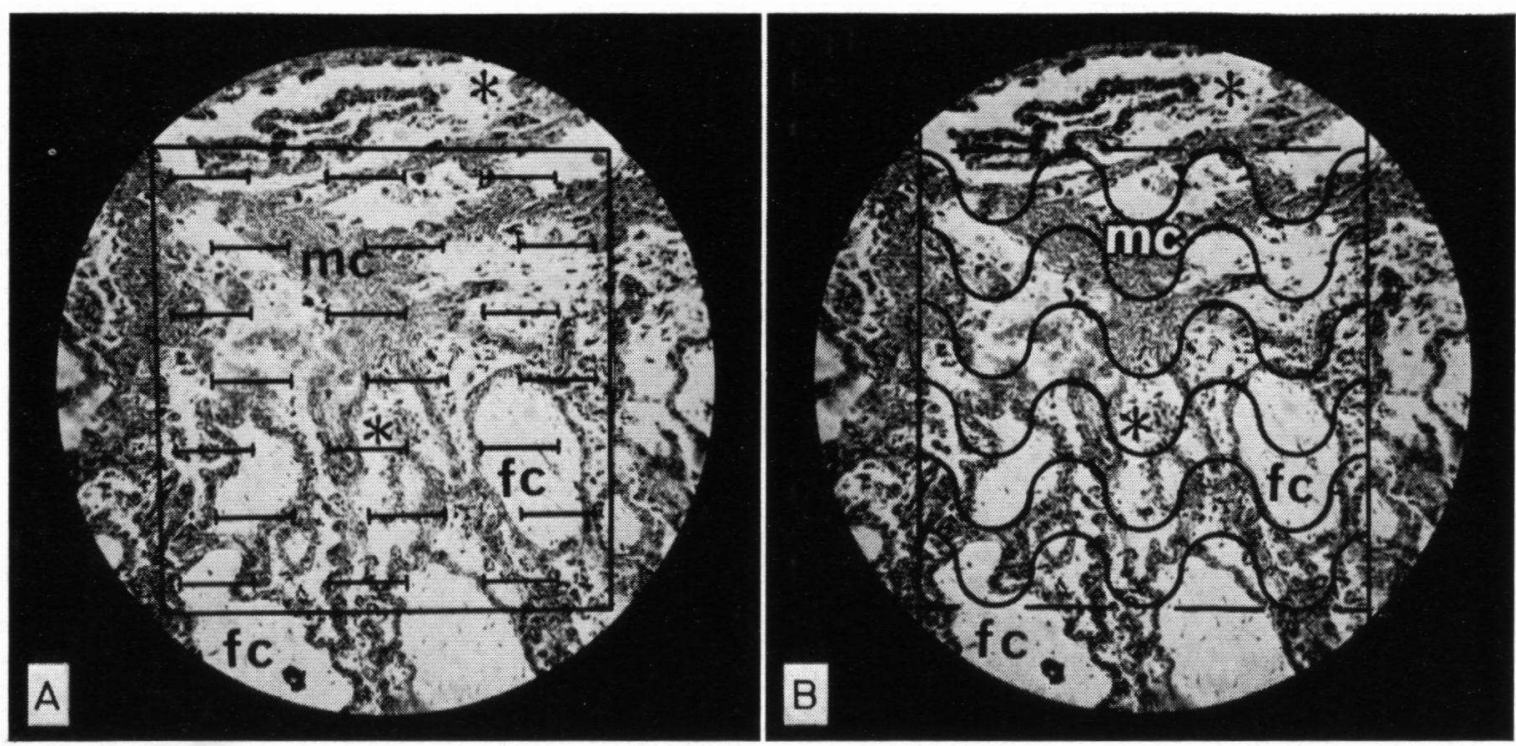

Fig. 5. A. The projection head of a Wild-Microscope with the Weibel grid used in the "Punktzahl" method.

Reduced; the square measures $10 \times 10 \mathrm{~cm}$.

B. The same area as shown in $A$, with a grating of semicircular lines as described by Merz, used for the determination of branching degree and villous surface.

For abbreviations, see $\$ 2.3 .3 ; *=$ artificial space.

All data from each uterus could not be registered in all cases. Sometimes it happened that in the slaughterhouse one fetus of a pair of twins was lost, the placenta of this fetus still being present in the uterus. In such a case the remaining partner was included with the other sets of twins for the determination of the mean fetal weight of its group. Similarly, the remaining placenta in the case of a missing fetus was included in the total for the overall determination of the mean placental weight of its group. For this reason it happens that in most tables the number of individual twins is not always an even number. For the same reason the number of individual triplets is not always a multiple of three.

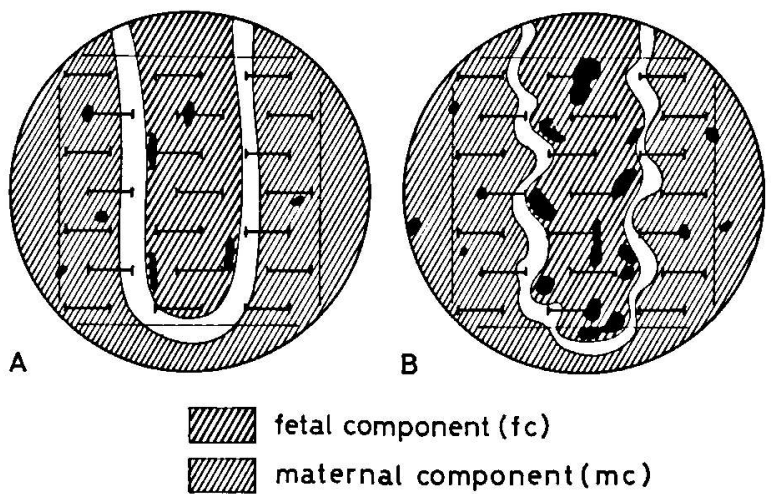

\section{§ 2.3 Quantitative methods}

\section{$\S$ 2.3.1 Degree of vascularization}

In each section through a cotyledon the following components were distinguished: maternal non-vascular tissue, maternal blood vessels, fetal non-vascular tissue, fetal blood vessels and artificial spaces between maternal and fetal tissue (figs. 4 and 5).

The proportion of each of these components was determined using a point-counting method as described by Weibel (1969). No attempt was made to calculate the actual volumes from the surface
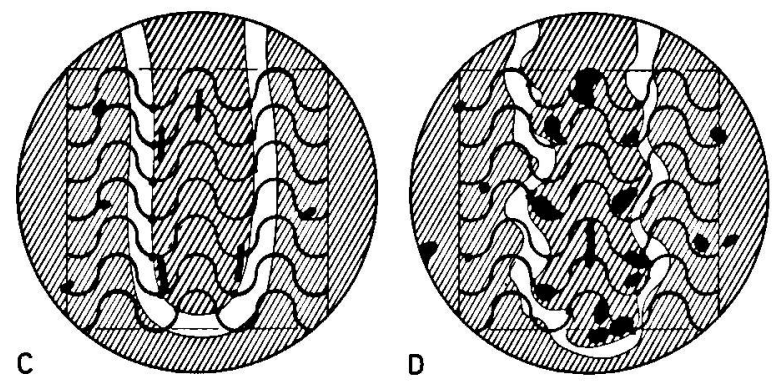

space caused by shrinkage

blood vessel

Fig. 4. Schematic representation of the two histometric sampling methods used in this investigation.

$A$ and $B$ respectively represent younger and older placental tissue. The total villous mass does not change significantly, whereas the number of fetal vessels increase, as do the number of "hits" in a vessel.

$\mathbf{C}$ and $\mathbf{D}$ again represent younger and older placentas together with the grating used for determining the villous outline. The number of times the semi-circular lines cross the villous outline increases as the shape of the outline of the villus becomes more complex. 
area measurements. Arbitrary units were used which gave sufficient information to compare the placentas of different ages or weights. In 80 fields on each slide, a total of 1000 points was counted; the magnification was $\times 290$. The original grid contains 42 points (figs. $4, A$ and B; 5, A), but in the present study it was more feasible to count alternately 12 and 13 points per field, i.e., 25 points per two fields. The areas where subchorial hematomas were situated were excluded from the count, as were the fields in which part of the uterine wall was visible. A Wild 501 sampling microscope was used. This microscope allows for a periodic shift of the stage in a forward, backward or sideward direction. The length of the shifts, i.e. the distances between the fields, could be set at will. This makes random sampling possible. In large cotyledons the distance between two fields of measurement was selected at a higher value than in small cotyledons.

The counting of 1000 points resulted in data on the distribution of the 5 components in each specimen. The index or degree of vascularization of the cotyledons was calculated as follows:

Counts per 1000 of fetal vessels (including vessel wall) divided by the total fetal tissue (= counts per 1000 of total fetal tissue including vessels, vessel walls and non-vascular tissue). In the following text this parameter - expressed in arbitrary units will be referred to as the degree of vascularization. The parameter "fetal placental blood volume" as used in this investigation, was obtained by multiplying the degree of vascularization by the weight of the total cotyledonary mass (in grams). This parameter was used only for comparison as it gives no definite information about the absolute amount of fetal blood in the placenta.

When reference is made to the degree of vascularization of the uterus, this parameter was calculated in a similar way as the vascularization of the cotyledons; counts per 1000 of maternal blood vessels divided by the counts of maternal tissue (including maternal blood vessels and maternal non-vascular tissue).

\section{$\S$ 2.3.2 Degree of branching}

Using another type of test grid (Merz, 1967) in the projection screen of the microscope (fig. 5. B), it was possible to quantify the degree to which the villi were branched (fig. 4, C and D). Twenty fields of view in each slide, magnification 72.5 , were selected in the same random way as described in the preceding section. From each coty- ledon, one slide was measured. The length of the contour lines present in a field of view could be expressed as the number of points of crossing these lines. The degree of branching was calculated by division of the number of these crossings by the number of the points of fetal tissue (fetal tissue + fetal vessels) as was found by applying the pointcounting method on the same slide.

The grid lines represented an equal distribution of directions from $0^{\circ}$ to $360^{\circ}$, which eliminated variations due to any predominant orientation of the lines to be measured. The grid consisted of 6 wavy lines formed from semicircles (fig. 5, B). It appeared more feasible to count only 3 alternate lines in 20 fields, rather than to count all 6 lines in only 10 fields.

A parameter for the total surface of the villi was obtained by multiplying the degree of branch. ing by the weight of the total cotyledonary mass. As in the case of fetal placental blood volume, this surface is not expressed in metric units but in arbitrary units, since it only had to serve as a parameter for comparative purposes.

In view of practical limitations, the quantification procedure was carried out mainly on material from twin pregnancies, since in sheep the uterus is occupied fully in twin pregnancies. In addition, a number of observations were made in triplet and single pregnancies; these observations will be mentioned in chapter 6 .

\section{§ 2.3.3 List of abbreviations and symbols ABBREVIATIONS}

$\begin{array}{ll}\text { cb } & \text { caruncular base } \\ \text { ep } & \text { epithelium } \\ \text { F } & \text { fetus } \\ \text { fbv } & \text { fetal blood vessel } \\ \text { fc } & \begin{array}{l}\text { fetal component of the placentoma (i.e. } \\ \text { cotyledon) }\end{array} \\ \text { h } & \text { hematoma } \\ \text { L } & \text { ligament } \\ \text { LH } & \text { left horn } \\ \text { mbv } & \text { maternal blood vessel } \\ \text { mc } & \text { caruncle (i.e. maternal component of the } \\ & \text { placentoma) } \\ \text { mes } & \text { mesenchymal tissue } \\ \text { P,p } & \text { placentoma } \\ \text { RH } & \text { right horn } \\ \mathbf{u} & \text { umbilical cord }\end{array}$

SYMBOLS

N.B. Unless further specifications are given, the meaning of the symbols is as follows:
open symbols
: male fetuses
closed symbols : female fetuses
half-filled symbols: total population of male and female individuals
triangles : singlets
circles : twins
squares : triplets 


\section{CHAPTER 3. RESULTS. MACROSCOPIC DATA}

\section{§3.1 Growth of the fetus}

The increase in fetal weight is presented in fig. 6. From group VIII onwards there are marked differences in the average fetal weights of singlets, twins and triplets. The collected material contained only one case of quadruplet-pregnancy in which there were three female fetuses weighing respectively 1157,1155 and 1140 grams and one male fetus weighing 1410 grams. They were classified as belonging to group VII. In all four the weights were below those given in table $I$ for males and females in group VII.

Both in singlets, twins and triplets small differences gradually appeared between the average weights of male and female fetuses from groups V or VI onwards (fig. 6). Generally the males are somewhat heavier than the females. These differences are especially marked in the weights of newborn lambs $\left(\mathrm{N}_{1}\right.$ and $\mathrm{N}_{2}$ in table II). However, the differences are not large, and in the singlets in group $X$ the average weight of the females is even higher than that of the males.

As was shown earlier, the influence of placental weight on birth weight is greater than that of the sex of the fetus (Naaktgeboren \& Stegeman, 1969). As a rule the male fetus will become heavi- er than the average female fetus, provided that the placenta can meet the demands made by the male fetus. If this is not the case, the weight of a male fetus can be substantially lower than that of a female fetus.

Within the fetal groups, as well as in newborn lambs, the weights show large deviations from the average (Naaktgeboren \& Stegeman, 1968). This dispersion is highest in the older groups. In these groups the weight increases are also largest, and show an almost exponential course. In this second part of pregnancy, factors which hamper growth have increasing influence. The increase of the standard error of the mean, which indicates an increase in dispersion within the groups, can be explained by these factors. The same is all the more true for the newborn animals from both primiparous and pluriparous mothers. ${ }^{1}$ )

These facts are well known in veterinary practice, and are again illustrated in groups $N_{1}$ and $\mathrm{N}_{2}$ in table II. This table gives data on lambs born on one farm in the spring of 1972. Fortunately, on this farm parity and litter size of each sheep are carefully registered.

1) In this respect biological terminology differs from medical terminology. Multiparous in the biological sense means that a mammal gives birth to a litter. Uniparous mammals give birth to only one offspring. In medical terminology multiparous denotes a woman who gives birth not for the first time.

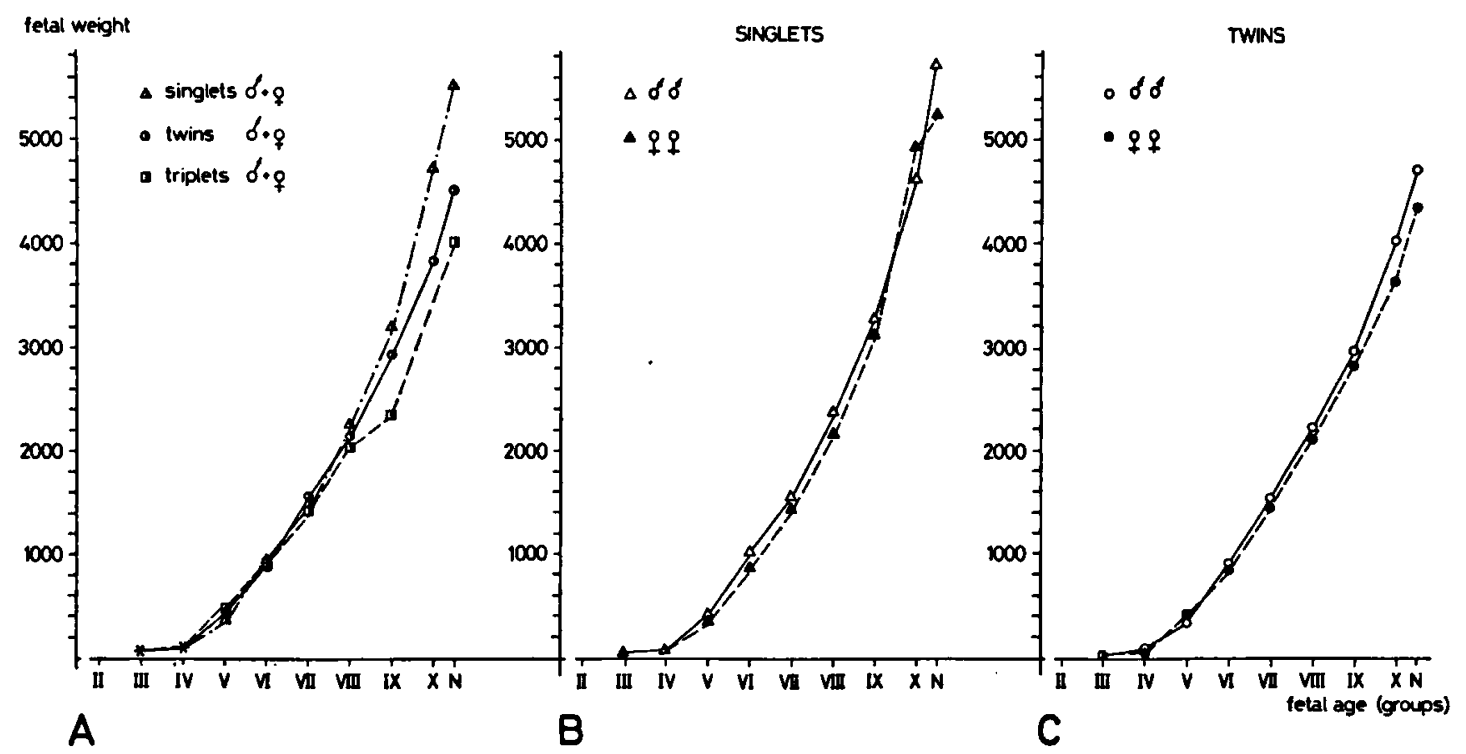

Fig. 6. Fetal weights (in g).

A. Comparison of singlets, twins and triplets. B. Singlets, $\hat{\delta} \delta$ and $q q$ separately. C. Twins, $\hat{\delta} \hat{\delta}$ and $q \uparrow$ separately. 


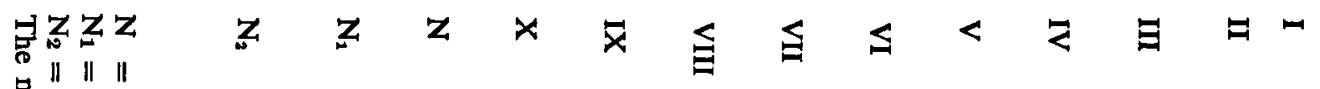

“

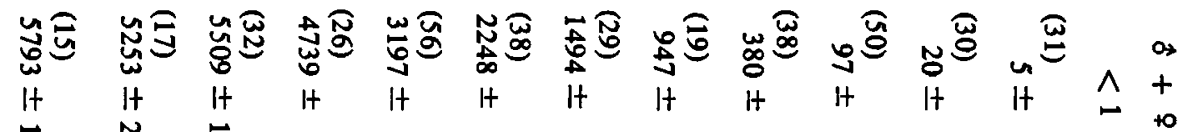
تิ

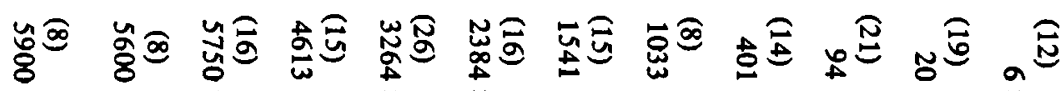
it $1+$ it it it it $H$ H

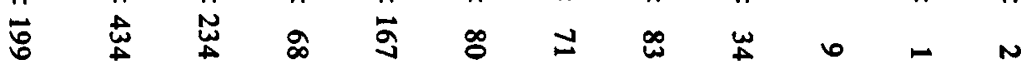

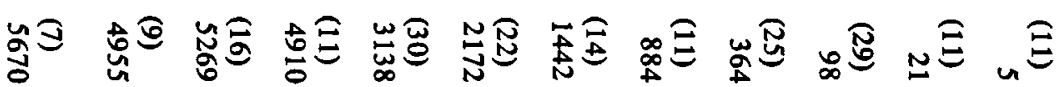
it it it it it it it it it it H it $1+0$

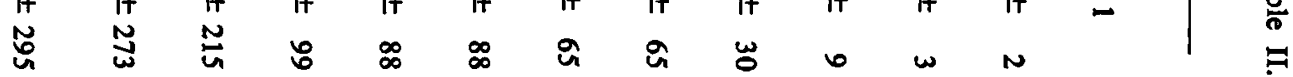

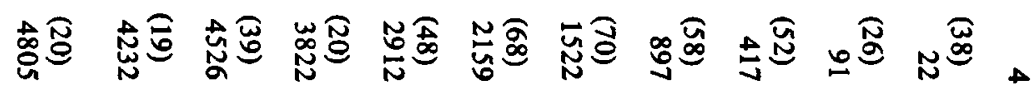
it it it it it it it it it it it it $\hat{2}+$

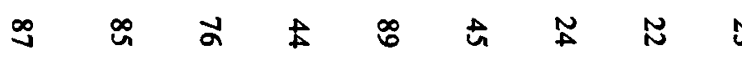

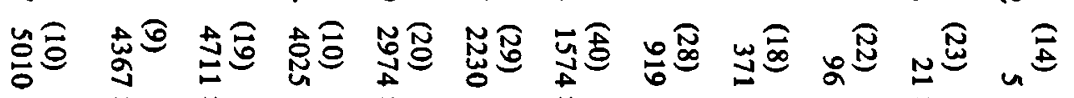
it It It H It it It H It H It H

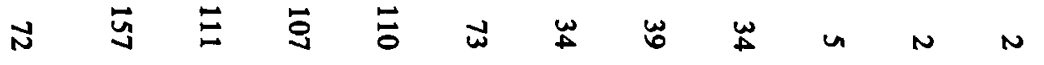

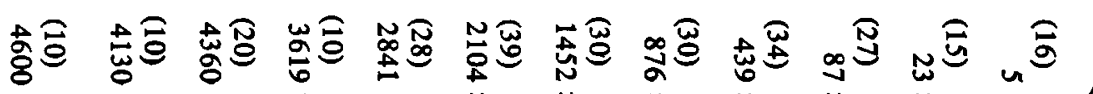

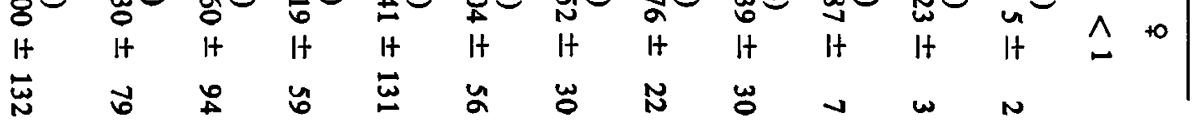
蓦它

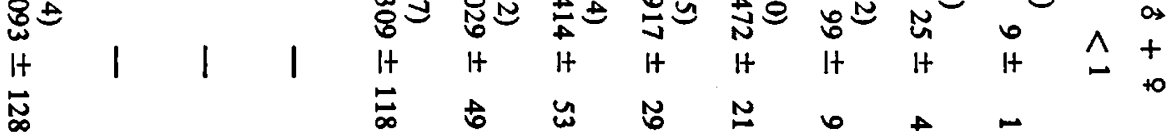

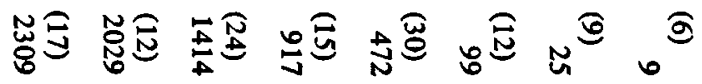
离 点 $\rightarrow$ W

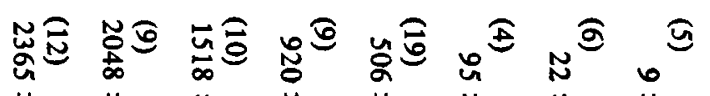

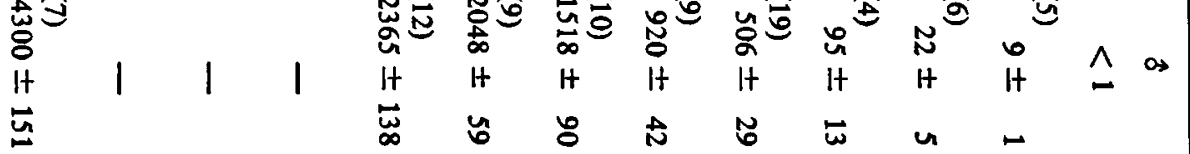
岕 $\underset{\substack{\infty \\ \infty}}{w}$

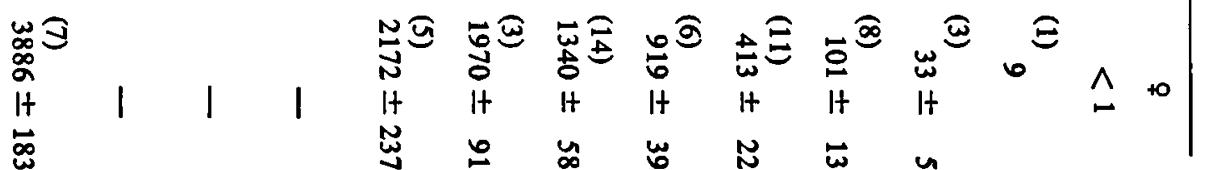




\section{§ 3.2 Growth and development of the placenta}

\section{$\S$ 3.2.1 Number of cotyledons}

The placentas of ruminants belong to the cotyledonary type according to Grosser's classification (1927). This type of placenta is characterized by the presence of dispersed islands of villi on the chorionic membrane. Each island contains a number of main stems together with their branches. These local accumulations of villi are called cotyledons. They are formed on those sites of the chorion which are situated opposite a socalled caruncle, which is a knotty elevation of the endometrium. The average number of caruncles in the left and right horns of the uterus together is about 100 (Alexander, 1964a). However, the number of fully developed cotyledons is, in most cases, less than 100. Their numbers can be rather variable; 60 to 100 according to Wimsatt (1950), 80 according to Alexander 1964a). The cotyledons have variable diameters, ranging from less than $0.5 \mathrm{~cm}$ to over $4 \mathrm{~cm}$ in extreme cases. As a rule their number shows an inverse relationship with their sizes: if there are many cotyledons their individual size is small; if there are relatively few cotyledons, their sizes can be increased in compensation. This has been dem- onstrated convincingly by experiments carried out by Alexander (1964b), who, in an experimental series of 40 sheep, removed a part of the caruncles by surgery.

Table III presents the average number of cotyledons per fetal sac found in the present investigation. It should be especially noted that the number of cotyledons in each case does not change during the course of pregnancy. There are significant differences between the numbers of cotyledons on the chorion of each fetus in single, twin and triplet pregnancies.

In the cases of single pregnancies there are about 70 cotyledons (table III). With regard to the question of whether or not these 70 cotyledons are spread evenly over the pregnant and the nonpregnant side, Alexander (1964a) states that the pregnant side contains more cotyledons than the non-pregnant side. Table III also gives the average numbers of cotyledons in the pregnant horn of singlets. These numbers do not differ substantially from the numbers of cotyledons in each horn in twin pregnancy (about 45). In single pregnancy there are about 15 to 20 cotyledons more, but these are found not in the pregnant, but in the non-pregnant horn.

In triplet pregnancy the situation is quite dif-

Table III. Mean numbers of fetal cotyledons per fetal sac (right column : per pregnant horn of a single fetus) $\pm 1 \times$ S.E.M. (The numbers of individuals are given in parentheses).

\begin{tabular}{|c|c|c|c|c|c|c|c|c|c|c|}
\hline \multirow[t]{2}{*}{ Group } & \multicolumn{3}{|c|}{ SINGLETS } & \multicolumn{3}{|c|}{ TWINS } & \multicolumn{3}{|c|}{ TRIPLETS } & \multirow{2}{*}{$\begin{array}{c}\text { SINGLETS } \\
\text { pregnant horn only } \\
\frac{\delta}{\delta}+q\end{array}$} \\
\hline & $\delta+q$ & ô & ㅇ & $\delta+q$ & $\hat{o}$ & $q$ & $\delta+q$ & $\hat{\delta}$ & $q$ & \\
\hline II & $\begin{array}{l}(17) \\
63 \pm 5\end{array}$ & $\begin{array}{l}(9) \\
70 \pm 3\end{array}$ & $\begin{array}{l}\text { (8) } \\
56 \pm 3\end{array}$ & $\begin{array}{l}(35) \\
44 \pm 4\end{array}$ & $\begin{array}{l}(13) \\
45 \pm 2\end{array}$ & $\begin{array}{l}\text { (9) } \\
35 \pm 3\end{array}$ & $\begin{array}{l}(6) \\
29 \pm 4\end{array}$ & $\begin{array}{l}(5) \\
31 \pm 5\end{array}$ & $\begin{array}{l}(1) \\
21\end{array}$ & $\begin{array}{l}(17) \\
42 \pm 2\end{array}$ \\
\hline III & $\begin{array}{l}\text { (27) } \\
63 \pm 3\end{array}$ & $\begin{array}{l}(17) \\
66 \pm 4\end{array}$ & $\begin{array}{l}(10) \\
58 \pm 6\end{array}$ & $\begin{array}{l}(45) \\
39 \pm 1\end{array}$ & $\begin{array}{l}(25) \\
39 \pm 2\end{array}$ & $\begin{array}{l}(20) \\
38 \pm 2\end{array}$ & $\begin{array}{l}\text { (9) } \\
25 \pm 3\end{array}$ & $\begin{array}{l}\text { (6) } \\
24 \pm 2\end{array}$ & $\begin{array}{l}\text { (3) } \\
28 \pm 9\end{array}$ & $\begin{array}{l}(27) \\
40 \pm 2\end{array}$ \\
\hline IV & $\begin{array}{l}(50) \\
59 \pm 3\end{array}$ & $\begin{array}{l}(22) \\
60 \pm 4\end{array}$ & $\begin{array}{l}(28) \\
58 \pm 4\end{array}$ & $\begin{array}{l}(54) \\
44 \pm 2\end{array}$ & $\begin{array}{l}(25) \\
41 \pm 2\end{array}$ & $\begin{array}{l}(29) \\
47 \pm 2\end{array}$ & $\begin{array}{l}(12) \\
36 \pm 3\end{array}$ & $\begin{array}{l}\text { (4) } \\
37 \pm 2\end{array}$ & $\begin{array}{l}(8) \\
36 \pm 4\end{array}$ & $\begin{array}{l}(50) \\
42 \pm 2\end{array}$ \\
\hline V & $\begin{array}{l}(37) \\
75 \pm 4\end{array}$ & $\begin{array}{l}(16) \\
74 \pm 7\end{array}$ & $\begin{array}{l}(21) \\
75 \pm 4\end{array}$ & $\begin{array}{l}(65) \\
49 \pm 2\end{array}$ & $\begin{array}{l}(24) \\
49 \pm 2\end{array}$ & $\begin{array}{l}(41) \\
49 \pm 2\end{array}$ & $\begin{array}{l}(30) \\
36 \pm 3\end{array}$ & $\begin{array}{l}(19) \\
34 \pm 3\end{array}$ & $\begin{array}{l}(11) \\
40 \pm 5\end{array}$ & $\begin{array}{l}(37) \\
48 \pm 2\end{array}$ \\
\hline VI & $\begin{array}{l}(17) \\
69 \pm 2\end{array}$ & $\begin{array}{l}\text { (6) } \\
69 \pm 2\end{array}$ & $\begin{array}{l}(11) \\
68 \pm 5\end{array}$ & $\begin{array}{l}(56) \\
46 \pm 2\end{array}$ & $\begin{array}{l}(27) \\
48 \pm 3\end{array}$ & $\begin{array}{l}\text { (29) } \\
43 \pm 2\end{array}$ & $\begin{array}{l}(15) \\
34 \pm 2\end{array}$ & $\begin{array}{l}\text { (9) } \\
34 \pm 3\end{array}$ & $\begin{array}{l}(6) \\
34 \pm 3\end{array}$ & $\begin{array}{l}(17) \\
45 \pm 2\end{array}$ \\
\hline VII & $\begin{array}{l}(27) \\
70 \pm 4\end{array}$ & $\begin{array}{l}\text { (14) } \\
71 \pm 5\end{array}$ & $\begin{array}{l}(13) \\
70 \pm 6\end{array}$ & $\begin{array}{l}(68) \\
45 \pm 1\end{array}$ & $\begin{array}{l}(36) \\
46 \pm 2\end{array}$ & $\begin{array}{l}(32) \\
44 \pm 2\end{array}$ & $\begin{array}{l}\text { (24) } \\
36 \pm 3\end{array}$ & $\begin{array}{l}(10) \\
35 \pm 4\end{array}$ & $\begin{array}{l}(14) \\
37 \pm 4\end{array}$ & $\begin{array}{l}(27) \\
48 \pm 2\end{array}$ \\
\hline VIII & $\begin{array}{l}(34) \\
69 \pm 3\end{array}$ & $\begin{array}{l}(14) \\
71 \pm 6\end{array}$ & $\begin{array}{l}(20) \\
68 \pm 4\end{array}$ & $\begin{array}{l}(69) \\
45 \pm 1\end{array}$ & $\begin{array}{l}(29) \\
45 \pm 2\end{array}$ & $\begin{array}{l}(40) \\
45 \pm 2\end{array}$ & 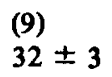 & $\begin{array}{l}\text { (6) } \\
33 \pm 3\end{array}$ & $\begin{array}{l}\text { (3) } \\
30 \pm 7\end{array}$ & $\begin{array}{l}(34) \\
45 \pm 2\end{array}$ \\
\hline IX & $\begin{array}{l}(51) \\
71 \pm 3\end{array}$ & $\begin{array}{l}(23) \\
72 \pm 5\end{array}$ & $\begin{array}{l}(28) \\
69 \pm 3\end{array}$ & $\begin{array}{l}(48) \\
47 \pm 2\end{array}$ & $\begin{array}{l}(21) \\
48 \pm 2\end{array}$ & $\begin{array}{l}(27) \\
47 \pm 2\end{array}$ & $\begin{array}{l}(12) \\
34 \pm 3\end{array}$ & $\begin{array}{l}\text { (7) } \\
39 \pm 3\end{array}$ & $\begin{array}{l}(5) \\
28 \pm 3\end{array}$ & $\begin{array}{l}(51) \\
47 \pm 2\end{array}$ \\
\hline $\mathbf{x}$ & $\begin{array}{l}(25) \\
66 \pm 4\end{array}$ & $\begin{array}{l}(15) \\
62 \pm 5\end{array}$ & $\begin{array}{l}(10) \\
72 \pm 6\end{array}$ & $\begin{array}{l}(19) \\
47 \pm 3\end{array}$ & $\begin{array}{l}(9) \\
43 \pm 3\end{array}$ & $\begin{array}{l}(10) \\
51 \pm 5\end{array}$ & $\begin{array}{l}(3) \\
20 \pm 5\end{array}$ & $\begin{array}{l}(2) \\
15\end{array}$ & $\begin{array}{l}(1) \\
30\end{array}$ & $\begin{array}{l}(25) \\
43 \pm 2\end{array}$ \\
\hline
\end{tabular}


ferent. In these cases there are three fetal sacs in the uterus. One horn contains two fetuses; as a rule the membranes of one of the fetuses extends partly into the horn which contains only one fetus. In these cases the total number of cotyledons equals the number of caruncles and may even be higher than 100 . So it seems that in twin and, especially, in single pregnancies a large proportion of possible sites are not occupied.

As distinct from the findings of Alexander (op. cit.), no significant difference is found between the numbers of cotyledons of male and female fetuses in the data presented here. This is true for single as well as for twin and triplet pregnancies.

\section{$\S$ 3.2.2 Growth of the fetal membranes}

The fetal membranes show a continuous increase until the end of pregnancy. In this section "weight of fetal membranes" denotes the combined weights of the chorionic, amniotic and allantoic membranes. Unlike man, the allantois is well developed in sheep. Table IV shows the increases in the weights of the membranes of singlets, twins and triplets. It appears that there are no significant differences between male and female fetuses.

As regards the distribution of the total amount of membranes over the pregnant and non-pregnant horns in single pregnancy, the following comments may be made. In groups II and III the ratio is $2: 1$ for the pregnant and the nonpregnant horn respectively. In later groups the weight increase of the membranes in the pregnant horn is faster, so that in group VI the ratio is $3: 1$ and in group $X$ it is even $4: 1$ in favour of the pregnant horn (see table IV, right column).
In fig. 7, A the weight increase of the membranes is presented graphically. It is quite clear that, on the average, a singlet has a greater amount of membrane than does the twin fetus. It should be pointed out that the total mass of the membranes in each pregnant uterus varies according to litter size. In fig. 7, B the total weight of membrane per uterus is plotted. From this figure it appears that the total combined weight of the membranes per uterus for twin and triplet pregnancies is, in group VIII, about twice and thrice the amount found in single pregnancy, respectively. At the end of multiple pregnancy the growth of the membranes slows down. The membranes in the only uterus in group $\mathrm{X}$ which contained triplets were extremely heavy; it should, however, be pointed out that only 3 fetuses from one uterus were dealt with, against 25 and 19 fetuses from single and twin pregnancies. The material included one case of quadruplets; the total weight of the membranes was equal to that in the case of triplet pregnancy in this group (465 grams).

The average weight of membranes which is accomodated in the sheep's uterus thus seems to be around 450 grams, although higher values are possible as is demonstrated in the case of triplet pregnancy in group $\mathrm{X}$ where the total weight of membranes was 710 grams.

\section{§ 3.2.3 Weight of the cotyledons}

The question of how the total mass of cotyledons increases as a function of time seems to be quite simple. However, a number of contradictory opinions are found in the literature. There is unanimous agreement as to the course in the

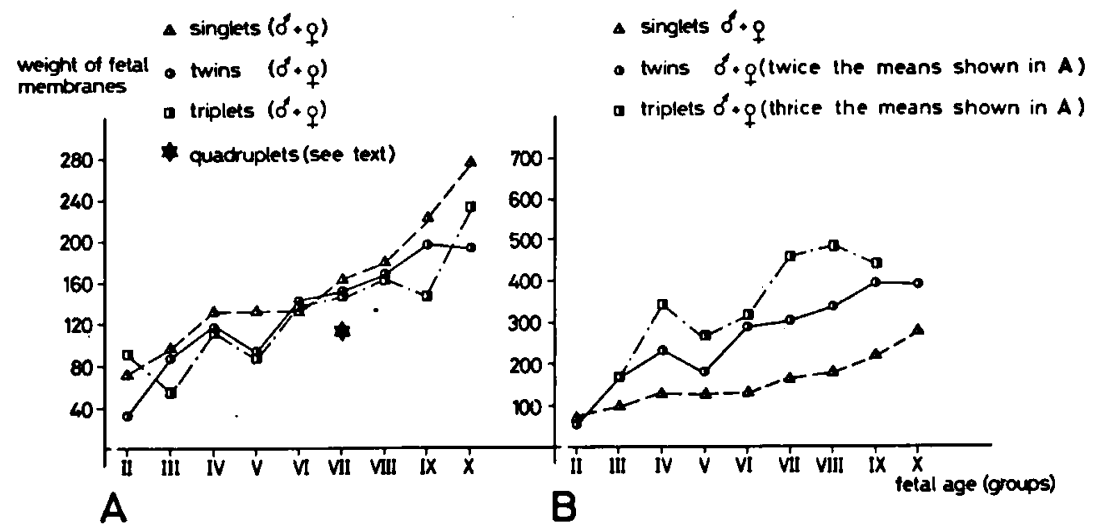

Fig. 7. A. Mean weight (in g) of fetal membranes per fetus.

B. Mean weight (in g) of fetal membranes per uterus. 


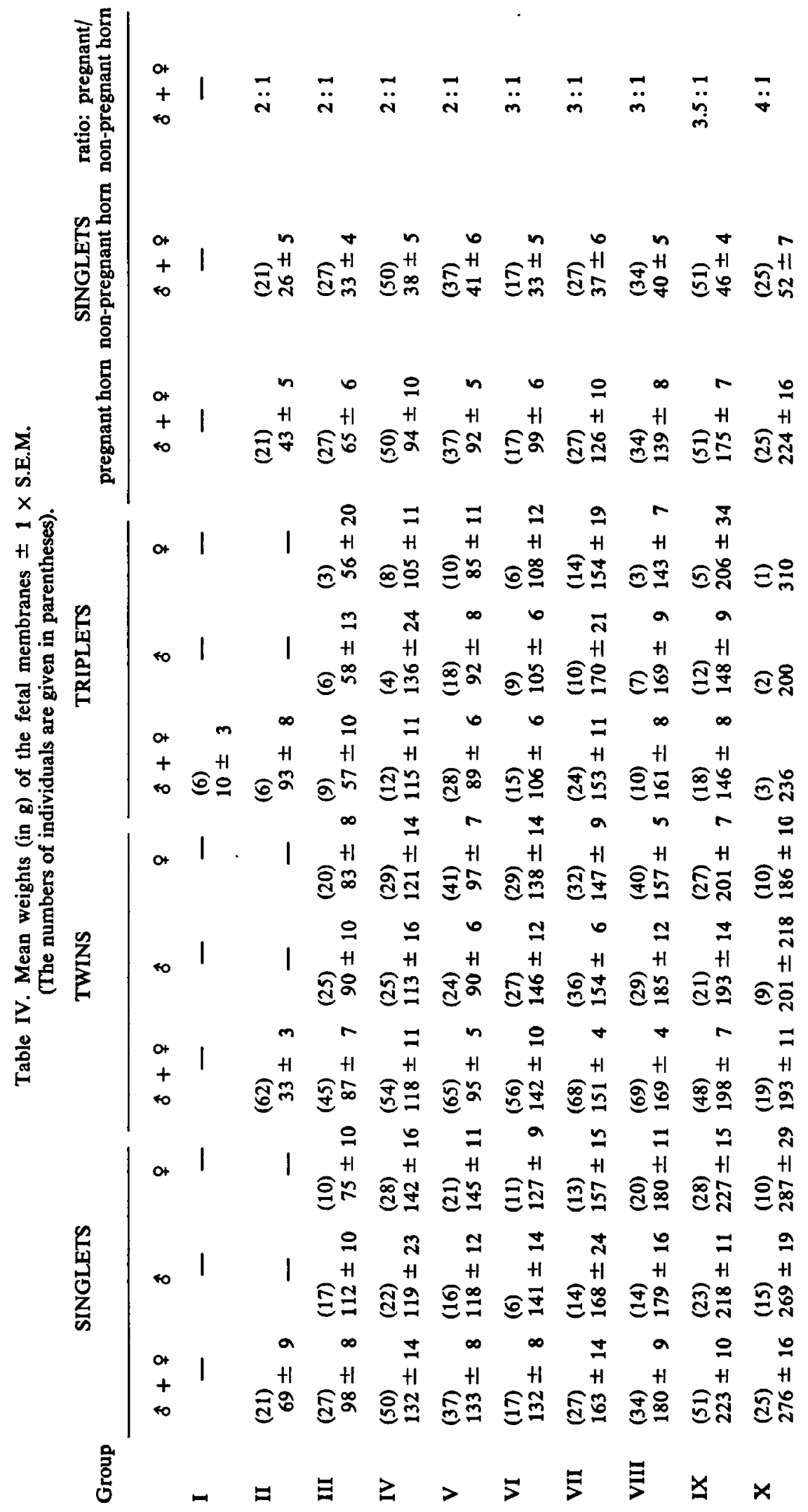


weight of cotyledonary mass

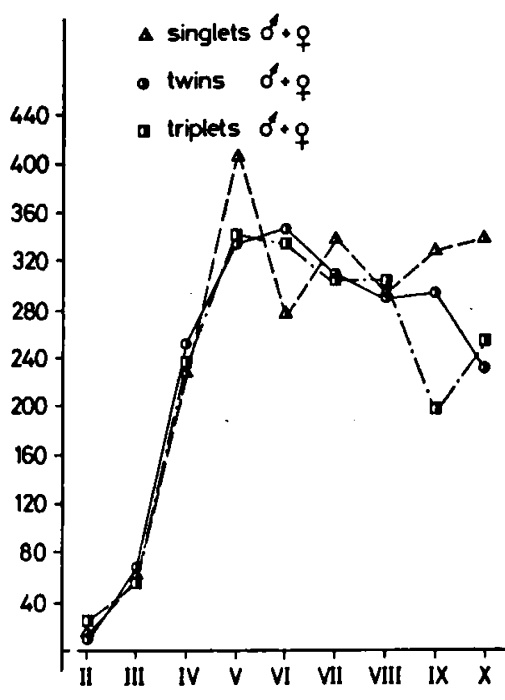

A

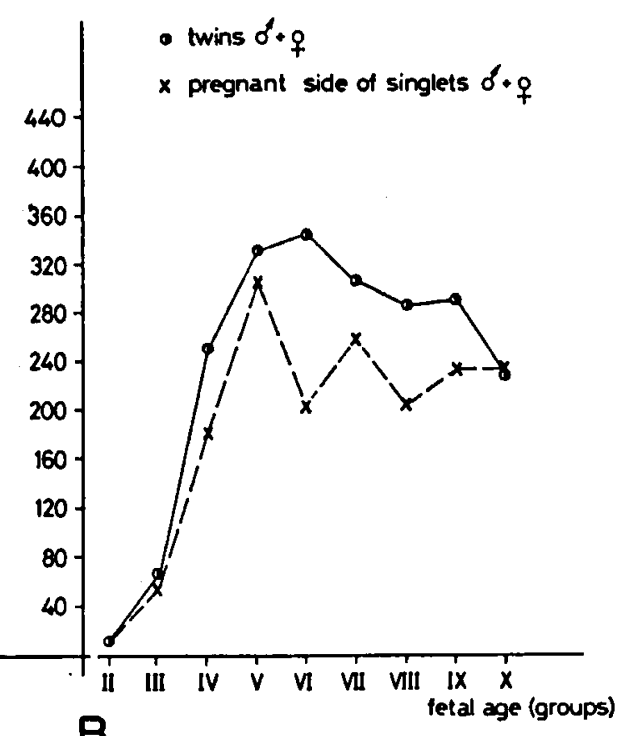

Fig. 8. Weight (in $g$ ) of total cotyledonary mass.

A. Singlets, twins and triplets compared.

B. The cotyledonary content in the pregnant horns of singlets and in the horns containing twins compared. first 90 days of pregnancy, the total length of which is about 145 days. The total weight of the cotyledons reaches its maximum after 80 to 90 days, which coincides with group V or VI in the present investigation (Barcroft \& Barron, 1946; Alexander, 1964a; Davies \& Wimsatt, 1966). From fig. 8, $\mathrm{A}$ it is apparent that, in the material presented here, for single and triplet pregnancies the maximum weight is reached in age group $\mathrm{V}$; in twin pregnancies the maximum weight is reached in group VI. The difference $-\mathrm{V}$ or VI -is not significant. Thus, for the total material it may be said that the maximum weight of the total cotyledonary mass is reached at the end of group V. In later stages the total weight of the cotyledons decreases, due to a decrease in the water content of the villi (Barcroft \& Barron, 1946); the mesenchymal component of the villi, which was considered to be analogous to Wharton's jelly, disappears gradually during ageing of the villi. This aspect will be discussed more extensively in $\S$ 4.1. From fig. 8, A the conclusion seems to be warranted that the decrease in weight in multiple pregnancies is sharper than in single pregnancies. This agrees with the findings of Barcroft \& Kennedy (1939). It would seem from table $\mathrm{V}$ and fig. 8, A that this effect is even more pronounced in triple pregnancies than in twins. It should be pointed out however, that though the values in the case of triplet pregnancy in group $X$ are higher than those for twins, these high values refer to only 1 uterus containing 3 fetuses against 10 uteri in which twins were present. Our findings are in contrast to Alexander's (1964a), who described a decrease in total cotyledonary weight occurring between day 90 and day 135 in single pregnancies also; in twin pregnancies however, he observed an increase.

The total weight of the cotyledons from one of twin fetuses is higher than that found in the pregnant horn of a singlet (fig. 8, B, table V). This at first sight seems difficult to understand, since the numbers of cotyledons are equal ( $\$$ 3.2.1). It should be borne in mind, however, (Alexander, 1964a) that the average weight of the individual cotyledons in twin pregnancies is higher than that of a singlet. Nevertheless, the total mass of cotyledons of a singlet is heavier than that of the individual twins. This results from the fact that, in the case of single pregnancy, extra cotyledons can be formed in the non-pregnant horn.

The finding that in twin pregnancies the weight decrease of the total cotyledonary mass during the last weeks is substantially greater than in the cases of single pregnancies (Barcroft \& Kennedy, 1939) explains why the weight of the placenta in single pregnancies in the pregnant horn is more or less equal to the weight of the placenta of twins.

At variance with results of Alexander it can be concluded from table $\mathrm{V}$ that in the present material there are no significant differences in total mass of cotyledons between male and female pregnancies; this is true both for single, twin and triplet pregnancies. 


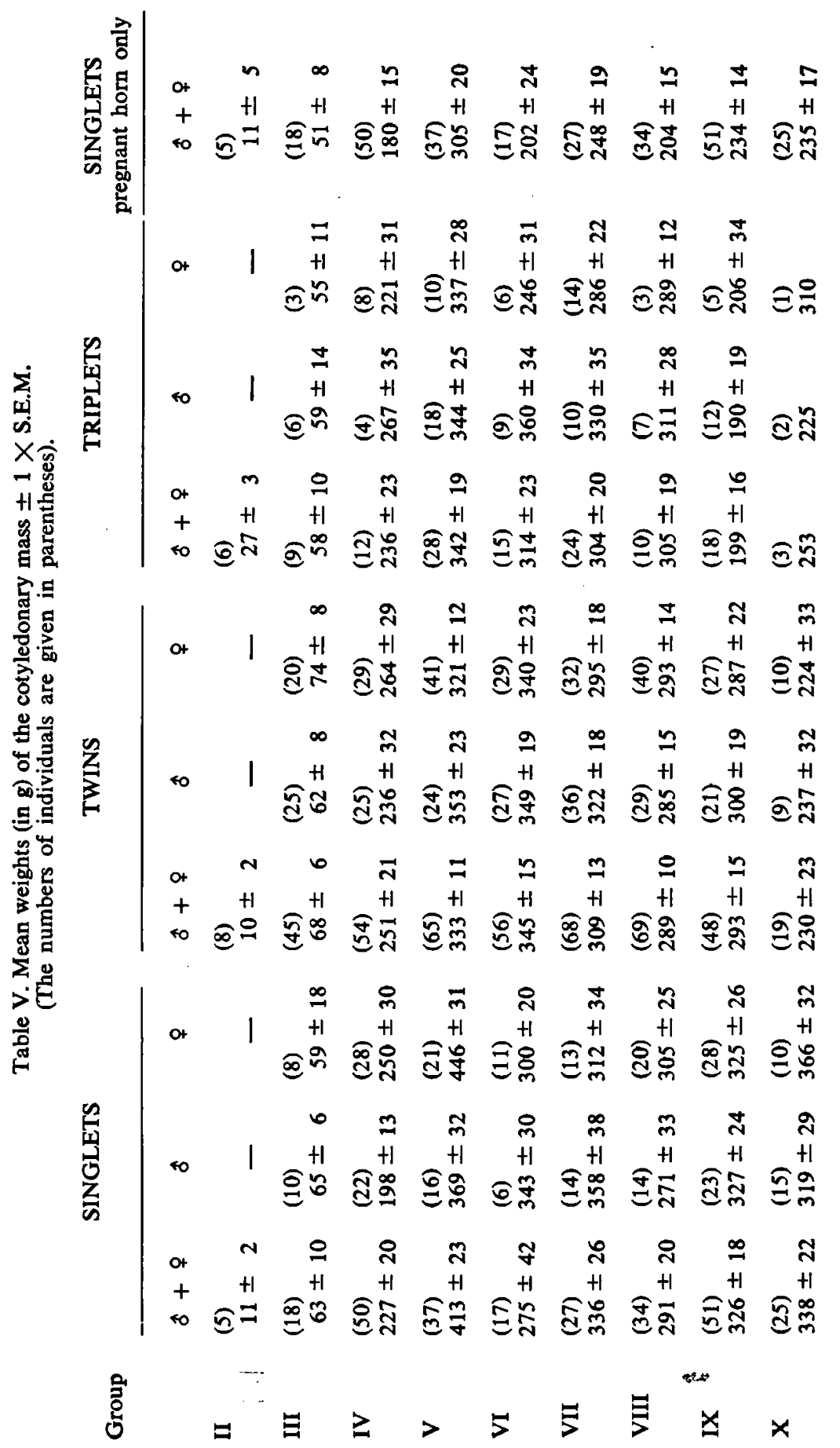




\section{$\S 3.3$ Growth of the uterus}

\section{§ 3.3.1 Macroscopic observations}

It is a well established fact that a mutual relationship exists between the uterus and the conceptus. The measure to which the contents can develop depends on the volume of the uterus, as was shown by the experiments of Walton \& Ham. mond (1938).

On the other hand, two kinds of factors are supposed to be responsible for the uterine changes in pregnancy. First there are hormonal stimuli originating in the ovaries, placenta and fetal adrenals (Braun \& Mosler, 1970; Hoff \& Baier, 1952; Richter \& Götze, 1950). The second type of stimulus is a mechanical one, related to the increasing volume of the conceptus (Braun \& Mosler, 1970; Hoff \& Baier, 1952; Reynolds, 1949). When the conceptus reaches a certain volume it exerts pressure; this pressure results in a local stretching, a factor which functions as a growth-promoting stimulus. These considerations make it plausible that in the uterus of the sheep differences in growth will occur, depending on the number of fetuses. Table VI presents data on the weight increase of the horns of the uterus for different groups. In singlet pregnancies the pregnant and the non-pregnant horns were weighed separately. In triplet pregnancies a distinction was made between the horn containing one fetus and the horns containing two fetuses. Fig. 9. A gives the curves of the total weight of the uterus in singlets, twins and triplets, respectively. As was to be expected, the total weight of the uterus depends on the number of fetuses.

In fig. 9, B the mean weights of the pregnant horns containing one fetus are plotted. In the case of the singlets this of course means the weight of the pregnant horn. As regards the twin pregnancies, both horns could be used because both horns contained one fetus (the exceptional cases in which the two fetuses of a twin pregnancy were located in one horn were not included).

In the case of the triplet pregnancies only the horns containing one fetus were included. In the first place it appears that, in the case of twin pregnancy, the growth of the horns shows a rather continuous course. The horn in which the fetus of singlet pregnancy is present follows a somewhat different course. It shows a weight increase, until group $\mathrm{V}$, of the same order as that found in twin pregnancies. This could be explained by the fact that the two types of horn initially contain about the same amount of chorion;

Table VI. Mean weights (in $g$ ) of the uterine horns $\pm 1 \times$ S.E.M.

(The numbers of horns are given in parentheses).

\begin{tabular}{|c|c|c|c|c|c|}
\hline Group & $\begin{array}{l}\text { TWINS } \\
\hat{o}+\stackrel{+}{\text { pregnant }}\end{array}$ & $\begin{array}{r}\text { SINC } \\
\text { of } \\
\text { pregnant } \\
\text { side }\end{array}$ & $\begin{array}{l}\text { HLETS } \\
+\quad \text { \& } \\
\text { non-pregnant } \\
\text { side }\end{array}$ & $\begin{array}{r}\text { TRIPLE } \\
\hat{\alpha}+ \\
\text { horn with } \\
\text { two fetuses }\end{array}$ & $\begin{array}{l}\text { ETS } \\
0 \\
\text { horn with } \\
\text { one fetus }\end{array}$ \\
\hline II & $\begin{array}{l}(59) \\
67 \pm 9\end{array}$ & $\stackrel{(28)}{64 \pm 5}$ & $\begin{array}{l}(34) \\
50 \pm 3\end{array}$ & $\begin{array}{l}(2) \\
149 \pm 9\end{array}$ & $\begin{array}{l}(2) \\
140 \pm 13\end{array}$ \\
\hline III & $\begin{array}{l}(38) \\
148 \pm 10\end{array}$ & $\begin{array}{l}(29) \\
121 \pm 8\end{array}$ & $\stackrel{(31)}{72} \pm 4$ & $\begin{array}{l}(3) \\
220 \pm 35\end{array}$ & $\begin{array}{l}(3) \\
170 \pm 33\end{array}$ \\
\hline IV & $\begin{array}{l}(50) \\
280 \pm 18\end{array}$ & $\begin{array}{l}(45) \\
235 \pm 13\end{array}$ & $\begin{array}{l}(46) \\
107 \pm 7\end{array}$ & $\begin{array}{l}(4) \\
413 \pm 44\end{array}$ & $\begin{array}{l}(4) \\
334 \pm 44\end{array}$ \\
\hline V & $\begin{array}{l}(52) \\
342 \pm 12\end{array}$ & $\begin{array}{l}(35) \\
340 \pm 19\end{array}$ & $\begin{array}{l}(35) \\
176 \pm 10\end{array}$ & $\begin{array}{l}(10) \\
513 \pm 32\end{array}$ & $\begin{array}{l}(10) \\
391 \pm 40\end{array}$ \\
\hline VI & $\begin{array}{l}(56) \\
366 \pm 11\end{array}$ & $\begin{array}{l}(15) \\
300 \pm 16\end{array}$ & $\begin{array}{l}(15) \\
156 \pm 14\end{array}$ & $\begin{array}{l}(5) \\
469 \pm 45\end{array}$ & $\begin{array}{l}(5) \\
366 \pm 40\end{array}$ \\
\hline VII & $\begin{array}{l}(68) \\
385 \pm 9\end{array}$ & $\begin{array}{l}(28) \\
359 \pm 18\end{array}$ & $\begin{array}{l}(28) \\
147 \pm 12\end{array}$ & $\begin{array}{l}\text { (8) } \\
571 \pm 34\end{array}$ & $\begin{array}{l}(8) \\
449 \pm 29\end{array}$ \\
\hline VIII & $\begin{array}{l}(66) \\
432 \pm 13\end{array}$ & $\begin{array}{l}(36) \\
371 \pm 12\end{array}$ & $\begin{array}{l}(34) \\
194 \pm 9\end{array}$ & $\begin{array}{l}\text { (4) } \\
632 \pm 28\end{array}$ & $\begin{array}{l}(4) \\
486 \pm 25\end{array}$ \\
\hline IX & $\begin{array}{l}(48) \\
491 \pm 18\end{array}$ & $\begin{array}{l}(55) \\
424 \pm 15\end{array}$ & $\begin{array}{l}(54) \\
201 \pm 8\end{array}$ & $\begin{array}{l}(6) \\
517 \pm 31\end{array}$ & $\begin{array}{l}(6) \\
481 \pm 15\end{array}$ \\
\hline $\mathbf{X}$ & $\begin{array}{l}(14) \\
506 \pm 32\end{array}$ & $\begin{array}{l}(26) \\
551 \pm 28\end{array}$ & $\begin{array}{l}(26) \\
273 \pm 17\end{array}$ & $\begin{array}{c}(1) \\
1100\end{array}$ & $\begin{array}{l}(1) \\
470\end{array}$ \\
\hline
\end{tabular}




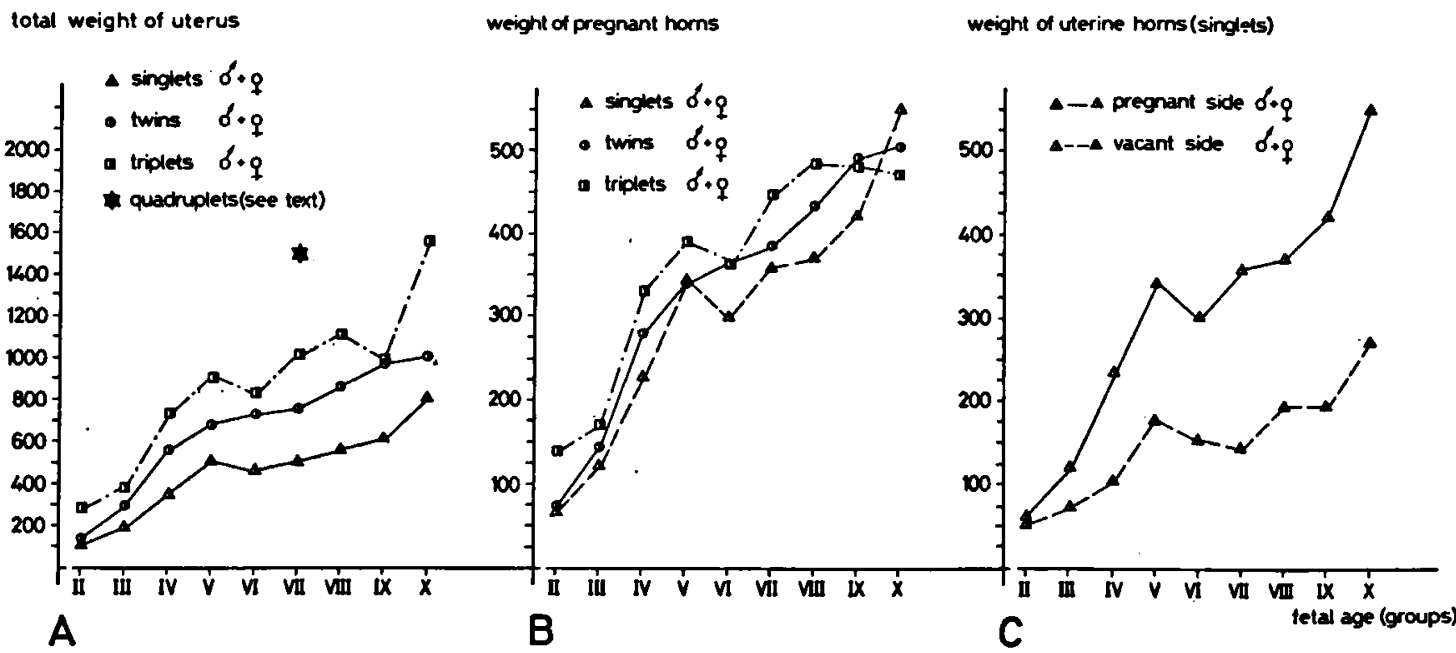

Fig. 9. A. Mean weight (in $\mathrm{g}$ ) of the total uterus (both horns). Singlets, twins and triplets compared.

B. Mean weight (in $\mathrm{g}$ ) of pregnant horns, each containing one fetus. Singlets, twins and triplets compared.

C. Weight (in g) of uterine horns in singlets. Difference between pregnant and non-pregnant horns.

as a consequence, the amount of growth stimulation is about equal in the two instances. In the second half of pregnancy both the fetus and the amount of amniotic fluid increase in volume. However, in a singlet pregnancy a large part of the allantoic fluid can be accomodated in the nonpregnant horn. Consequently the pressure exerted on the pregnant horn by the volume of the contents will be smaller in the case of singlet pregnancy than in the case of twin pregnancies, where both horns contain a conceptus. Consequently, in the pregnant horn of the singlet pregnancy the contents will exert a smaller growth-stinlulating influence than in the case of twin pregnancy. At an early stage of triplet pregnancy there will be a large amount of chorionic tissue present in the uterus; it therefore seems plausible that the uterus will be stimulated to a still higher degree than in the case of twin pregnancy. This supposition is in accordance with the course of the weight increase of the uterus containing triplets. Although in one of the horns only one fetus is present, it should be kept in mind that in a case of triplet pregnancy this horn also contains part of the fetal membranes and fluids belonging to one of the fetuses present in the other horn.

From the curves in fig. 9, $B$ it appears that the growth between groups $\mathrm{V}$ and VII in all three types shows a less steep increase or even a decline. As mentioned earlier, there are reasons to suppose that different impulses stimulate growth of the uterus in the course of pregnancy; in the early phase there is a stimulus exerted by the placental hormones but in later phases the stimulus is mostly a mechanical one exerted by the uterine contents. If this pressure builds up rather late, this could explain the transient decrease in weight. This explanation would especially be valid for singlet pregnancy where part of the uterine contents can escape into the second horn, a possibility which does not exist in twin and triplet pregnancies. From table VI and fig. 9, C it is apparent that the nor-pregnant horn of the singlet pregnancy does not increase in weight again (after the increase in groups I through IV) earlier than group VIII. Apparently it is not until this stage of development that the uterine contents, consisting of membranes plus amniotic and allantoic fluids, have sufficient volume to function as a growth stimulus.

Fig. 9, C shows the difference in growth between the pregnant and non-pregnant horns in singlet pregnancies. The non-pregnant horn eventually attains half the weight of the pregnant horn. The non-pregnant horn also grows rather rapidly until group $\mathrm{V}$, though less so than the pregnant horn. It is after group $\mathrm{V}$ that the fetus shows its steep increase in weight. However, it is plausible to find that the growth of the preg. nant horn shows a continuous course, with the non-pregnant horn lagging behind.

It should be mentioned that in the cow, in which multiple pregnancies are very exceptional, a 
difference in weight between the pregnant and non-pregnant horns has also been described (Abdel-Raouf \& El-Naggar, 1969).

\section{$\S$ 3.3.2 Differentiation of the caruncles. Micro- scopic data}

Within the caruncle the villi and maternal septa interdigitate. These septa are covered by a syncytium, the origin of which is the subject of a still continuing discussion. Depending on the different views on the origin of this syncytium, the placenta of the sheep is classified in different ways. If the syncytium is considered as being of fetal origin (Wimsatt, 1950; Davies \& Wimsatt, 1966), the placenta is classified as syndesmochorial according to Grosser's classification (1927). If, on the other hand, it is assumed that the syncytium is of maternal origin, (Ludwig, 1962; Björkman 1965: 1970), then the sheep's placenta belongs, as does the cow's placenta, to the epithelio chorial type. Without entering into the details of these discussions, a study was made of the development of the blood vessels in the maternal component of the placentoma. In each placentoma 1000 points were counted as described in $\$ 2.3 .1$. The degree of vascularization of the caruncles was expressed in the following arbitrary units: (number of points counted in maternal blood vessels) divided by (number of points counted in maternal blood vessels + maternal tissue).

As regards the growth of the caruncular tissue, far less is known about this than about the growth of the fetal component. Alexander (1964a) has stated that in each caruncle the maternal component is more extensive than the fetal component. He found an average ratio of $2: 3$ between the fetal and maternal parts of the placentomas. He carried out his determinations on 26 single pregnancies, all on day 146 of pregnancy; day 146 corresponds with the end of group $X$ in the present material. Wallace (1948), however, reached quite a different conclusion. These latter findings agree with the data presented in table VII. This table shows the distribution of maternal and fetal counts per 1000 . The table gives the quotient: (average number of points counted in the maternal tissue) divided by (average number of points counted in the fetal tissue). The values in this table show that in all groups there is considerably less maternal tissue than fetal tissue. These microscopic data agree with the macroscopic data presented by Wallace (1948). From table VII it can further be taken that there is a special predominance of fetal tissue in groups IV and V. The decrease from group III to group IV is caused by a marked increase in the volume of the villi during this period. When in a later phase these plump villi differentiate into finely branched complexes, the uterine component has to follow these branches by penetrating between the newly formed branches. At the same time, the placenta looses weight due to decreased water content and to decreases in the amount of young connective tissue in the villi. These two factors give rise to both an absolute and a relative increase of the maternal part going from group $\mathrm{V}$ to VI. It is plausible to find that the uterine component does not develop any further with respect to branching as soon as the villi are completely differentiated. This stage is reached around age group VII as will be mentioned in $\S$ 4.1.

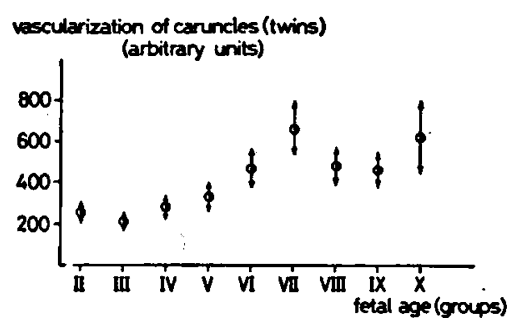

Fig. 10. Degree of vascularization of caruncles. Arbitrary units as described in $\$ 2.3 .1$.

Fig. 10 shows that the degree of vascularization of the caruncles increases by a factor 2 to 3 between group II to VI or VII. It even seems that a decrease of vascularization occurs in groups VIII and IX (fig. 10). Although this decrease is not statistically significant, such a decrease would fit in well with a number of observations mentioned below. It cannot be excluded that a real transient decrease of uterine vessels occurs in these groups. It is worth mentioning that in

Table VII. Quotients : mean of maternal tissue counts/mean of fetal tissue counts. (The numbers of individuals are given in parentheses).

$\begin{array}{lllllllll}\text { Group } & \text { III } & \text { IV } & \text { V } & \text { VI } & \text { VII } & \text { VIII } & \text { IX } & \text { X } \\ \text { TWINS } & (32) & (30) & (32) & (48) & (37) & (34) & (39) & (14) \\ & 0.6765 & 0.4432 & 0.4613 & 0.6636 & 0.6636 & 0.6762 & 0.6622 & 0.7293\end{array}$


histological slides of groups VIII and IX the vessels in the maternal part often appear to be collapsed, so that they are difficult to discern. Furthermore, it should be noted that in fig. 17 (see there) it also appears that the degree of vascularization of the villi shows a less steep increase in groups VIII and IX than in other groups. It can be speculated that at this moment some unknown factor causes a collapse of a number of the blood vessels both in the fetal and in the maternal part. Since the blood vessels in the uterine component no longer proliferate, such a collapse should lead to a decrease during this period. Such a decrease does not occur in the fetal vessels because they are still enlarging.

CHAPTER 4. RESULTS. THE MICROSCOPIC DIFFERENTIATION OF THE PLACENTA IN TWIN PREGNANCY

\section{$\S 4.1$ Branching of the villi. Introduction}

At about the fourth week of pregnancy villi begin to differentiate from the chorionic membrane. At those sites where chorionic tissue is situated opposite uterine caruncles, folds of chorion form. These folds are covered with chorionic epithelium; they enlarge and from primary villi. At a somewhat later stage the tops of these villi branch, forming second-order villi. At a still later stage third-order villi arise at about right angles from the second-order villi. A more detailed description is given by Wimsatt (1950). Wimsatt's description cannot be applied directly to the present material, since in the present study another classification of age groups is used. Wimsatt had at his disposal animals in which the dates of fertilization were known exactly. In the present material, obtained from the slaughterhouse, this was not the case. The differentiation of the villi is illustrated in figs. 11 and 12, printed with the same magnification ( $X 20$ ). In group II (fig. 11, A and B) the villi have a very simple structure; they are loosely attached to the maternal tissue (fig. 11, A). It is quite difficult at this stage to excise the placentoma as a whole without disturbing the relation between maternal and fetal tissues. Often the villi loosen themselves spontaneously from the caruncles when the uterus is cut open (fig. 11, B). When dealing with a pregnancy in stage $\mathrm{II}$, it was necessary to proceed as follows. Before the uterus was cut open, the am- niotic fluid was removed by a small incision through the wall of the uterus and the membranes. When the uterus was subsequently cut open it proved possible to keep the cotyledons in situ. The opened uterus was fixed, together with the chorionic membrane, on a piece of cork by means of many pins. Then, a $12 \%$ formalin solution was poured over the preparation. Thus in a number of cases it was possible to excise the placentoma without pulling the cotyledonary villi out of the caruncle.

Further treatment of the piece of tissue obtained in this way had to be very careful, and even after all precautions were taken it often appeared that the cotyledon had detached from the caruncle.

This problem is only met in group II. At later stages the villi enlarge and become much longer. These changes are illustrated in fig. 11, C and $D$, both taken from a placenta in group V. Fig. 11, D shows two hematomas. These extravasations of maternal blood begin to form at about age group III. As pregnancy proceeds they become bigger, but are always restricted to the subchorial plate of the placentomas. These hematomas are fundamentally different from the blood in the intervillous spaces in the human placenta. In sheep the maternal blood does not circulate, but the erythrocytes are absorbed by the columnar trophoblastic epithelium cells, which are very elongated in this region. (See also Drieux \& Thiéry, 1952 and Davies \& Wimsatt, 1966).

A great mass of embryonic connective tissue is present in the villi. Barcroft \& Barron (1946) consider this stroma to be structurally identical with Wharton's jelly, present in the umbilical cord. According to their description, this tissue is largely broken down starting from the 80th day. Eventually the villi with their branchings are reduced to thin strands of connective tissue containing blood vessels and surrounded by a simple epithelium. This state of affairs, described by Wimsatt (1950), was confirmed in the present study. Fig. 12, A (stage VII) and fig. 12, B (stage $\mathrm{X})$ clearly illustrate the differentiation of the villi. It appears from these illustrations that as regards branching of the villi the situation does not change after group VII. In areas close to the chorionic plate the main stems often contain a small amount of mesenchymal tissue; the greater part of the villi, however, are reduced to thin strands. The loss of placental weight described by Barcroft \& Barron (1946) after 90 days can, to a large extent, be explained by the loss of water which 


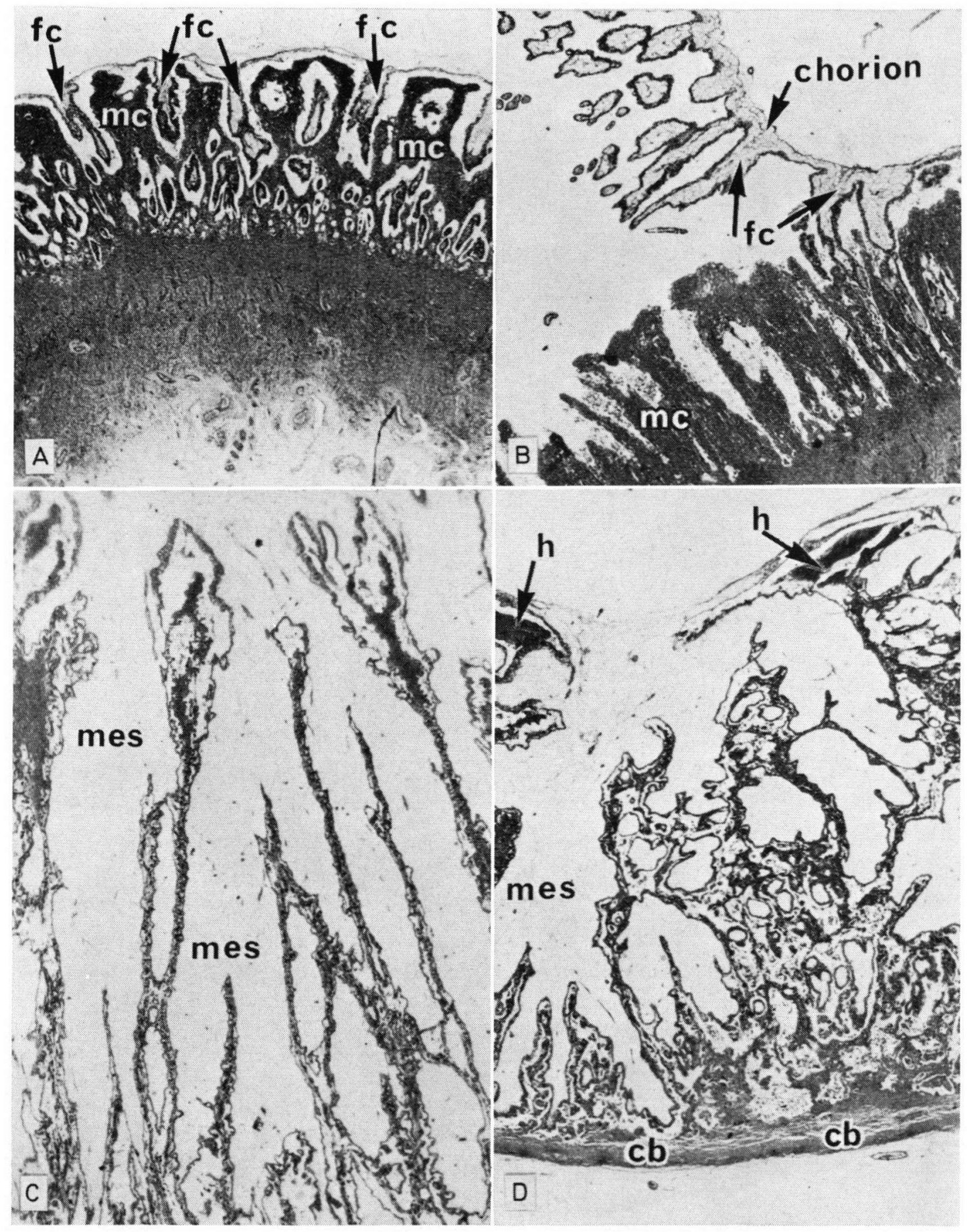

Fig. 11. A. Part of a placentoma in group II $(X 20)$ with ingrowing villi.

B. A site of a placentoma in group II $(X 20)$ where villi have been torn out of the maternal crypts in the course of processing.

C. Early placentoma in group V $(\times 20)$. The villi have reached about their maximum length and are still very plump.

D. Late placentoma in group $V(\times 20)$. The villi are beginning to differentiate, branching starting at the tops of the villi.

For abbreviations, see $\$ 2.3 .3$. 


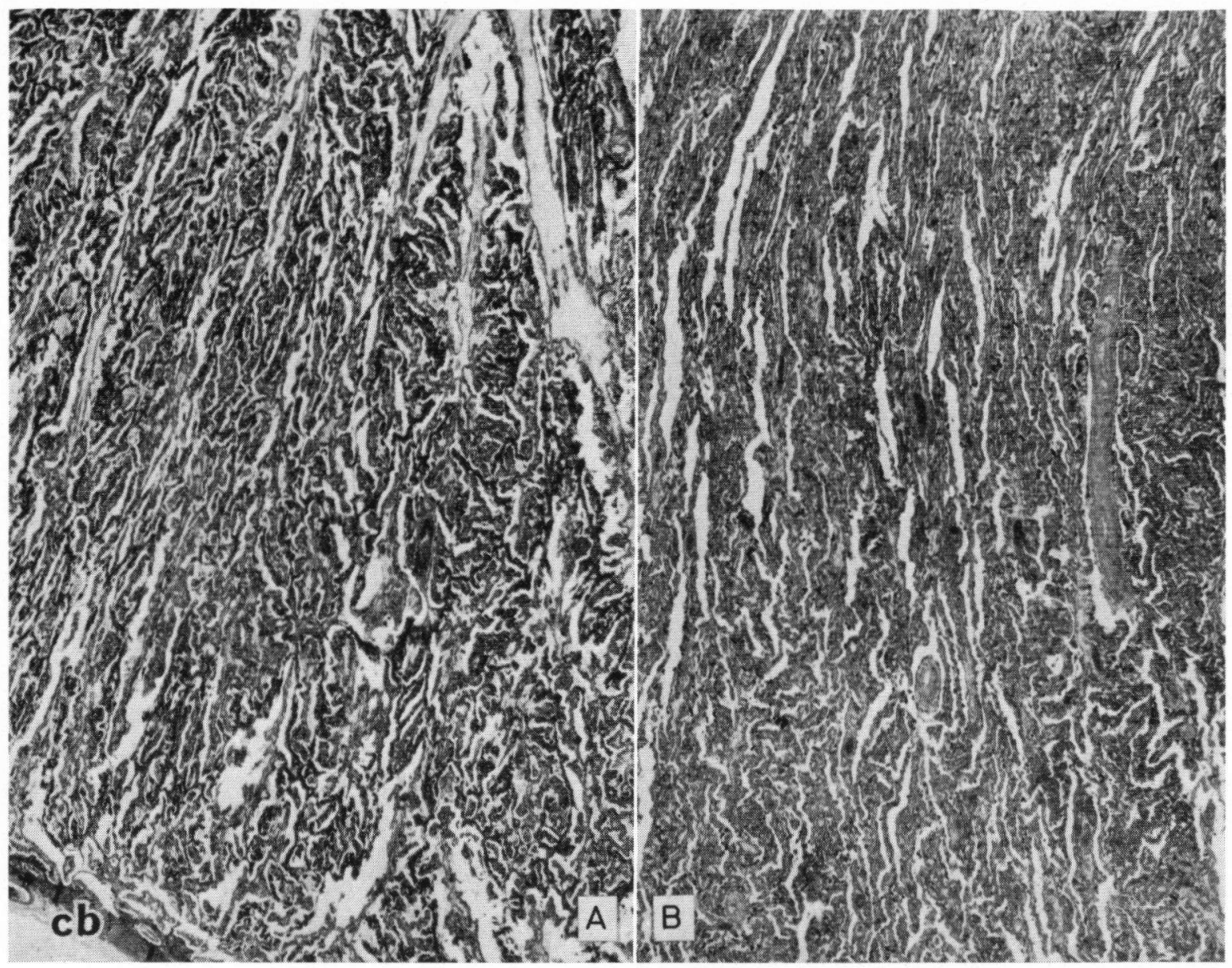

Fig. 12. A. Placentoma group VII $(\times 20)$. Almost all of the mesenchymal tissue has disappeared. The white spaces in both micrographs $A$ and $B$ are mostly artificial spaces caused by shrinkage.

B. Placentoma group X $(\times 20)$. This placentoma shows the same characteristics as that in group VII. A comparison of $\mathrm{A}$ and $\mathrm{B}$ shows no apparent difference in the degree of branching of the villi.

accompanies the disappearance of the hydrophilic stroma.

This qualitative description was supplemented with quantitative data concerning the development of the branching pattern (see $\S 4.2$ ).

\section{$\S 4.2$ Quantification of the villous branching}

Table VIII summarizes the average values for the degree of branching per age group. As regards the methodology and arbitrary units used, the reader is referred to chapter 2 . For reasons given in chapter 1 , only the situation in twin pregnancies will be dealt with in this section. Another reason for this restriction was that only the group of twin pregnancies contained sufficient material to warrant conclusions with a reasonable degree of certainty. Possible differences between single, twin and triple pregnancies will be dealt with in a separate chapter (6).

Fig. 13 shows that there is an apparent initial fall in the degree of branching after group II. It has to be kept in mind, however, that the degree of branching as defined in the present context is determined by the number of counts per field of view. When comparing fig. 11, A and $B$ with $C$ and $D$, all presented with the same magnification, it is clear indeed that in fig. 11, A and $B$ more points of sectioning with fetal villi are present than in the pictures $C$ and $D$. In these lower groups, however, the term "degree of branching" is misleading since this term does not denote the real degree of branching but rather is a reflection of the large number of very small villi. The villi do branch already, but the increase in the degree of branching is masked by the over- 
Table VIII. Degree of branching of placental villi $\pm 1 \times$ S.E.M. expressed in arbitrary units (see text).

(The numbers of individuals are given in parentheses).

\begin{tabular}{|c|c|c|c|c|c|c|c|c|c|}
\hline Group & II & III & IV & V & VI & VII & VIII & IX & $\mathbf{x}$ \\
\hline $\begin{array}{l}\text { SINGLETS } \\
\text { pregnant } \\
\text { horn }\end{array}$ & $\begin{array}{l}\text { (5) } \\
\quad 0.0936 \\
\pm 0.0150\end{array}$ & (5) $\begin{array}{r}0.0505 \\
\pm 0.0052\end{array}$ & (7) $\begin{array}{r}0.0463 \\
\pm 0.0045\end{array}$ & $\begin{array}{l}\text { (5) } \\
0.0522 \\
\pm 0.0089\end{array}$ & $\begin{array}{l}\text { (6) } \\
0.1217 \\
\pm 0.0110\end{array}$ & $\begin{array}{l}\text { (5) } \\
0.1447 \\
\pm 0.0221\end{array}$ & $\begin{array}{r}\text { (14) } \\
0.2289 \\
\pm 0.0057\end{array}$ & $\begin{array}{l}\text { (15) } \\
\quad 0.1938 \\
\pm 0.0154\end{array}$ & 一 \\
\hline $\begin{array}{l}\text { SINGLETS } \\
\text { non-pregnant } \\
\text { horn }\end{array}$ & & $\begin{array}{l}\text { (4) } \\
\quad 0.0611 \\
\pm 0.0057\end{array}$ & $\begin{array}{l}\text { (8) } \\
0.0493 \\
\pm 0.0028\end{array}$ & (4) $\begin{aligned} & \\
& 0.0498 \\
&+0.0065\end{aligned}$ & 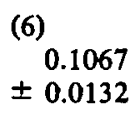 & 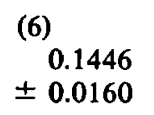 & $\begin{array}{l}\text { (13) } \\
\quad 0.2156 \\
+0.0104\end{array}$ & $\begin{array}{l}\text { (14) } \\
\quad 0.2065 \\
\pm 0.0062\end{array}$ & - \\
\hline TWINS & $\begin{array}{l}\text { (18) } \\
0.0927 \\
\pm 0.0081\end{array}$ & $\begin{array}{l}(30) \\
\quad 0.0576 \\
\pm 0.0025\end{array}$ & $\begin{array}{l}\text { (26) } \\
0.0507 \\
\pm 0.0039\end{array}$ & $\begin{array}{l}(30) \\
0.0872 \\
+0.0062\end{array}$ & $\begin{array}{l}(30) \\
\quad 0.1542 \\
\pm 0.0051\end{array}$ & $\begin{array}{l}(30) \\
0.1890 \\
\pm \quad 0.0073\end{array}$ & $\begin{array}{l}\text { (34) } \\
\quad 0.2012 \\
\pm \quad 0.0052\end{array}$ & $\begin{array}{l}(30) \\
0.1843 \\
\pm 0.0045\end{array}$ & $\begin{array}{l}\text { (14) } \\
0.1964 \\
\pm 0.0076\end{array}$ \\
\hline TRIPLETS & 一 & $\begin{array}{l}\text { (9) } \\
\quad 0.0660 \\
\pm 0.0104\end{array}$ & $\begin{array}{l}(6) \\
\quad 0.0670 \\
\pm 0.0081\end{array}$ & $\begin{array}{l}\text { (11) } \\
0.0823 \\
\pm 0.0052\end{array}$ & $\begin{array}{l}\text { (6) } \\
0.1245 \\
\pm \quad 0.0067\end{array}$ & $\begin{array}{l}\text { (6) } \\
\quad 0.1612 \\
\pm 0.0090\end{array}$ & (3) $\begin{aligned} & \\
& 0.1483 \\
& \pm 0.0193\end{aligned}$ & $\begin{array}{l}\text { (3) } \\
0.1782 \\
\pm 0.0023\end{array}$ & 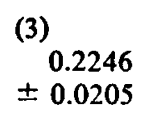 \\
\hline
\end{tabular}

whelming increase in the villous volume occurring at the same time as a consequence of the growth of embryonic connective tissue.

After group IV the degree of branching increases again and up to group VII there is a steep increase in the number of counts per amount of fetal tissue. Around this time almost all the loose connective tissue in the villi has disappeared (fig. 12, A and B), the villi having reached their maximum surface area by means of branching.

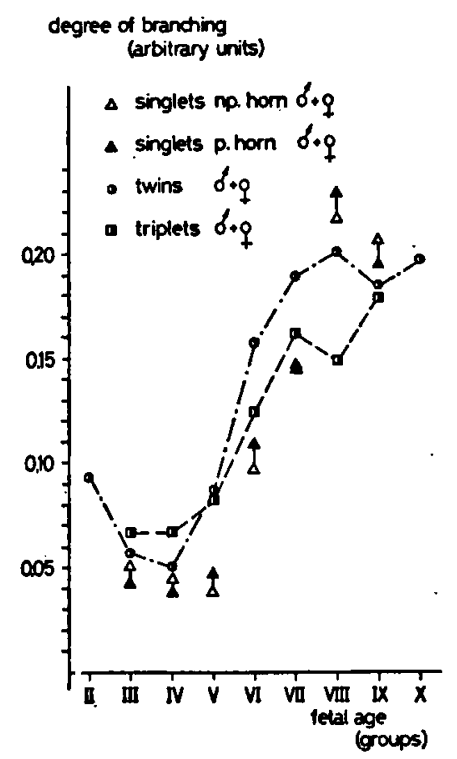

Fig. 13. Degree of branching of the villi. Singlets, twins and triplets compared. Arbitrary units as described in \& 2.3.2.

\section{§ 4.3. The total villous surface of the cotyledonary} mass

The total surface area of the boundary between fetal and maternal tissues inside the placentoma plays a crucial role in the functioning of the placenta. This total surface area will be referred to as the inner surface of the total cotyledonary mass. The product of the degree of branching and the total weight of the cotyledonary mass has been used as a measure of this surface.

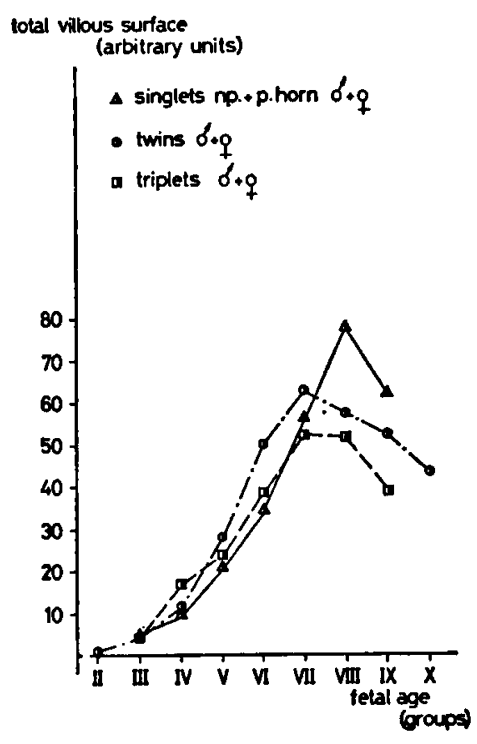

Fig. 14. Total villous surface. Singlets, twins and triplets compared. Arbitrary units as described in $\S 2.3 .2$. 
Table IX. Mean values of the product : branching degree $\times$ cotyledonary weight per placenta $\pm 1 \times$ S.E.M. (expressed in arbitrary units). The numbers of individuals are given in parentheses).

\begin{tabular}{|c|c|c|c|c|c|c|c|c|c|}
\hline Group & II & III & IV & v & VI & VII & VIII & IX & $\mathbf{x}$ \\
\hline $\begin{array}{l}\text { SINGLETS } \\
\text { non-pregnant } \\
\text { horn }\end{array}$ & $\ldots$ & (4) $\begin{aligned} & 1.1725 \\
\pm & 0.2854\end{aligned}$ & $\begin{array}{l}\text { (8) } \\
2.9497 \\
\pm 0.7682\end{array}$ & (4) $\begin{array}{r}5.3390 \\
\pm 1.0171\end{array}$ & $\begin{array}{l}\text { (6) } \\
13.0978 \\
\pm 3.2861\end{array}$ & $\begin{array}{l}(6) \\
\quad 17.4388 \\
\pm 11.7973\end{array}$ & $\begin{array}{l}\text { (12) } \\
23.4858 \\
\pm 2.9245\end{array}$ & $\begin{array}{l}(14) \\
17.8938 \\
\pm 2.2525\end{array}$ & $\begin{array}{l}\text { (1) } \\
14.3592\end{array}$ \\
\hline $\begin{array}{l}\text { SINGLETS } \\
\text { pregnant } \\
\text { horn }\end{array}$ & - & $\begin{array}{l}\text { (5) } \\
\quad 3.2389 \\
\pm 1.1138\end{array}$ & (7) $\begin{array}{r}5.7249 \\
+0.8945\end{array}$ & $\begin{array}{l}\text { (5) } \\
16.1956 \\
\pm 1.7940\end{array}$ & $\begin{array}{l}\text { (6) } \\
23.4539 \\
\pm 1.3997\end{array}$ & $\begin{array}{l}(5) \\
38.7827 \\
\pm 9.5418\end{array}$ & $\begin{array}{l}(14) \\
54.7326 \\
\pm 5.9743\end{array}$ & $\begin{array}{l}(14) \\
43.9534 \\
\pm 5.9420\end{array}$ & - \\
\hline TWINS & $\begin{array}{l}\text { (6) } \\
0.716 \\
\pm 0.120\end{array}$ & $\begin{array}{l}(30) \\
3.9533 \\
\pm 0.4751\end{array}$ & $\begin{array}{l}(25) \\
11.6401 \\
\pm 1.4021\end{array}$ & $\begin{array}{l}(30) \\
28.3097 \\
\pm 2.2337\end{array}$ & $\begin{array}{l}(31) \\
50.0320 \\
\pm 2.8917\end{array}$ & $\begin{array}{l}(32) \\
62.9883 \\
\pm 4.0218\end{array}$ & $\begin{array}{l}(34) \\
56.9621 \\
\pm 3.1817\end{array}$ & $\begin{array}{l}(31) \\
52.9309 \\
\pm \quad 3.1384\end{array}$ & $\begin{array}{l}\text { (14) } \\
43.9367 \\
\pm 5.8721\end{array}$ \\
\hline PLETS & - & (6) $\begin{array}{r}3.8249 \\
\pm 0.4508\end{array}$ & $\begin{array}{l}\text { (6) } \\
16.9272 \\
\pm 0.9841\end{array}$ & $\begin{array}{l}\text { (11) } \\
23.6875 \\
\pm 0.5767\end{array}$ & $\begin{array}{l}\text { (6) } \\
38.2753 \\
\pm 1.5208\end{array}$ & $\begin{array}{l}\text { (6) } \\
52.2087 \\
\pm 0.9653\end{array}$ & $\begin{array}{l}\text { (3) } \\
50.1526 \\
\pm 2.1771\end{array}$ & $\begin{array}{l}\text { (3) } \\
38.7860 \\
\pm 1.5628\end{array}$ & $\begin{array}{l}\text { (3) } \\
57.8061 \\
\pm 11.6214\end{array}$ \\
\hline
\end{tabular}

Table IX summarizes the average values for each group; fig. 14 presents the data as a graph. The results of single and triplet pregnancies will be treated in a separate chapter.

The graph in fig. 14 shows a continuous rise, which indicates a strong and rapid increase of the inner surface area. Although there seems to be a fall in the degree of branching between the groups II and IV, this is not apparent in this figure; the continuous rise is caused by the very steep increase in placental weight in these early phases. After group VII there is a decrease in total inner surface area. The reason is that the placental weight shows a decrease, while the degree of branching does not change; this is illustrated in fig.

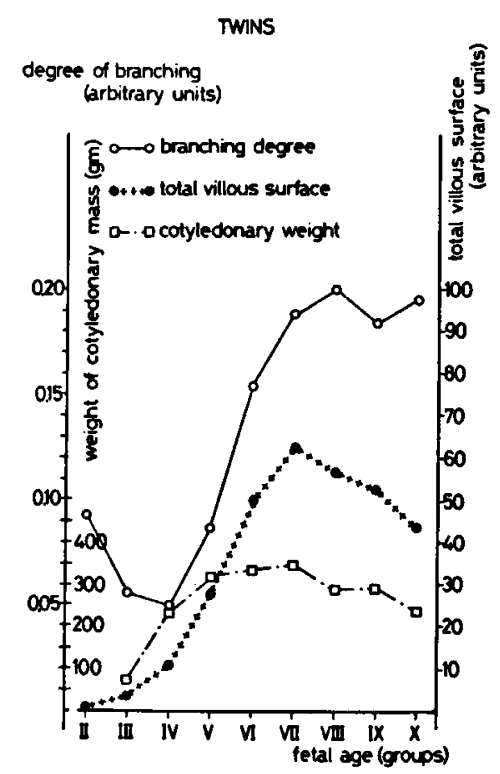

Fig. 15. A composite picture of the development of branching, the total villous surface and the cotyledonary weight in twin placentas.
15 , showing the changes in total villous surface as well as the changes in the degree of branching and in cotyledonary weight.

It is striking that the largest decrease in placental weight takes place after group VII. Between groups V and VII the weight is fairly constant. After group $\mathrm{V}$ the loose connective tissue gradually disappears; in groups VII or VIII it has disappeared completely. Since the cotyledonary weight remains constant from group $\mathrm{V}$ to group VII, it is plausible to suppose that the increase in the degree of branching during this period is real and not just apparent as a consequence of, for instance, a higher density of the villi following the disappearance of the connective tissue component. The increase in the degree of branching between groups VII and VIII, on the other hand. may be explained by the fact that the placental weight shows a considerable decrease during this period.

The decrease of the total inner surface area after group VII is probably caused by the decrease of the cotyledonary mass on one hand, and the very small variations in the degree of branching on the other hand.

\section{\$ 4.4 The vascularization of the cotyledons. Introduction}

Apart from a few central blood vessels in each villus, the greater part of the fetal vascularization consists of a subepithelial plexus, which has been described in full detail by Wimsatt (1950).

It was not possible to study histological material from earlier groups than group II, thus the youngest material studied in the present investigation was from group II. It is remarkable that in 

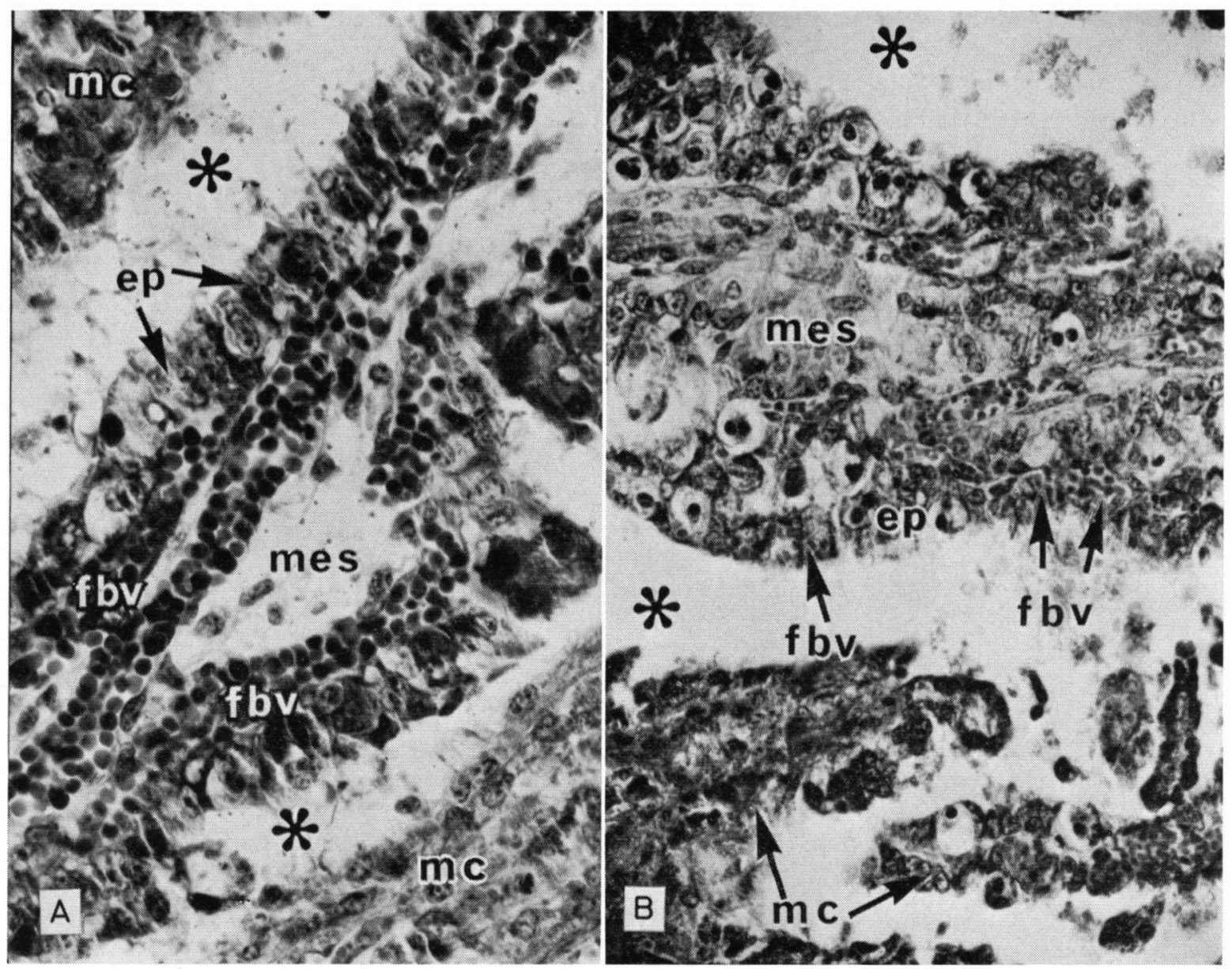

Fig. 16. A. A villus in a very young cotyledon (early group II) (X 520). Note the abundant vascularization. B. A villus (group VII) with ingrowth of capillaries between the epithelial cells (arrows) $(X 520)$. ep $=$ chorionic epithelial cells; $*=$ artificial space. For further abbreviations, see $\$ 2.3 .3$.

the younger stages (group II) the villi contained many blood vessels (fig. 16, A). When the villi become larger only the profile of a subepithelial vessel is seen. In group $\mathrm{V}$ it is apparent that the vascular diameter shows some increase. Around stage VI it seems that the number of profiles in each villus increase. In groups VII to $X$ not only an increase in the number and diameter of the blood vessels can be seen, but it is also apparent that the blood vessels become situated in between the cells of the epithelium. There is the impression that a capillary wall often directly borders onto the free surface. It should be noted, however, that it has become clear from electron microscopic studies (Davies \& Wimsatt, 1966) that the blood vessels always remain covered by fetal components such as the basement membrane of the chorionic epithelium. This ingrowth of capillar- ies can be observed as early as group VI. Both Davies \& Wimsatt (1966) and Barcroft \& Barron (1946) have observed this phenomenon around day 100. The material used by these authors was precisely dated, so that it is not possible to relate exactly their findings to the data obtained from the present material, which is classified in groups of estimated age. The phenomenon as such is unmistakable in the present material and there is rough chronological agreement. Macroscopically, the cotyledons have a pale pink color in the younger age groups. As a consequence of the increase in the number of blood vessels they become darker, and in the older age groups they are coloured a deep red.

The intra-epithelial occurrence of blood vessels is explained by Barcroft \& Barron by the assumption that the vessels are forced into the epithelium 
because of the lack of space following the disappearance of the embryonic connective tissue. They assume that the collapsing villi fold themselves around the blood vessels during this process. In the present study it appears that, since there is no such lack of space, the phenomenon must be determined chronologically. It appeared that, even in villi in which sufficient room is still present because not all of the mesenchymal tissue has disappeared, the capillaries move in between the epithelial cells; this is illustrated in fig. 16, B which shows a villus from a placenta in group VII. One gets the impression that an active ingrowth mechanism takes place, more or less coinciding with the moment at which the increase in surface area by means of branching has come to an end.

\section{$\S 4.5$ Quantification of the vascularization of the villi}

In table $\mathrm{X}$ the indices on the average degree of vascularization are summarized. The methods and arbitrary units used are described in chapter 2. This section is restricted to the treatment of twin pregnancies, chapter 6 will deal with singlets and triplets.

In group II there is a relatively high number of blood vessels discernible in each villus; the degree of vascularization is high. When in later stages the villi are growing and only a few blood vessels are seen in each villus, this results in a relative decrease in the degree of vascularization (fig. 17). After group IV the degree of vascularization increases again, an increase partly caused by the disappearance of the thin connective

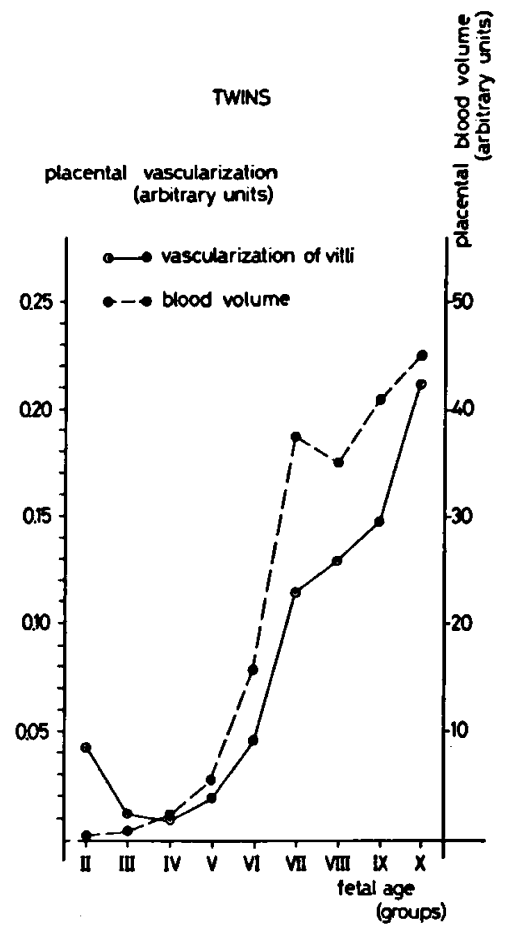

Fig. 17. Placental vascularization and blood volume compared.

tissue which brings the blood vessels closer to. gether. A definite increase is apparent after group VI. Between groups VII and IX the slope of the curve becomes less steep. This shallower increase coincides with the dip in the curve of the degree of vascularization of the caruncles (fig. 10). Here also one could suppose that in these groups both the maternal and fetal blood vessels are partly collapsed for some unclear reason.

After group IX the curve again resumes its steep increase.

Table X. Mean values of the degree of vascularization per placenta $\pm 1 \times$ S.E.M. (expressed in arbitrary units). (The numbers of individuals are given in parentheses).

\begin{tabular}{|c|c|c|c|c|c|c|c|c|c|}
\hline Group & II & III & IV & V & VI & VII & VIII & IX & $\mathbf{x}$ \\
\hline $\begin{array}{l}\text { SINGLETS } \\
\text { non-pregnant } \\
\text { horn }\end{array}$ & $\begin{array}{l}\text { (2) } \\
0.0094 \\
\pm 0.0026\end{array}$ & $\begin{array}{l}\text { (4) } \\
0.0282 \\
\pm 0.0087\end{array}$ & $\begin{array}{l}\text { (8) } \\
0.0256 \\
\pm 0.0041\end{array}$ & $\begin{array}{l}\text { (4) } \\
0.0237 \\
\pm 0.0049\end{array}$ & (6) $\begin{array}{r}0.0477 \\
\pm 0.0068\end{array}$ & $\begin{array}{l}\text { (6) } \\
0.0706 \\
\pm 0.0137\end{array}$ & $\begin{array}{l}\text { (13) } \\
0.1296 \\
\pm 0.0105\end{array}$ & $\begin{array}{r}\text { (14) } \\
0.1606 \\
+0.0131\end{array}$ & - \\
\hline $\begin{array}{l}\text { SINGLETS } \\
\text { pregnant } \\
\text { horn }\end{array}$ & (3) $\begin{array}{r}0.0205 \\
\pm 0.0115\end{array}$ & $\begin{array}{l}\text { (5) } \\
0.0191 \\
\pm 0.0042\end{array}$ & (7) $\begin{array}{r}0.0275 \\
\pm 0.0086\end{array}$ & $\begin{array}{l}\text { (6) } \\
\quad 0.0235 \\
\pm 0.0070\end{array}$ & 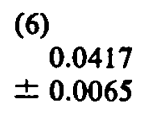 & $\begin{array}{l}\text { (6) } \\
0.0907 \\
\pm 0.0200\end{array}$ & $\begin{array}{l}\text { (18) } \\
0.1418 \\
\pm 0.0126\end{array}$ & $\begin{array}{l}\text { (18) } \\
0.1790 \\
\pm 0.0167\end{array}$ & - \\
\hline WINS & $\begin{array}{l}\text { (18) } \\
0.0425 \\
\pm 0.0052\end{array}$ & $\begin{array}{l}(30) \\
0.0117 \\
\pm 0.0016\end{array}$ & $\begin{array}{l}\text { (26) } \\
\quad 0.0096 \\
\pm 0.0015\end{array}$ & $\begin{array}{l}(30) \\
0.0191 \\
\pm 0.0041\end{array}$ & $\begin{array}{l}(30) \\
0.0460 \\
\pm 0.0054\end{array}$ & $\begin{array}{l}(30) \\
0.1149 \\
\pm 0.0102\end{array}$ & $\begin{array}{l}\text { (31) } \\
\quad 0.1290 \\
\pm 0.0099\end{array}$ & $\begin{array}{l}(30) \\
0.1475 \\
\pm 0.0143\end{array}$ & $\begin{array}{l}\text { (14) } \\
0.2123 \\
\pm 0.0187\end{array}$ \\
\hline RIPLETS & - & $\begin{array}{l}\text { (9) } \\
0.0210 \\
\pm 0.0018\end{array}$ & (6) $\begin{aligned} & \\
& 0.0191 \\
& \pm 0.0036\end{aligned}$ & $\begin{array}{l}\text { (11) } \\
0.0194 \\
\pm 0.0027\end{array}$ & 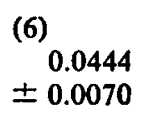 & $\begin{array}{l}\text { (6) } \\
0.0441 \\
\pm 0.0049\end{array}$ & (3) $\begin{array}{r}0.0878 \\
+0.0044\end{array}$ & $\begin{array}{l}\text { (3) } \\
0.1243 \\
\pm 0.0383\end{array}$ & (3) $\begin{array}{r}0.1654 \\
\pm 0.0128\end{array}$ \\
\hline
\end{tabular}


Table XI. Mean values of the total placental blood volume (product of : vascularization $\times$ cotyledonary weight per placenta), expressed in arbitrary units. (The numbers of individuals are given in parentheses).

\begin{tabular}{|c|c|c|c|c|c|c|c|c|c|}
\hline Broup & II & III & IV & V & VI & VII & VIII & IX & $\mathbf{x}$ \\
\hline $\begin{array}{l}\text { SINGLETS } \\
\text { non-pregnant } \\
\text { horn }\end{array}$ & - & (4) $\begin{aligned} & \\
& 0.5617 \\
& \pm 0.1942\end{aligned}$ & $\begin{array}{l}\text { (8) } \\
2.4936 \\
\pm 0.5010\end{array}$ & (4) $\begin{array}{r}3.2249 \\
\pm 1.2364\end{array}$ & (6) $\begin{aligned} & \\
& 5.7541 \\
& \pm 1.2554\end{aligned}$ & $\begin{array}{l}\text { (6) } \\
7.7488 \\
\pm 3.1190\end{array}$ & $\begin{array}{l}\text { (12) } \\
12.9179 \\
\pm 1.6074\end{array}$ & $\begin{array}{l}(14) \\
14.2164 \\
\pm 2.1397\end{array}$ & - \\
\hline $\begin{array}{l}\text { SINGLETS } \\
\text { pregnant } \\
\text { horn }\end{array}$ & - & (5) $\begin{array}{r}1.2213 \\
\pm 0.4840\end{array}$ & $\begin{array}{l}\text { (7) } \\
2.5182 \\
\pm 0.9115\end{array}$ & (6) $\begin{array}{r}8.1125 \\
\pm 3.1777\end{array}$ & $\begin{array}{l}\text { (6) } \\
8.2304 \\
\pm 1.2571\end{array}$ & $\begin{array}{l}\text { (6) } \\
22.9213 \\
\pm 2.8433\end{array}$ & $\begin{array}{l}(18) \\
34.0947 \\
\pm 4.8046\end{array}$ & $\begin{array}{l}\text { (18) } \\
30.4365 \\
\pm 2.9395\end{array}$ & - \\
\hline WINS & $\begin{array}{l}\text { (6) } \\
0.2120 \\
\pm 0.0529\end{array}$ & $\begin{array}{l}\text { (30) } \\
0.8581 \\
\pm 0.1401\end{array}$ & $\begin{array}{r}(26) \\
2.1028 \\
\pm 0.4347\end{array}$ & $\begin{array}{r}\text { (30) } \\
5.5943 \\
\pm 0.0487\end{array}$ & $\begin{array}{l}(30) \\
15.8625 \\
\pm 2.2250\end{array}$ & $\begin{array}{l}(30) \\
37.6264 \\
\pm 2.8354\end{array}$ & $\begin{array}{l}\text { (34) } \\
35.1794 \\
\pm 2.8197\end{array}$ & $\begin{array}{l}\text { (30) } \\
41.7837 \\
\pm 4.5667\end{array}$ & $\begin{array}{l}\text { (14) } \\
45.0991 \\
\pm 4.1501\end{array}$ \\
\hline RIPLETS & - & (6) $\begin{array}{r} \\
1.2903 \\
\pm 0.2962\end{array}$ & $\begin{array}{l}\text { (6) } \\
4.6353 \\
\pm 0.4018\end{array}$ & $\begin{array}{l}\text { (11) } \\
5.7578 \\
\pm 0.7704\end{array}$ & $\begin{array}{l}\text { (6) } \\
13.1919 \\
\pm 1.7202\end{array}$ & $\begin{array}{l}\text { (6) } \\
14.5835 \\
\pm 1.7756\end{array}$ & $\begin{array}{l}\text { (3) } \\
30.7254 \\
\pm 4.4830\end{array}$ & $\begin{array}{l}\text { (3) } \\
28.1870 \\
\pm 6.3597\end{array}$ & $\begin{array}{l}\text { (3) } \\
41.5534 \\
\pm 4.0902\end{array}$ \\
\hline
\end{tabular}

$\S 4.6$ The blood volume of the total cotyledonary mass

The average blood volume per placenta is calculated as the product of the degree of vascularization and the total cotyledonary weight.

Table XI gives the data on the average blood volume per placenta in the different stages of pregnancy. This parameter too is only discussed with reference to twin pregnancies. From fig. 17 it is clear that this blood volume shows a continuous increase, except between groups VII and VIII where the curve shows a definite decrease, which probably has to be ascribed to two factors: the loss of the weight of the cotyledons and the shallower increase in the degree of vascularization, mentioned in $\S 4.5$. After this dip the curve resumes its former course. Summarizing, it can be said that despite a decrease in placental weight, both the degree of vascularization and the blood volume keep increasing.

\section{$\S 4.7$ Relationships between the various parameters}

Fig. 18 gives an overall survey of the changes of cotyledonary weight, degree of branching, total villous surface, degree of vascularization and blood volume. It appears that when the cotyledons have reached their maximum size the enlargement of the villous surface still continues by the mechanism of the splitting up of villi into fine branches. At the time when the placenta attains its largest inner surface area, it appears that the efficiency of the organ can increase still further because of a continuing development of the vascular system. The combination of the factors mentioned here makes it possible for the placenta

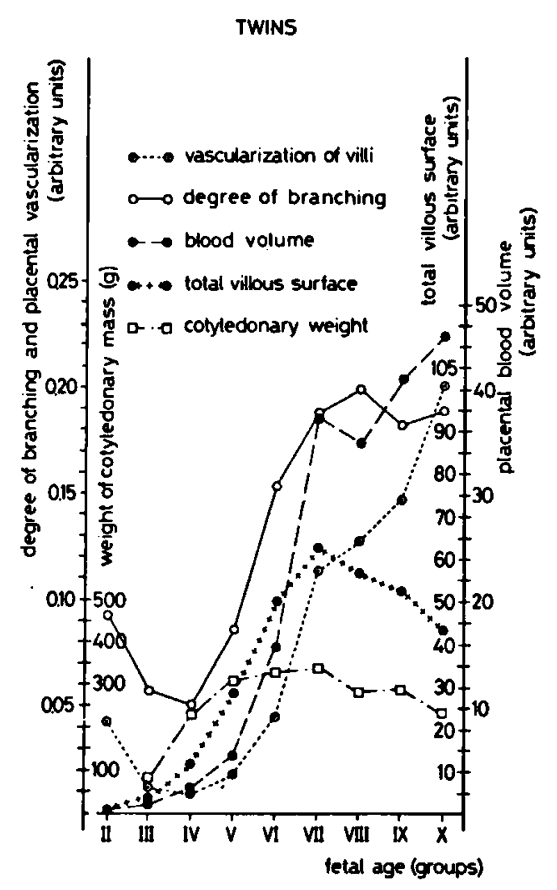

Fig. 18. A composite picture, summarizing the chronological changes taking place in twin placentas.

to increase its blood volume right to the end of pregnancy, and by this process it can meet the demands of the growing fetus.

Section 1. The relationship between the weight of uterine horns and the vascularization of caruncles (fig. 19, table XII).

Applying Kendall's rank correlation test (Wijvekate, 1963) no significant correlation is found between the weight of the uterus and the vascularization of the caruncles. Only in group VII there is a significant positive correlation. Though there 
Table XII. The correlation between the various parameters, applying Kendall's rank correlation test.

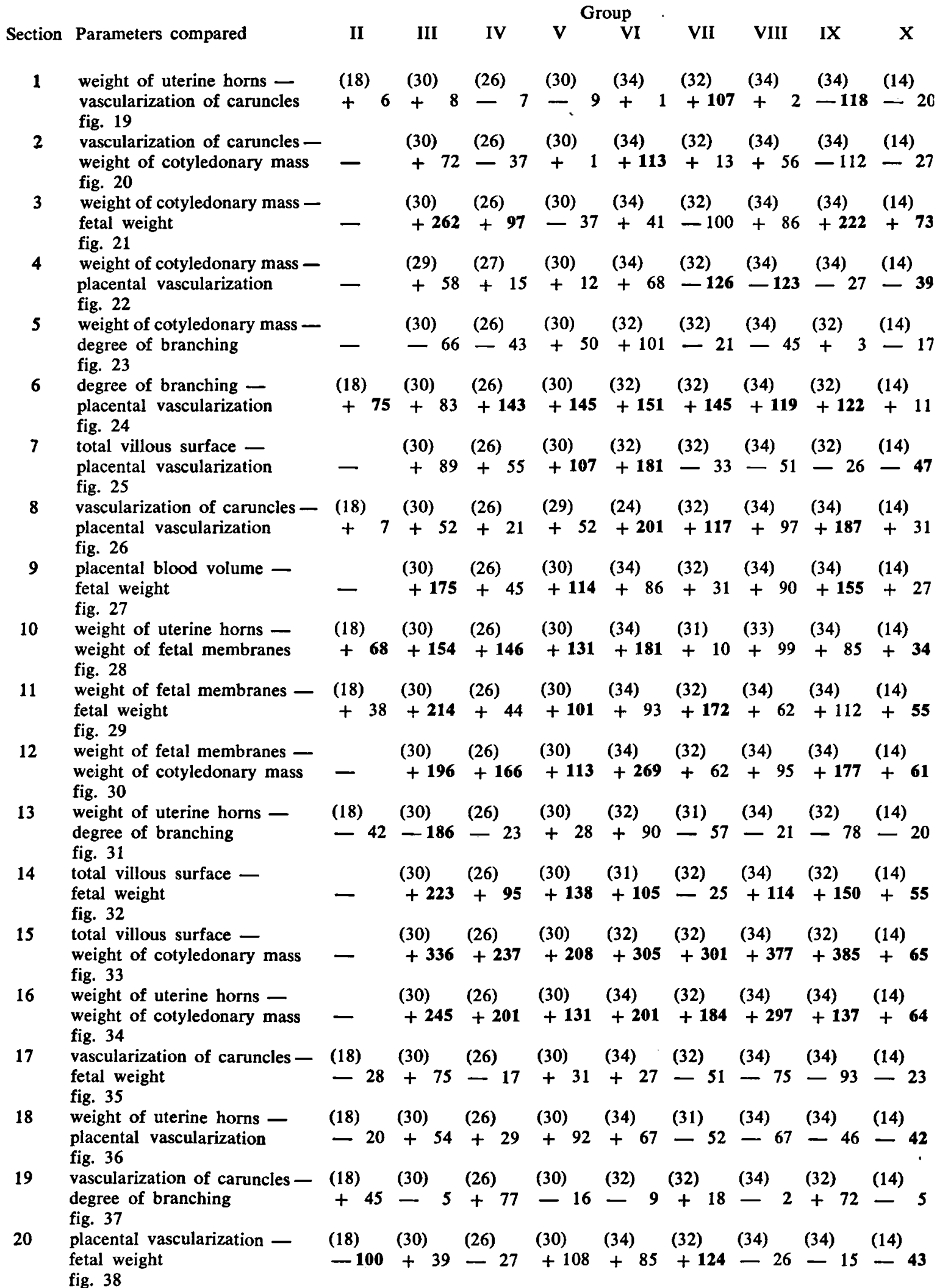


21

vascularization of caruncles -

fig. 39

22

23

vascularization of caruncles placental blood volume fig. 40 degree of branching fetal weight fig. 41

The numbers of individuals are given in parentheses.

Bold type indicates a significant correlation at a 0.05 level at least.

(18) (30) (26)

$-3+91-46$

(30) (34)

(32)

(34)

(34)

(14)

(30) (26) (30) (34) (32) (34) (34)

(14)

$+87-11+82+196+130+120+49-11$

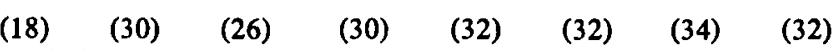

(14)

$-104-73-59+182+117+73-14-58-11$

Critical values of $S$ in the Kendall rank correlation test at the 0.05 level of significance :

$\begin{array}{llllllllll}\mathrm{N} & 14 & 18 & 26 & 27 & 29 & 30 & 32 & 33 & 34 \\ \mathrm{~S} & 33 & 45 & 77 & 81 & 90 & 95 & 104 & 108 & 113\end{array}$

are macroscopic differences in vascularization between nulligravid and multiparous non-pregnant uteri as a whole, it is apparent that those differences are not found in the caruncles. The reason for this could be the fatty degeneration of the caruncles taking place after each pregnancy, resulting in a total obliteration of the vessels in the greatest part of the caruncle, of which only minimal elevations are left. It cannot be stated if and to what extent the correlation found in group VII has to be ascribed to differences in parity of the mothers, since, in this material, no relevant data are available.

Though in group IX there is a significant negative correlation, it is not clear what significance has to be attached to this correlation, more so since vascularization of the caruncles in group IX shows a decrease ( $\S 4.5)$, a phenomenon which cannot be explained either.

Section 2. The relationship between the vascularization of caruncles and the weight of cotyledonary mass (fig. 20, table XII).

In group III there is a positive correlation. This correlation, however, appears not to be statistically significant. A significant positive correlation is found in group VI; this could be expected on account of the increase of cotyledonary weight in this group ( $\S 3.2 .3$ ). In the younger groups both the cotyledonary weight and the num. ber of blood vessels in the caruncles are increasing (§ 3.3.2). The maximum cotyledonary weight for twins is reached in group VI (fig. 8). Since the cotyledonary mass does not increase after group VI, it would be expected that the highest correlation - if any - between uterine vascularization and cotyledonary weight would be found in this group, which indeed appears to be the case. After group VI the cotyledons loose some weight, the positive correlation disappears and it even seems that in groups IX and $X$ there is a negative, though not significant, correlation.

Uterine vascularization still increases until group VII, but this can be of no importance for the cotyledonary weight, which attains its maximum in group $\mathrm{V}$ or VI.

Section 3. The relationship between the weight of the cotyledonary mass and fetal weight (fig. 21, table XII).

A highly significant correlation between the weight of the cotyledons and fetal weight is present in group III; this correlation is still present in group IV, though less significant. After group IV the correlation disappears, but returns in group VIII, though not significant. In groups IX and $X$ there is a significant positive correlation again. It should be pointed out, however, that there is probably an essential difference between the two correlations. It seems possible that the correlation in groups III and IV reflects age differences within the groups. In these groups the small fetuses with small placentas are younger than the larger fetuses with their larger placentas present in the same age group. This is true for group III and, to a lesser extent, also for group IV. The correlation in this group becomes less because of the growth-spurt of the placenta. In the younger groups the placenta grows mainly exponentially. The fetus grows at a lower rate than the placenta. The greatest weight increase of the fetus takes place in the higher age groups. After group VI the placenta no longer gains weight. The correlation between cotyledonary weight and fetal weight seen in the higher age groups is caused by the placenta being a limiting factor for 


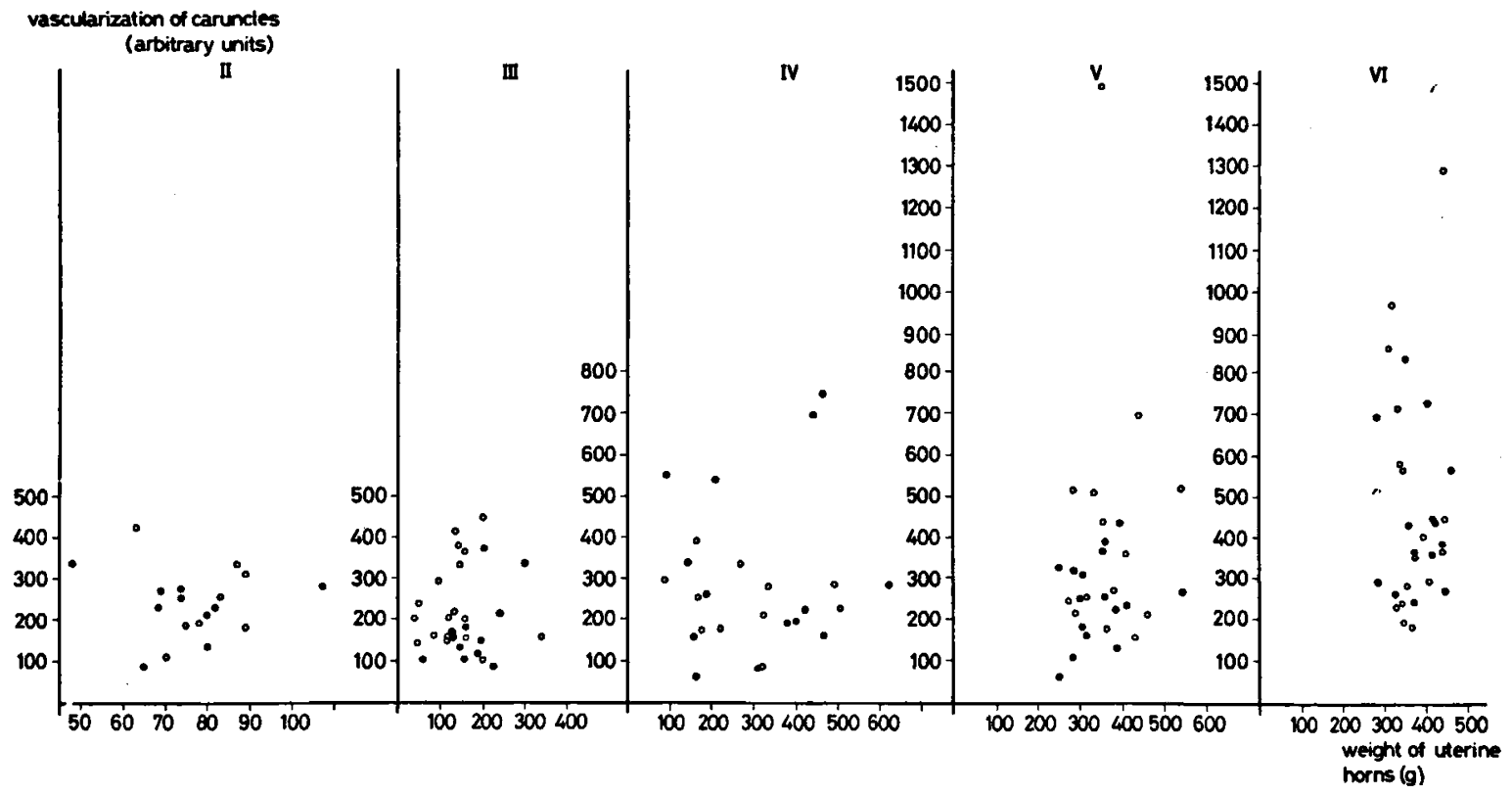

weight of uterine horns (g)

Fig. 19. The relationship between the weight of uterine $h$ orns and the vascularization of caruncles. 
vascularization of caruncles
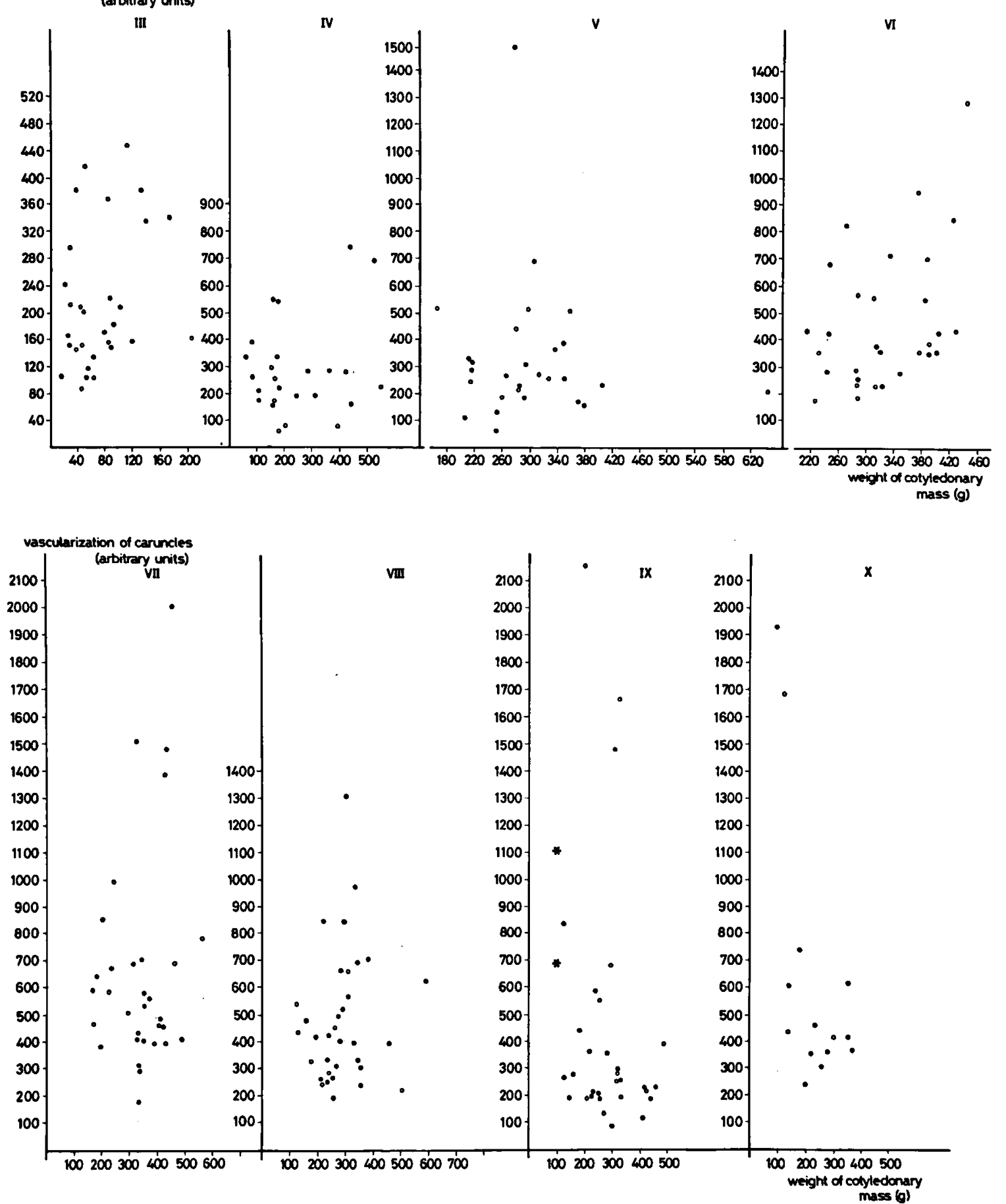

Fig. 20. The relationship between the vascularization of caruncles and the weight of cotyledonary mass. 

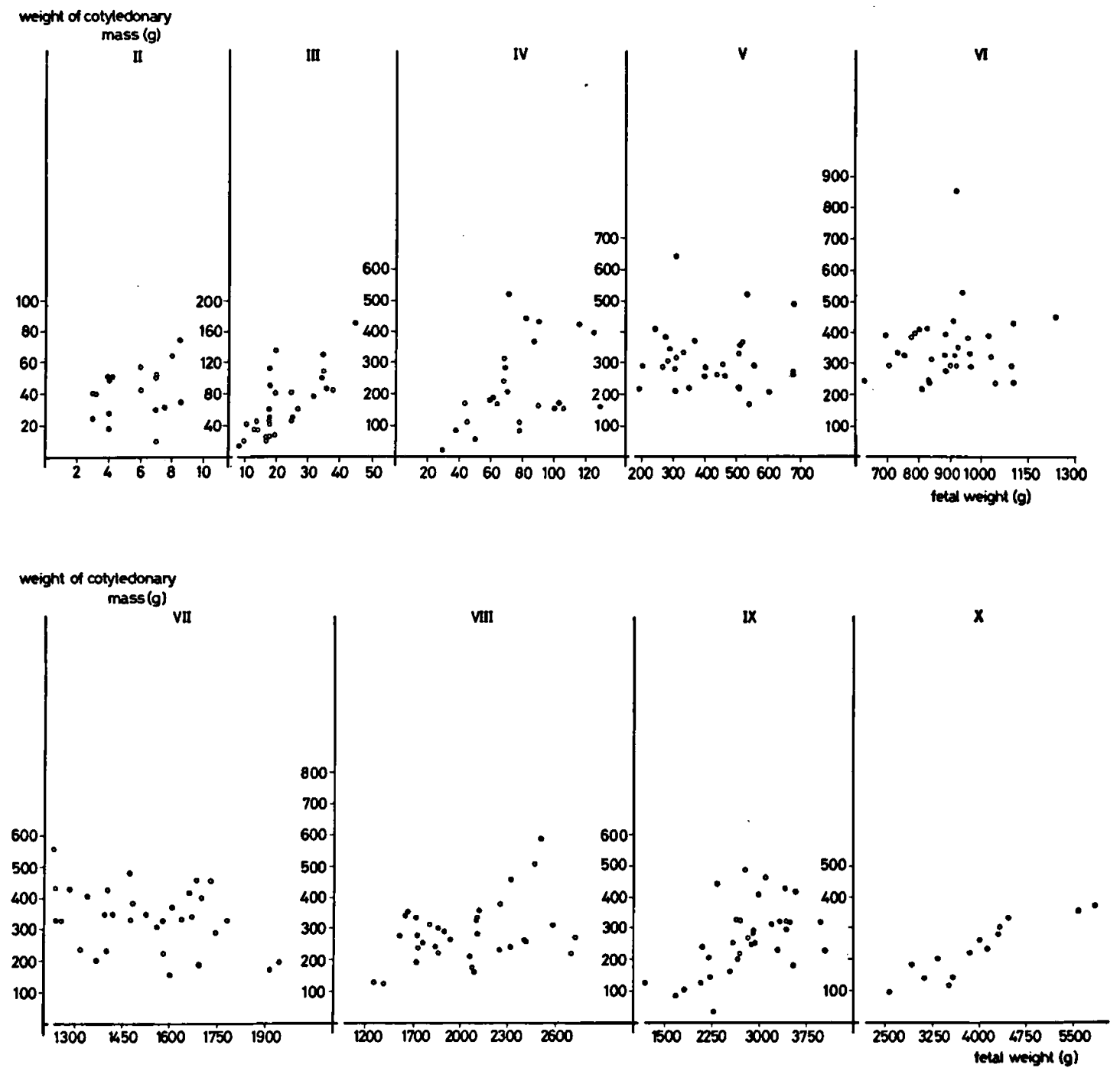

Fig. 21. The relationship between the weight of the cotyledonary mass and fetal weight.

fetal growth. If in younger age groups a larger placenta has formed, the fetus can go on growing longer before the placenta has reached its maximum capacity. A correlation between birth weight and placental weight is also mentioned in the literature (Naaktgeboren \& Stegeman, 1969).

Section 4. The relationship between the weight of the cotyledonary mass and placental vascularization (fig. 22, table XII).

In groups III to VI there is no significant correlation between the weight of the cotyledonary mass and the placental vascularization. A remarkable finding (table XII) is the sudden appearance of a significant negative correlation in group VII. This may be explained on the basis of observations made on the vascularization ( $\$ 4.5$ ) and branching patterns (\$ 4.2). The placental weight does not increase after group V or VI, whereas the degree of branching in groups VII or VIII to $\mathrm{X}$ remains constant. The degree of vascularization on the other hand keeps increasing until the end of pregnancy. The negative correlation existing between the cotyledonary mass and the degree of vascularization, which is clear from group VII onward, strongly suggests a compensatory mechanism localized in the capillary plexus of the villi. The lower the cotyledonary weight, the more strongly do the blood vessels have to expand in the case of a postulated compensation mechanism in order to supply the fetus with sufficient means for its development. It should be pointed out that this 

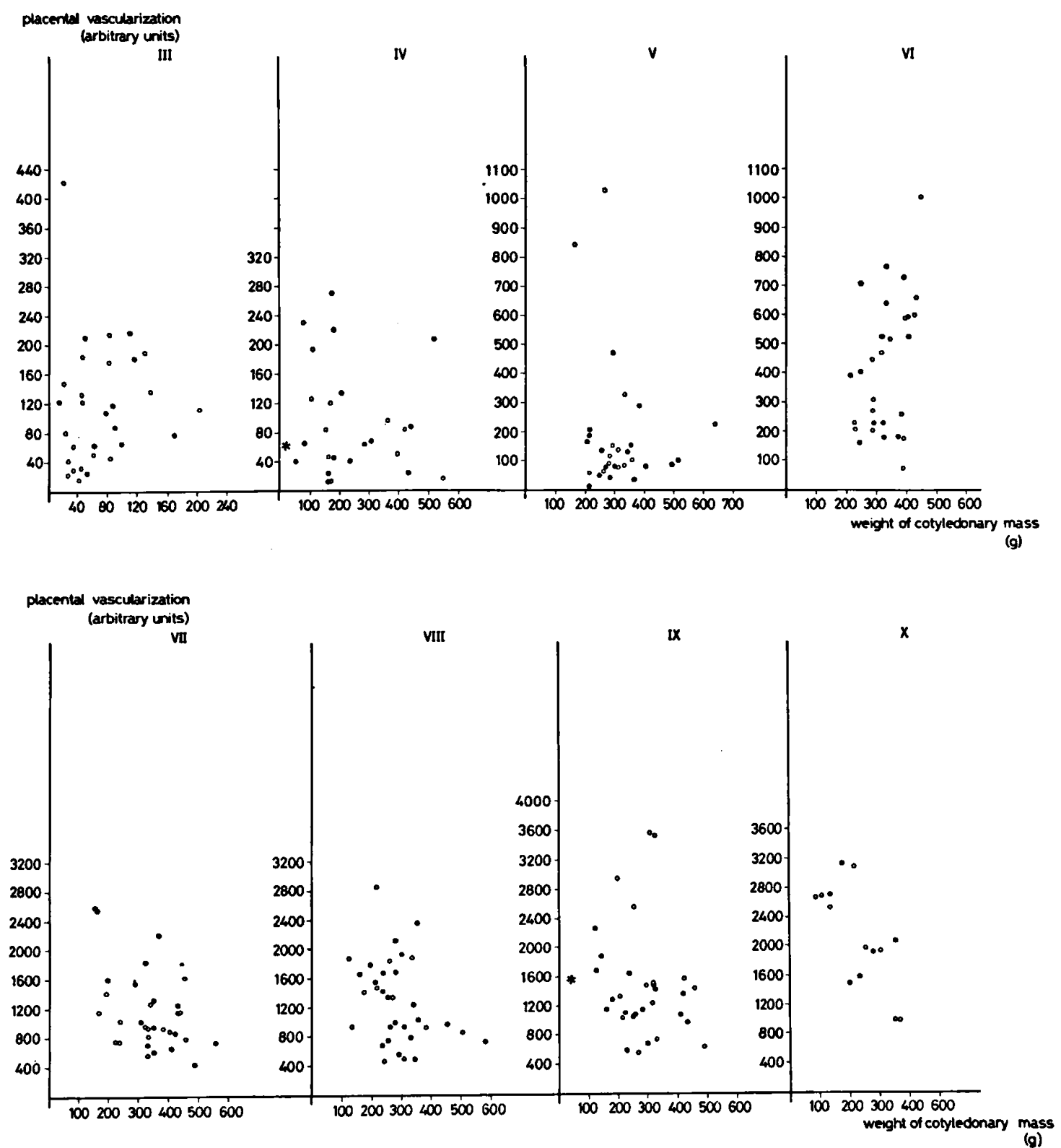

Fig. 22. The relationship between the weight of the cotyledonary mass and placental vascularization.

mechanism does not result in a total compensation. This follows from the large variation in birth weight: $3-7 \mathrm{~kg}$ in the Texel breed (Naaktgeboren \& Stegeman, 1969). The positive correlation in higher age groups between cotyledonary weight and fetal weight as described in section 3 also leads to the conclusion that a placenta which is too small remains deficient despite the outgrowth of fetal blood vessels.

Section 5. The relationship between the weight of the cotyledonary mass and the degree of branching (fig. 23, table XII).
In groups III and IV there seems to be a negative correlation between the weight of the cotyledonary mass and the degree of branching which, however, is not statistically significant. This negative correlation could be explained along the same lines as in section 3 by age differences between placentas within each group. In the somewhat older placentas the villi have enlarged because of the developing stroma. These older placentas are heavier as a consequence of villous en. largement, but have a relatively lower degree of branching than the somewhat younger placentas in which this thin hydrophilic tissue has not yet 

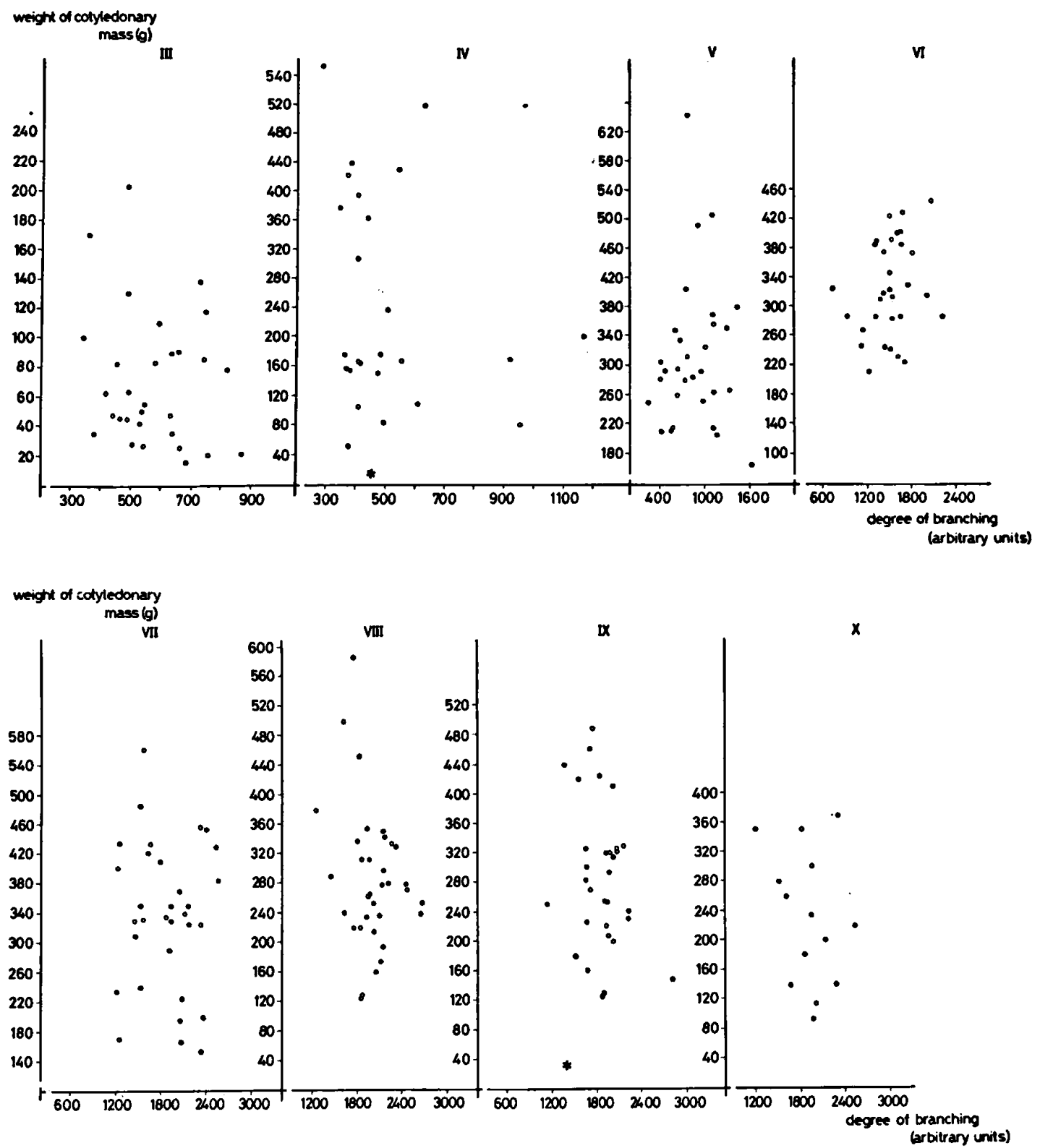

Fig. 23. The relationship between the weight of the cotyl edonary mass and the degree of branching.

developed to such an extent. Such a younger placenta is lighter and, because of its smaller villi, gives the impression of having a higher degree of branching.

In stages V to VIII the degree of branching increases because of the development of third-order branches in this period. After group IV no significant correlations between the weight of the cotyledonary mass and the degree of branching are found. This lack of correlation between cotyledonary mass and degree of branching is in accordance with the view expounded in section 15 that branching follows an invariable pattern, independent of other parameters such as cotyledonary mass.

Section 6. The relationship between the degrea of branching and placental vascularization (fig. 24, table XII).

With the exception of groups III and $X$ there is a significant positive correlation between the degree of branching and the placental vascular- 

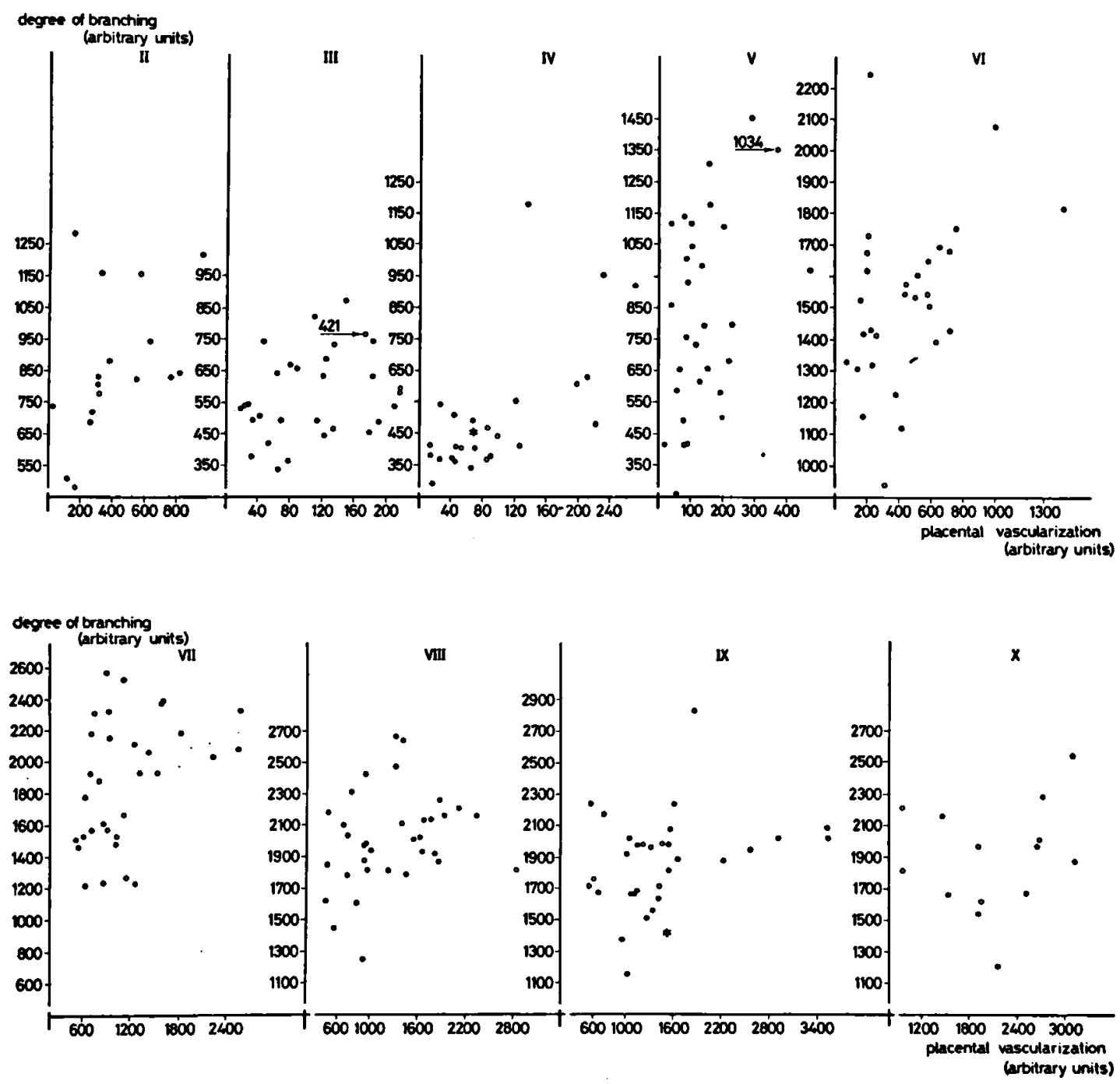

Fig. 24. The relationship between the degree of branching and placental vascularization.

ization in all groups. In group II it can be seen that the villi, which are still quite small, have a dense capillary plexus. Both the degree of branching and the degree of vascularization are relatively high. In groups III and IV the villi enlarge and, as a consequence, the degree of branching seems to decrease, as does the density of the blood vessels. In group VI to VII or VIII, both the degree of branching and the degree of vascularization increase. Their branching activity comes to an end while the vascularization keeps increasing. In group IX the correlation is still present, but in group $X$ it has almost disappeared because the outgrowth of blood vessels has continued while the branching activity has come to a standstill.
Section 7. The relationship between total villous surface and placental vascularization (fig. 25 , table XII).

Up to group VI inclusive there is a definite positive correlation between the total villous surface and placental vascularization, which probably develop at an equal pace up to that time. In groups V and VI this correlation is significant. After group VII the cotyledonary weight no longer increases but even shows a decrease. However, the degree of vascularization keeps on increasing. It has been mentioned in section 4 that after group VII there is a negative correlation between placental weight and the degree of vascularization. Since the measure used as a parameter for the inner villous surface was obtained by the 

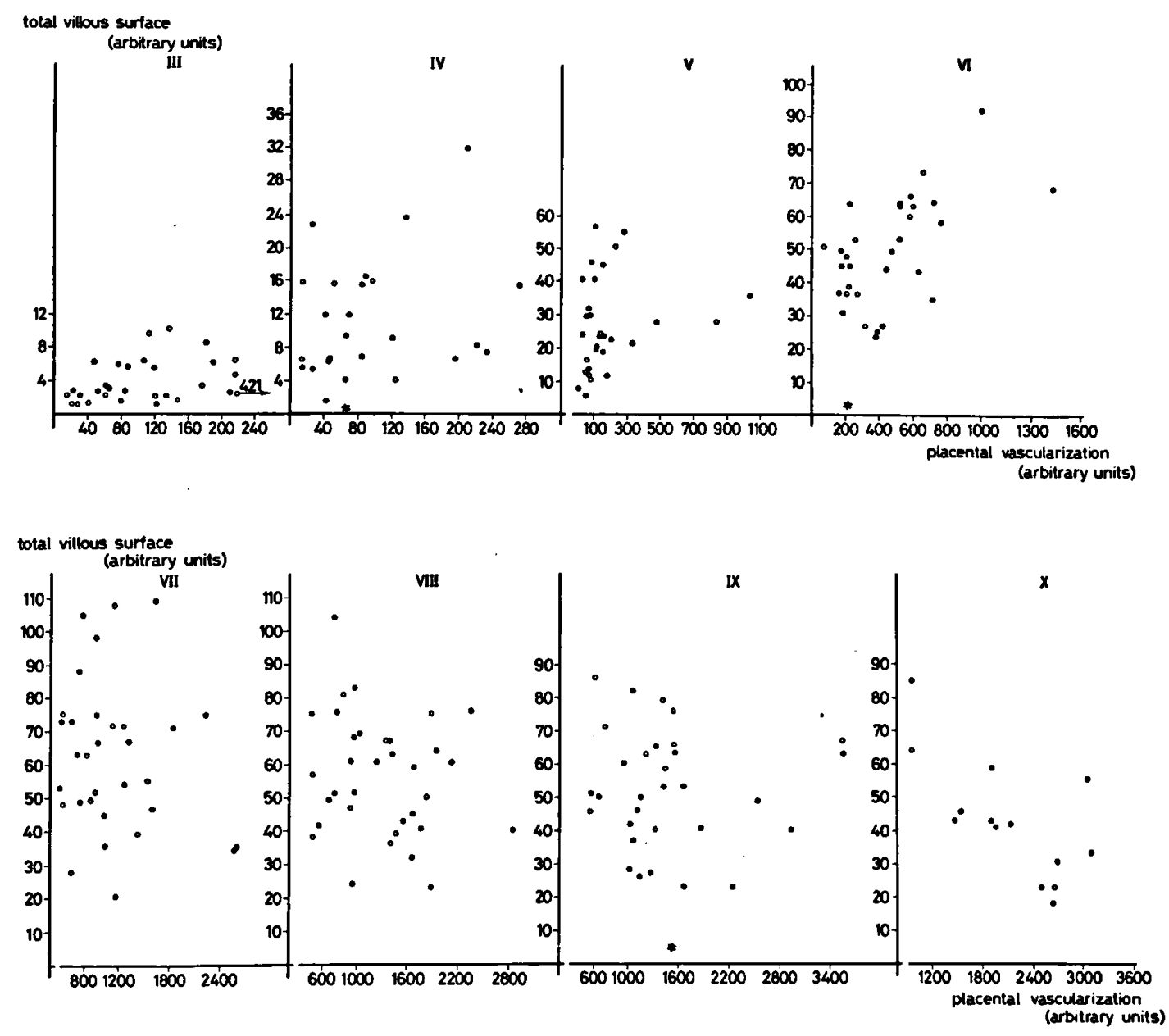

Fig. 25. The relationship between total villous surface and placental vascularization.

multiplication: cotyledonary weight $\times$ degree of branching, this surface area is almost entirely determined by the placental weight (see section 15) since the degree of branching in this period remains fairly constant. The negative correlation which occurs from group VII onwards between total villous surface and the degree of vascularization therefore was to be expected on the basis of the considerations given in section 4 .

Section 8 . The relationship between the vascularization of the caruncles and placental vascularization (fig. 26, table XII).

In the higher age groups (VI, VII and IX) a significant positive correlation is seen. Since the vascularization of the uterus no longer increases after group VII this could point to an adaptation of the placenta to its supply, i.e., the vasculariza- tion of the caruncles. In other words, a continuing proliferation of blood vessels in the placenta will only take place for as long as such a proliferation makes sense in the face of the maternal blood supply.

Anticipating the general discussion in chapter 7 it is of interest to observe that, under physiological conditions, the placenta in its reaction seems to depend on the maternal supply. In the human only a direct reaction to a suboptimal functioning of the maternal supply can be observed in the form of placental infarcts (Kubli, 1964; Werner, 1972; Wallenburg, 1969). In sheep this relationship implies not only that an insufficient caruncular vascularization hampers villous vascularization, but also that the reverse may occur; optimum caruncular vascularization seems to be a stimulus for placental villous vascularization. 

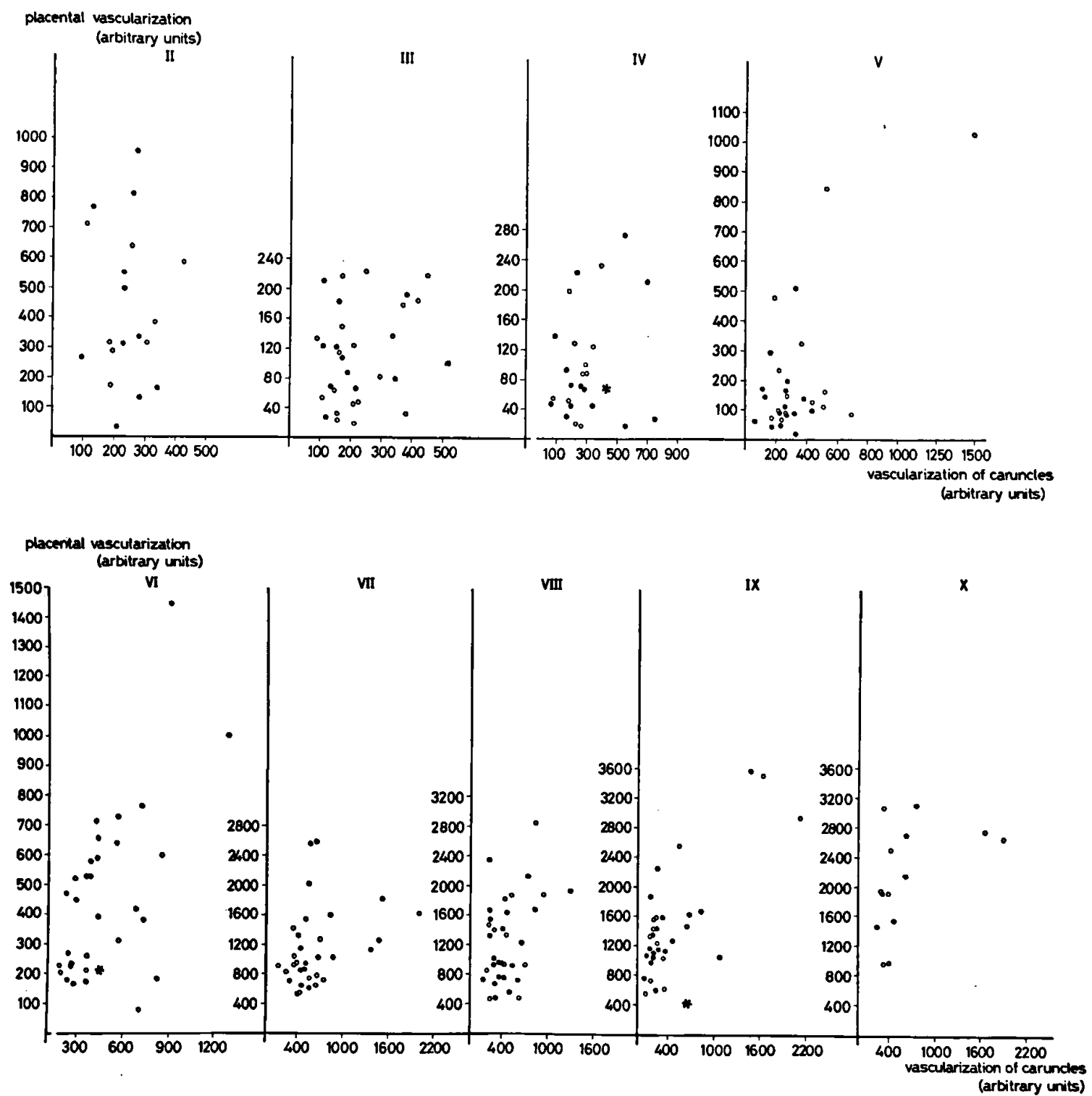

Fig. 26. The relationship between the vascularization of the caruncles and placental vascularization.

Section 9. The relationship between placental blood volume and fetal weight (fig. 27, table XII).

The very high positive correlation found in group III possibly has to be ascribed to age differences within this group. After group III the correlation becomes less marked. This development is not unexpected if it is considered that in the lower age groups in normal cases the demands of the developing fetus can be met easily. In the higher age groups the total blood volume increasingly plays a decisive role, and in group IX there is again a definite positive correlation. A slight cor- relation is already visible in group VIII; it is also present in group $\mathrm{X}$, though not statistically significant.

It should be recalled that in this study placental blood volume is defined as: weight of cotyledonary mass $X$ degree of vascularization. In section 3 a positive correlation was found between the weight of cotyledonary mass and fetal weight, which is highly significant in groups IX and X. Further, a significant negative correlation was found between the weight of the cotyledonary mass and the degree of vascularization from group VII onwards. A high degree of correlation be- 

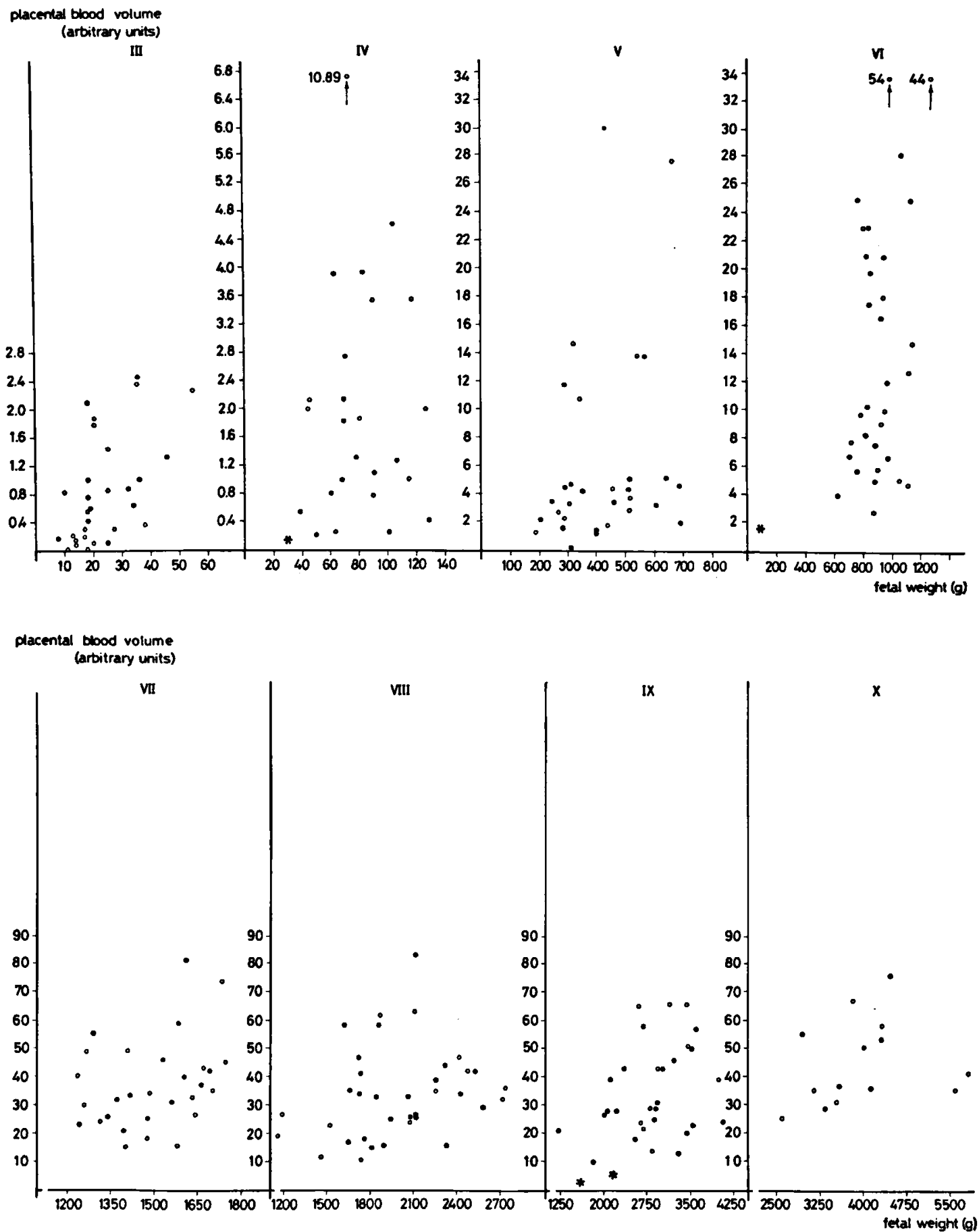

Fig. 27. The relationship between placental blood volume and fetal weight.

tween the placental blood volume and the fetal weight might therefore be expected. From table XII the conclusion can be drawn that the highest correlation is present between the weight of the cotyledonary mass (i.e., total villous surface, see section 15) and fetal weight. The compensatory mechanism of vascularization makes its appearance as early as group VII in those cases where placental weight (i.e., capacity expressed as total in. ner surface) is too small to meet the fetal demands (compare also section 7). From the lower correlation between placental blood volume and 

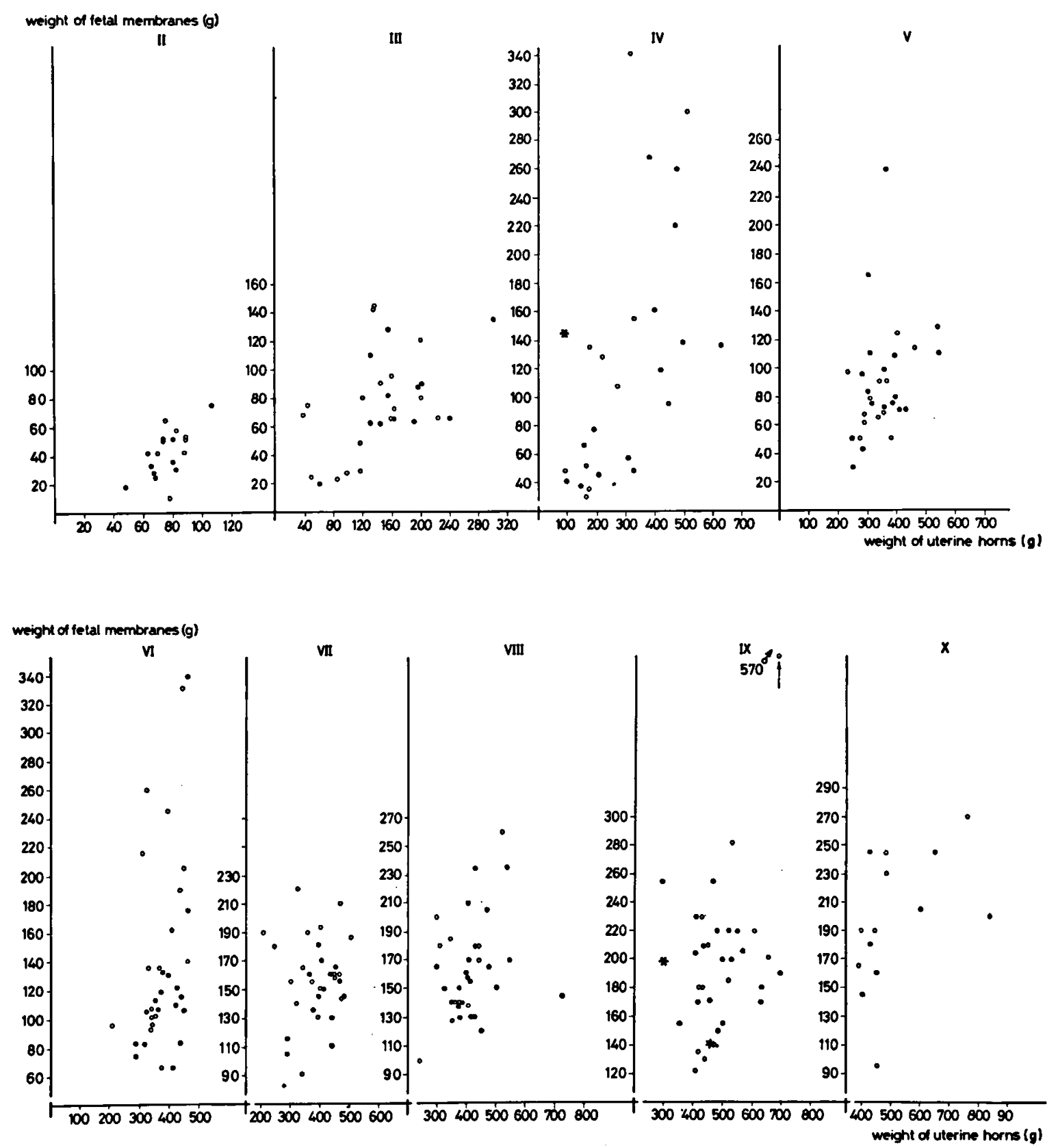

Fig. 28. The relationship between the weight of uterine horns and weight of fetal membranes.

fetal weight the tentative conclusion could be drawn that it is not the absolute blood volume, but rather the effectiveness of this volume ("inner surface") which is the most decisive factor.

Section 10. The relationship between the weight of uterine horns and the weight of fetal membranes (fig. 28, table XII).

In nearly all age groups there is a definite positive correlation, which is especially marked up to group VI. In these early stages the greater part of the membranes consist of the chorionic and allantoic membranes, whereas in the second half of pregnancy it is especially the amniotic membrane which shows a continuous increase (Wallace, 1948). It may be put that the significant correlation in the groups II to VI refers mainly to the growth of the chorionic and allantoic membranes. After group VI a correlation is almost absent, whereas in group $\mathrm{X}$ there is again a significant correlation 

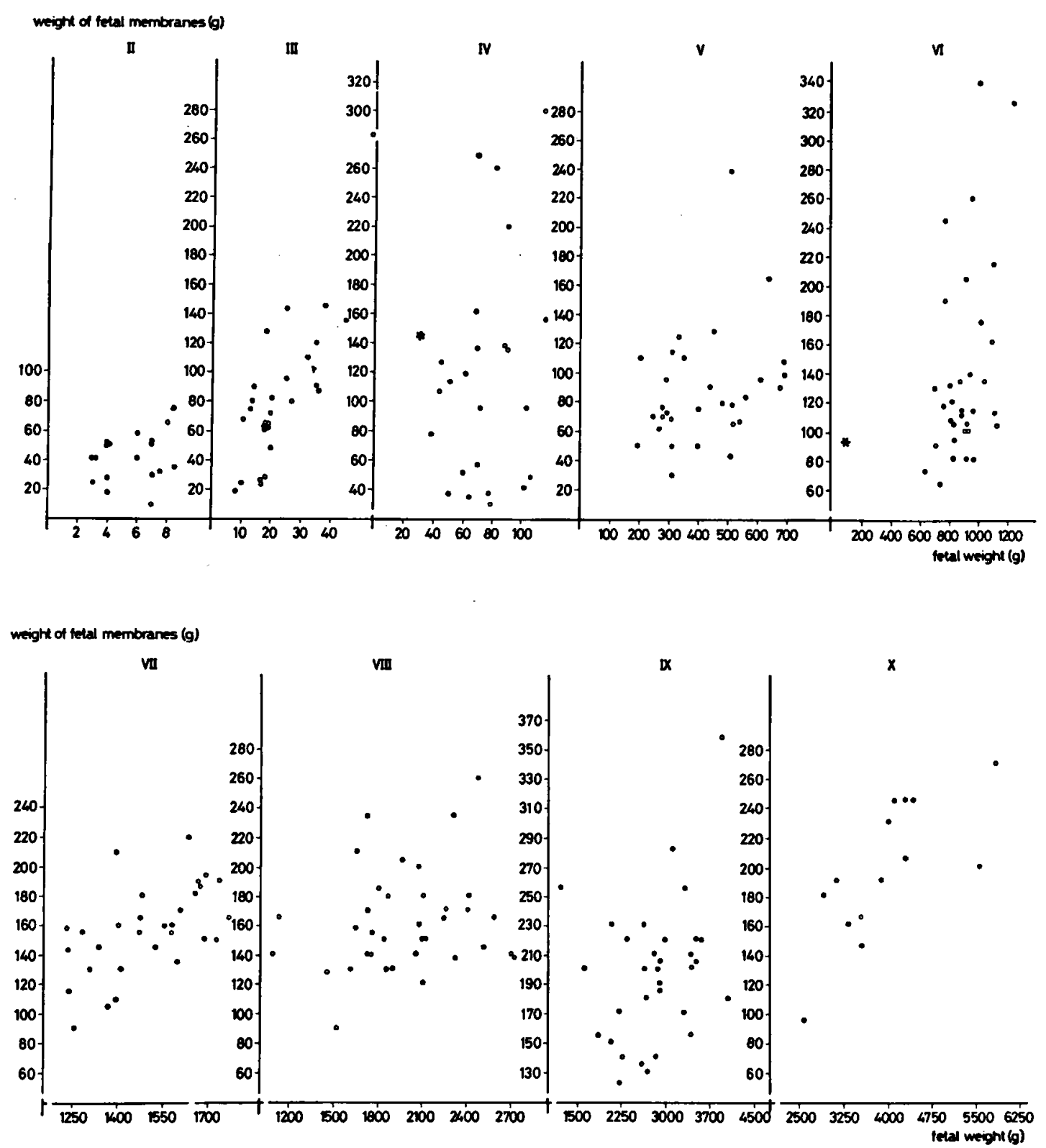

Fig. 29. The relationship between the weight of fetal membranes and fetal weight.

between the weight of the uterus and the weight of the total fetal membranes. The cause of this relationship is not clear. Possibly this latter correlation is an indirect one, since a large uterus as a rule contains a large fetus. If it is assumed that such a large fetus is accompanied by a large amnion, but that the amnion does not increase in weight very fast, the correlation seen in group $X$ only would have found an explanation.
Section 11. The relationship between the weight of fetal membranes and fetal weight (fig. 29, table XII).

Perhaps the significant positive correlation in group III here also has to be ascribed to age differences within the group. The membranes, in particular, grow very fast in the beginning. the fetal weight showing a relatively high degree of dispersion. The correlation later decreases. 

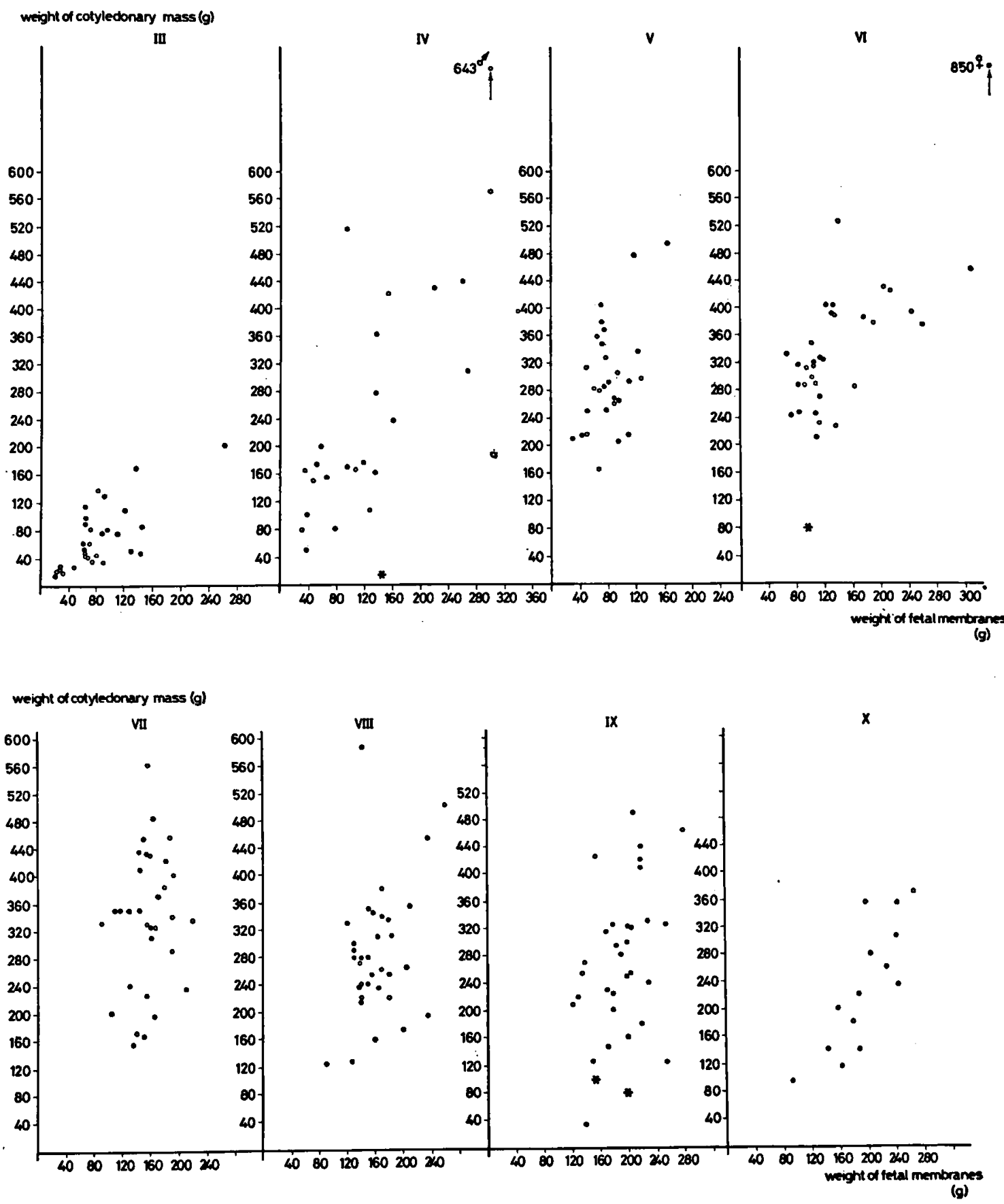

Fig. 30. The relationship between the weight of fetal membranes and the weight of cotyledonary mass.

From group VII upward there is again a significant positive correlation between the weight of the total membranes and the fetal weight. Here the investigations of Wrobel \& Kühnel $(1966,1968)$ should be mentioned. These authors presented data which make it plausible to suppose that the fetal membranes play an important role in establishing fetal weight.
Section 12. The relationship between the weight of fetal membranes and the weight of cotyledonary mass (fig. 30 , table XII).

In all groups there is a definite positive correlation between the weight of fetal membranes and the weight of cotyledonary mass, which is significant in all groups with the exception of groups VII and VIII. A similar finding was presented 

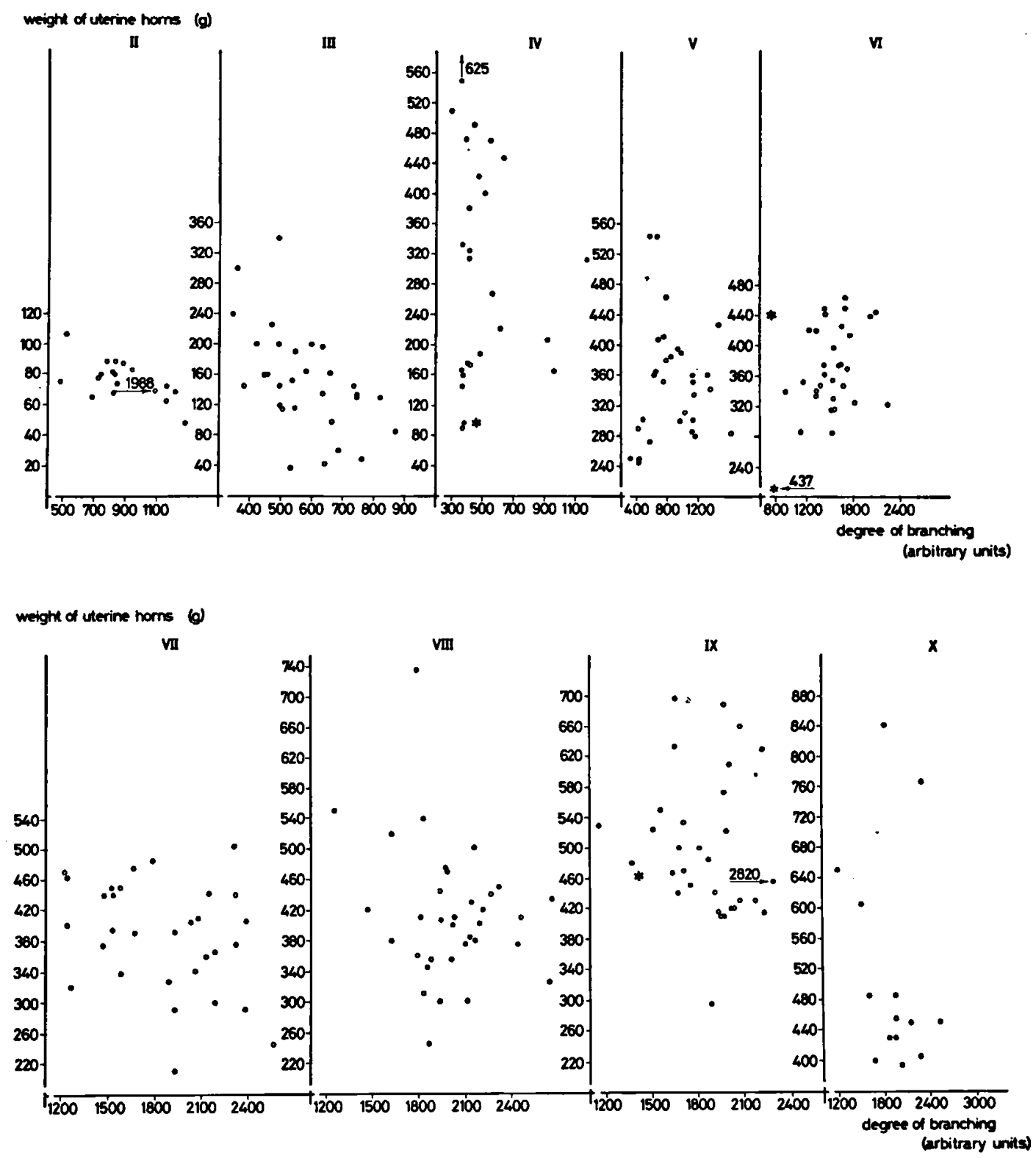

Fig. 31. The relationship between the weight of the uterine horns and the degree of branching.

by Naaktgeboren \& Stegeman (1969). These authors showed that the weight of the total cotyledonary mass was proportional to the weight of the membranes. Thus, not only does a positive correlation between the weight of the cotyledons and the fetal weight exist from group VII or VIII onwards, but also between the weights of the whole afterbirth and of the newborn.

Section 13. The relationship between the weight of the uterine horns and the degree of branching (fig. 31, table XII).
In groups II and III there is a negative correlation between the weight of the uterine horns and the degree of branching; in group III this correlation is significant. This would mean that in the younger age groups the placenta makes fewer or larger villi in a heavy uterus than in a small uterus. One should keep in mind that the uterus of a non-pregnant pluriparous animal is not only twice as heavy as the uterus of the nulligravid animal, but also its volume is larger. If group III is divided into a number of subgroups according to placental weight, this tendency 
appears more clearly: a placenta of the same age group and with a given weight shows a higher degree of branching in a small uterus than in a bigger one.

As an illustration the group of uteri with cotyledonary weights between 20 and $29 \mathrm{~g}$ has been selected (table XIII).

Table XIII. Correlation between uterine weight and the degree of villous branching in group III.

$\begin{array}{ccc}\begin{array}{c}\text { Weight of } \\ \text { cotyledonary } \\ \text { mass }(\mathrm{g})\end{array} & \begin{array}{c}\text { Weight of } \\ \text { uterine horns } \\ \text { (g) }\end{array} & \begin{array}{c}\text { Degree of } \\ \text { branching } \\ \text { (arbitrary units) }\end{array} \\ 20 & 60 & 0.0762 \\ 21 & 85 & 0.0872 \\ 25 & 98 & 0.0667 \\ 27 & 117 & 0.0546 \\ 28 & 117 & 0.0502\end{array}$

This difference is only obvious in groups II and III, and disappears in the following stages when the villi show more actual branching. It should again be recalled that in the youngest stages (II and III) a high degree of branching is only apparent, meaning that there are more but smaller villi per field of view than in a placenta of the same age where the degree of branching seems low. It could be speculated that in the case of a large uterus the initial stem villi are formed as larger and plumper structures. Where the villi all have a similar pattern of differentiation the volume of the initially formed villi could perhaps be a decisive factor in determining cotyledonary weight.

Section 14. The relationship between total villous surface and fetal weight (fig. 32, table XII).

In groups III to VI a definite positive correlation is seen between the total villous surface and the fetal weight. This probably does not point to a bilateral interdependance, but rather is a consequence of an equally determined develop-
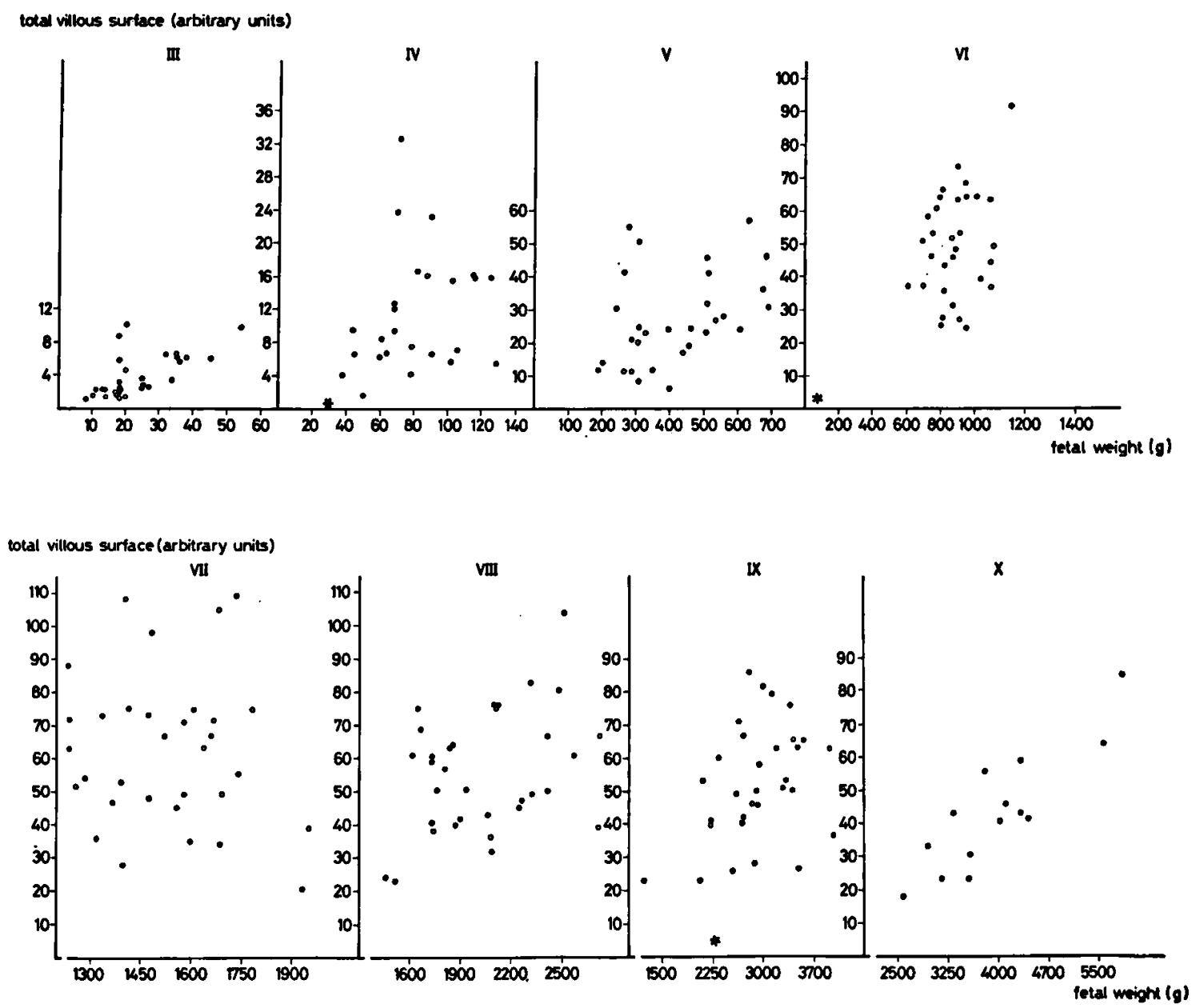

Fig. 32. The relationship between total villous surface and fetal weight. 

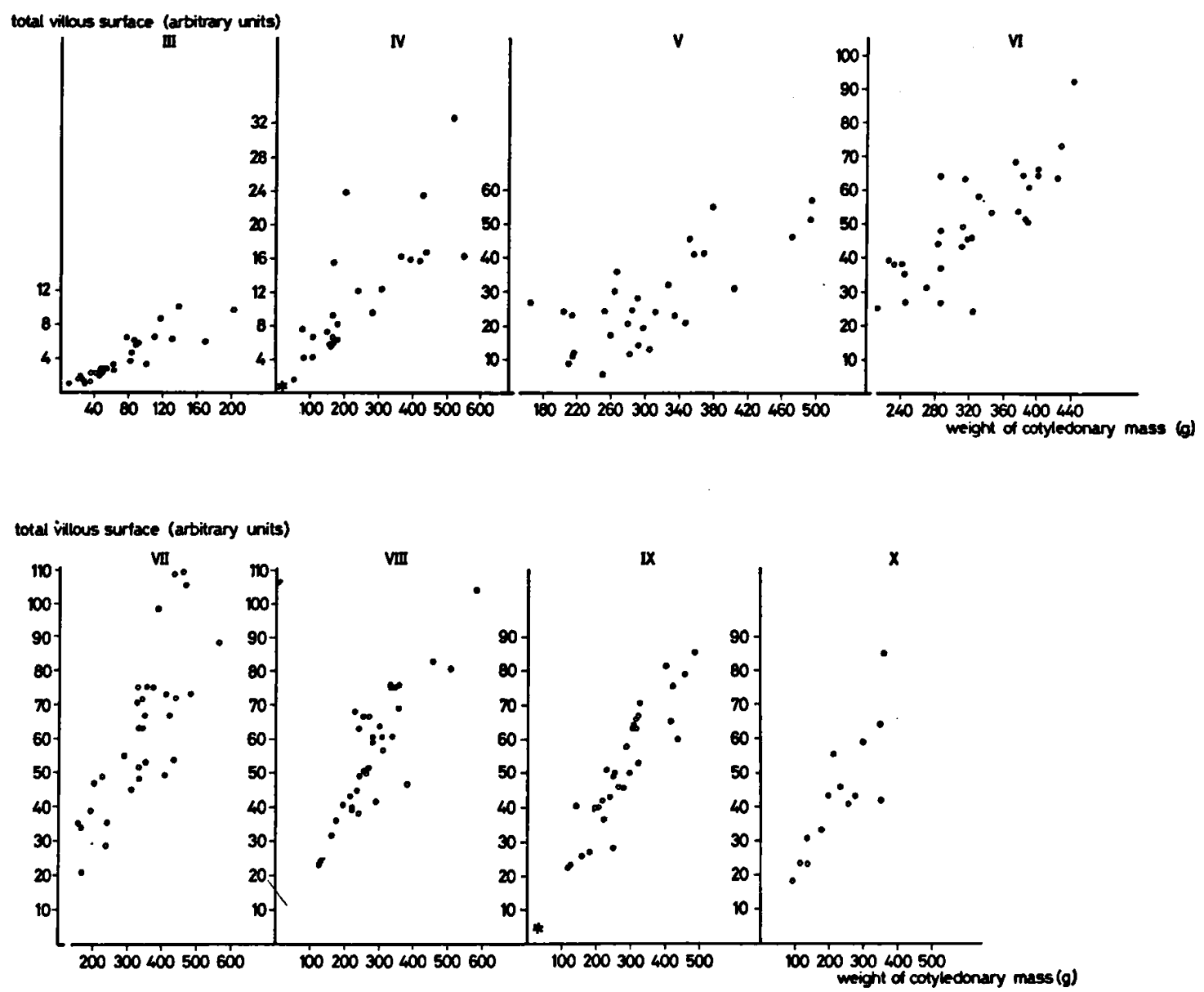

Fig. 33. The relationship beween total villous surface and the weight of the cotyledonary mass.

mental pattern. In group VII the correlation is no longer found, whereas in groups VIII, IX and $\mathrm{X}$ there is again a significant positive correlation. In these latter stages the total villous surface has become a limiting factor, since this parameter no longer shows a rise after group VIII, but even shows a decrease. It should be recalled that at this stage (group VIII) a negative correlation between total villous surface and vascularization appears (see also section 7).

Section 15. The relationship between total villous surface and the weight of the cotyledonary mass (fig. 33, table XII).

In all groups (III to $\mathrm{X}$ ) a significant positive correlation appears to be present between the cotyledonary weight and the total villous surface. This correlation remains even when the weight increase of the cotyledons has come to a standstill and the degree of branching no longer shows an increase. The implication is that the degree of branching reaches a fixed value, in other words that in the case of a small placenta there is no compensation by means of exaggerated branching; on this point there is a difference with the degree of vascularization, which may be considered to be a compensatory mechanism. It is important to note that the total inner surface does not keep increasing until the end of pregnancy, but clearly comes to a standstill (group VIII) or even shows a decline ( $\S 4.3$ ).

Section 16. The relationship between the weight of the uterine horns and the weight of the cotyledonary mass (fig. 34, table XII).

In all groups there is a highly significant positive correlation between the weight of the uterine horns and the weight of the cotyledonary mass. This agrees with the results of the earlier investigation of Naaktgeboren \& Stegeman (1969) who also found a constant positive correlation between the uterine weight and the weight of the 

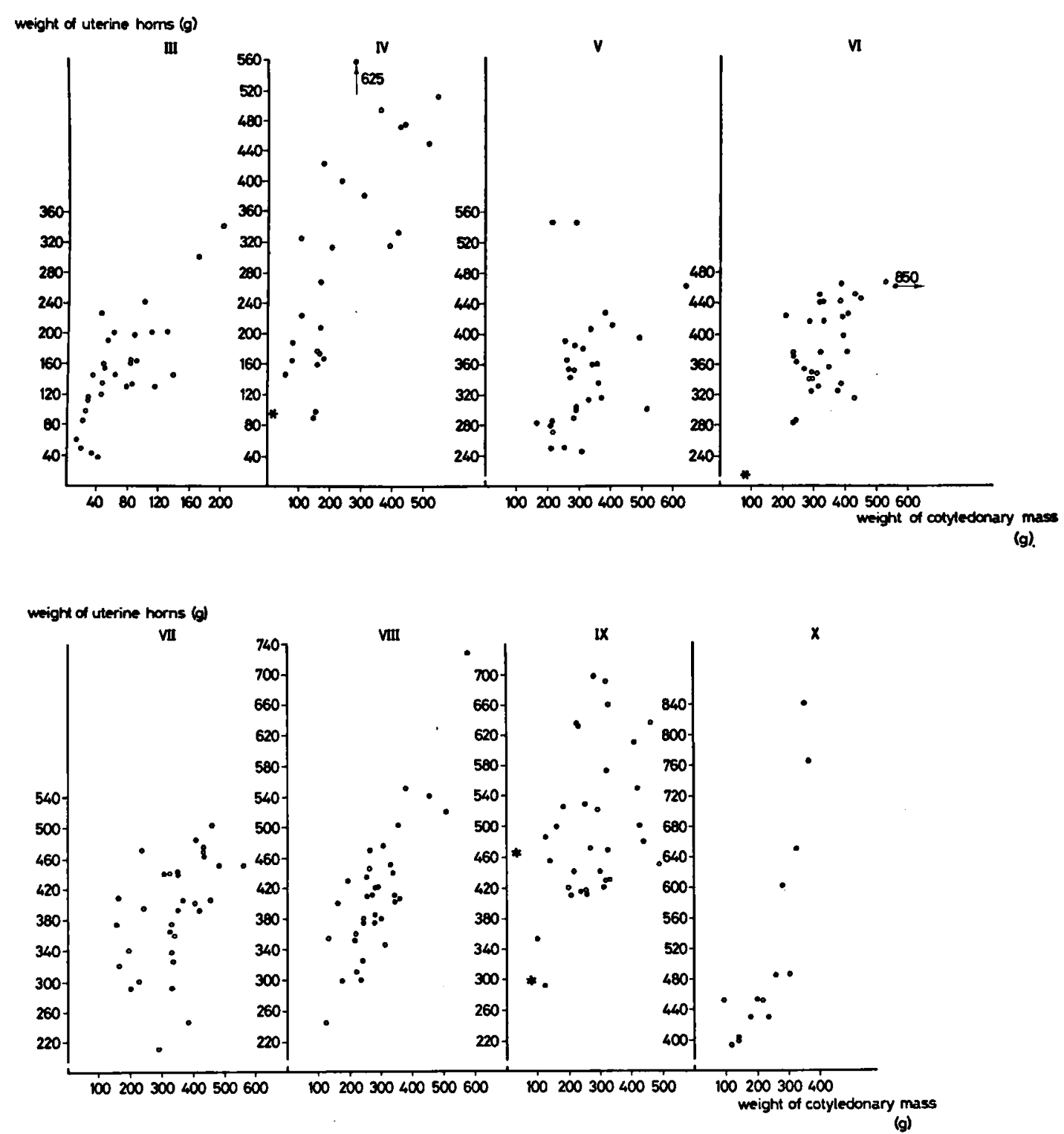

Fig. 34. The relationship between the weight of the uterine horns and the weight of the cotyledonary mass.

whole afterbirth. Since a positive correlation also exists between the weight of the cotyledonary mass and the weight of the fetal membranes, correlation between the weight of the uterine horns and the weight of the cotyledonary mass was to be expected.

Here the possibility has to be faced that a large conceptus could stimulate the uterus to grow bigger and faster. This hypothesis has to be rejected however, because in the case of twins and triplets the total uterine weight at the end of pregnancy does not differ significantly from that of singlets (table VI, fig. 9).

The correlation is already apparent in the very young stages in which the membranous part of the placenta constitutes the principal component, whereas the cotyledons are only beginning to form.

Section 17. The relationship between the vascularization of the caruncles and fetal weight (fig. 35 , table XII).

In none of the groups was a significant correlation seen between the vascularization of the caruncles and fetal weight. This correlation was to be expected neither in the younger nor in the older age groups. As regards the younger groups, external factors which could possibly hamper the development of the fetus are not effective earlier than 

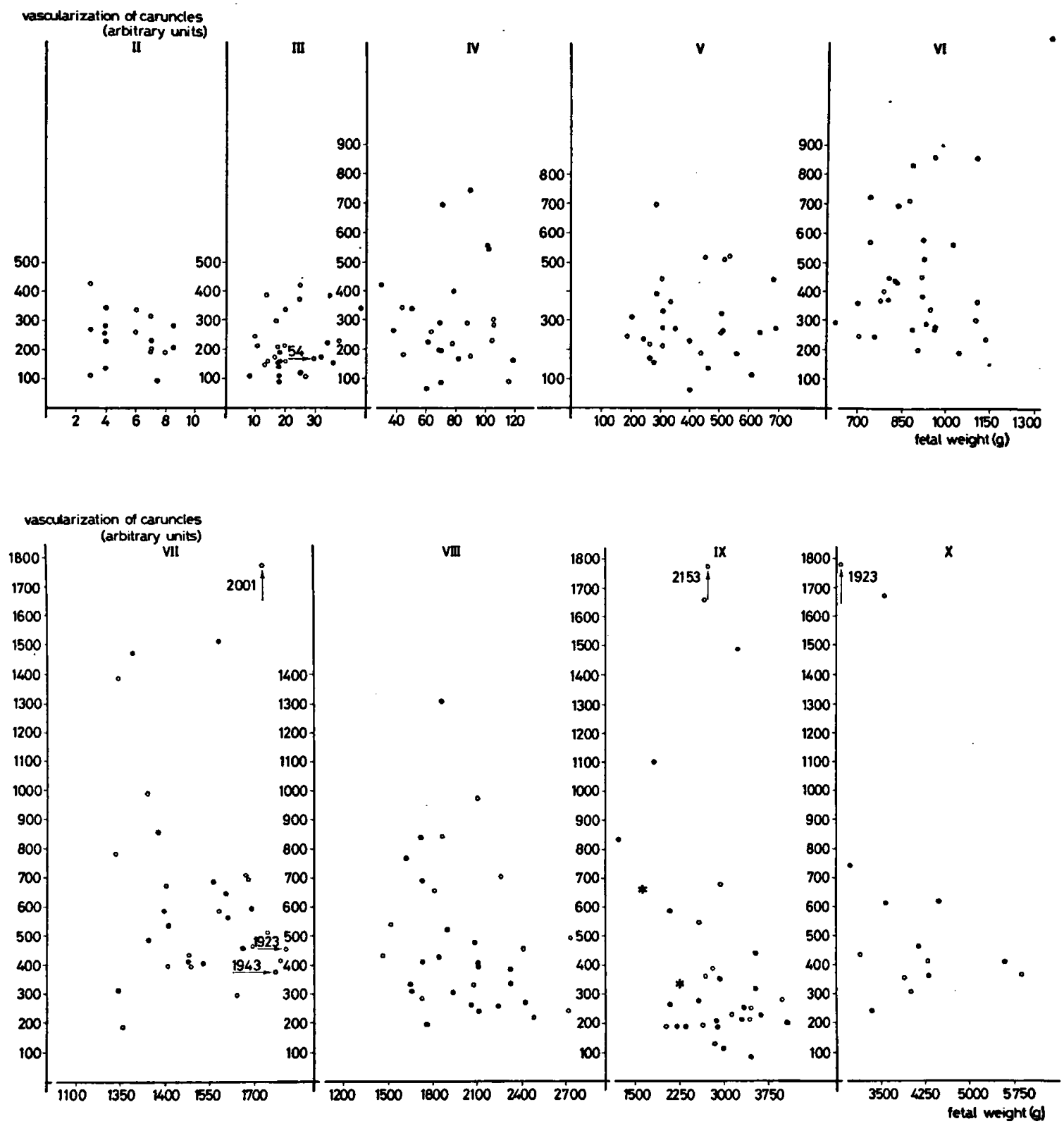

Fig. 35. The relationship between the vascularization of the caruncles and fetal weight.

group VII. In the older groups (after group VII) the vascularization of the caruncles no longer increases. The placenta also no longer increases its weight or its inner surface. Another factor now comes into play: if this total surface has turned out to be rather unfavourable, some measure of compensation may occur by means of the placental vascularization (see section 7). These considerations, involving a number of interesting factors, make it understandable that there is an absence of any correlation between the vasculariza- tion of the uterine component and the weight of the fetus.

Section 18. The relationship between the weight of the uterine horns and placental vascularization (fig. 36, table XII).

In group $\mathrm{X}$ there is a significant negative correlation between the weight of the uterine horns and placental vascularization. This correlation may be understood if it is taken into consideration that the cotyledonary weight is determined large- 

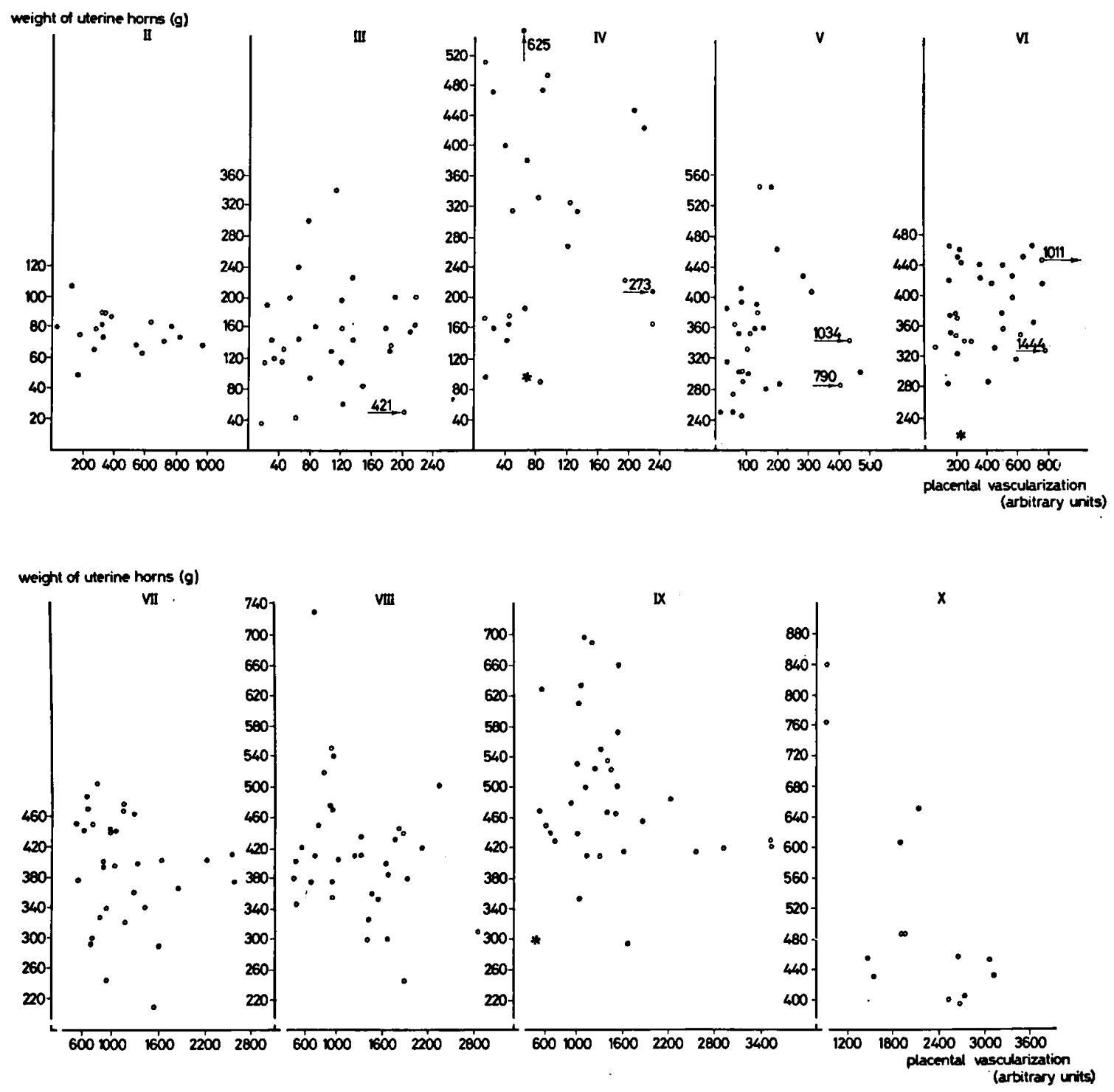

Fig. 36. The relationship between the weight of the uterine horns and placental vascularization.

ly by the weight of the uterus (see section 16). Thus, as a rule a small uterus will contain a small placenta. As was seen in section 4, the small placenta has a high degree of vascularization and these two relationships may explain the negative correlation mentioned above.

Section 19. The relationship between the vascularization of caruncles and the degree of branching (fig. 37, table XII).

Since a correlation between the vascularization of caruncles and the degree of branching is absent in all groups, it has to be concluded that the vascularization of the uterus does not play a role in the branching degree of the villi. It rather seems that the degree of branching, especially in groups II and III, depends on other factors such as the available space inside the uterus (cf. section 13). In later stages no differences whatsoever are found concerning the degree of branching.

Section 20. The relationship between placental vascularization and fetal weight (fig. 38, table XII).

The negative correlation seen in group II possibly reflects again the age differences within the group (see also section 3 ). In the very young age groups when the villi are very small, these 

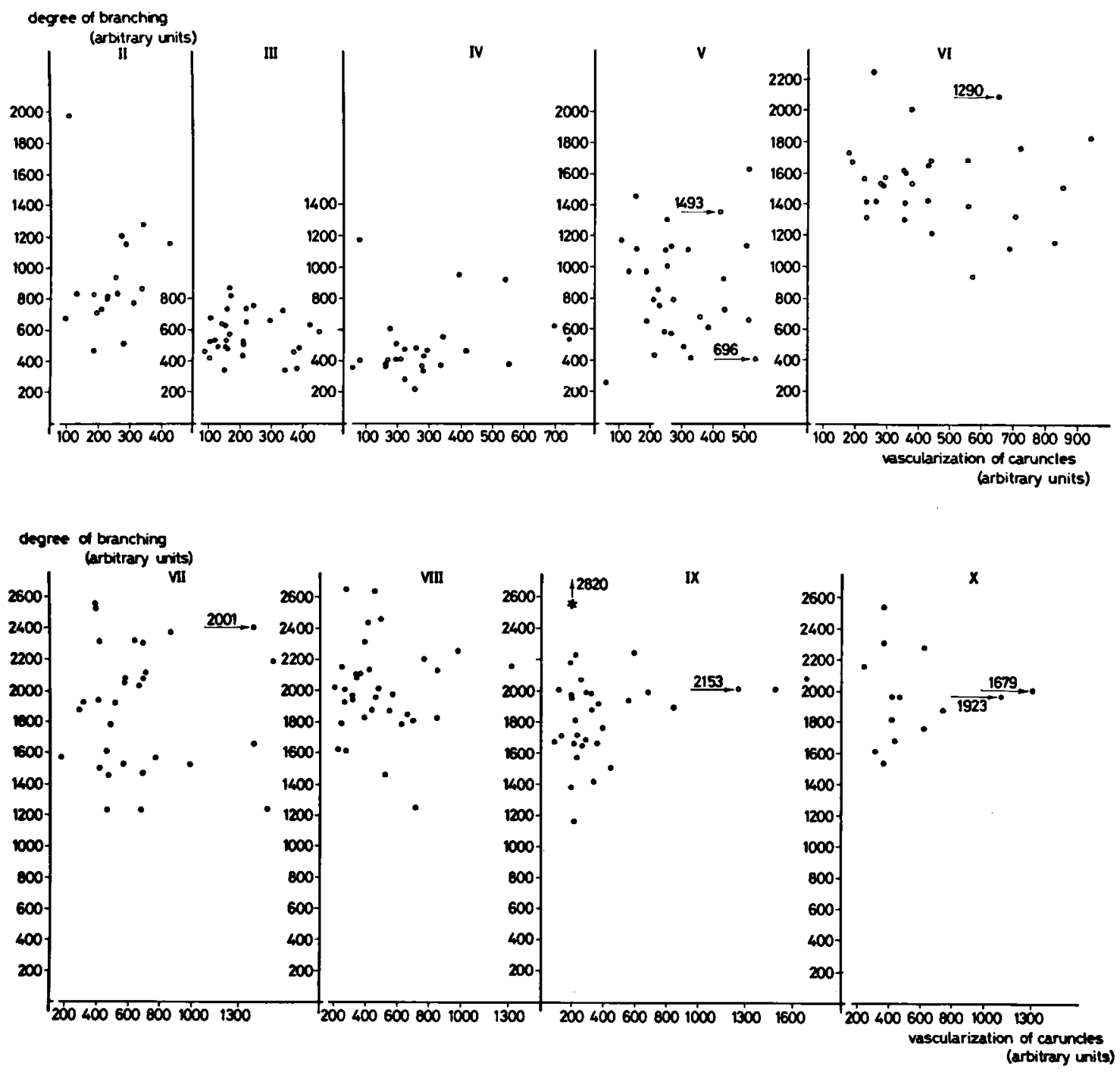

Fig. 37. The relationship between the vascularization of caruncles and the degree of branching.

appear to be very rich in blood vessels (see also $\S 4.4$, the development of the vascularization). These developmental stages are seen especially in the smallest embryos of group II.

In group VII a positive correlation is seen. It is in this group that the compensatory vascularization mechanism begins to come into play. Apparently, compensation at this stage still can be adequate. It is conceivable that in most cases the vascularization offers sufficient means of compensation all through pregnancy, but that in the later stages it is especially in the small placentas that the high degree of vascularization cannot fully compensate for the small size of the placenta so that the fetus lags behind in growth. Eventually in group $X$ the situation arises where a defi- nite negative correlation exists between the degree of vascularization and fetal weight.

In group $\mathrm{X}$ a highly significant negative correlation is seen between the placental vascularization and fetal weight. This means that a high vascularization in this group is mainly seen in combination with a small fetus. This is not surprising because in the higher groups (VII-X) a small fetus goes along with a small placenta, and a small placenta often has a higher vascularization than larger placentas (cf. section 4).

Section 21. The relationship between the vascularization of the caruncles and the weight of fetal membranes (fig. 39, table XII).

No significant correlation is found between the 

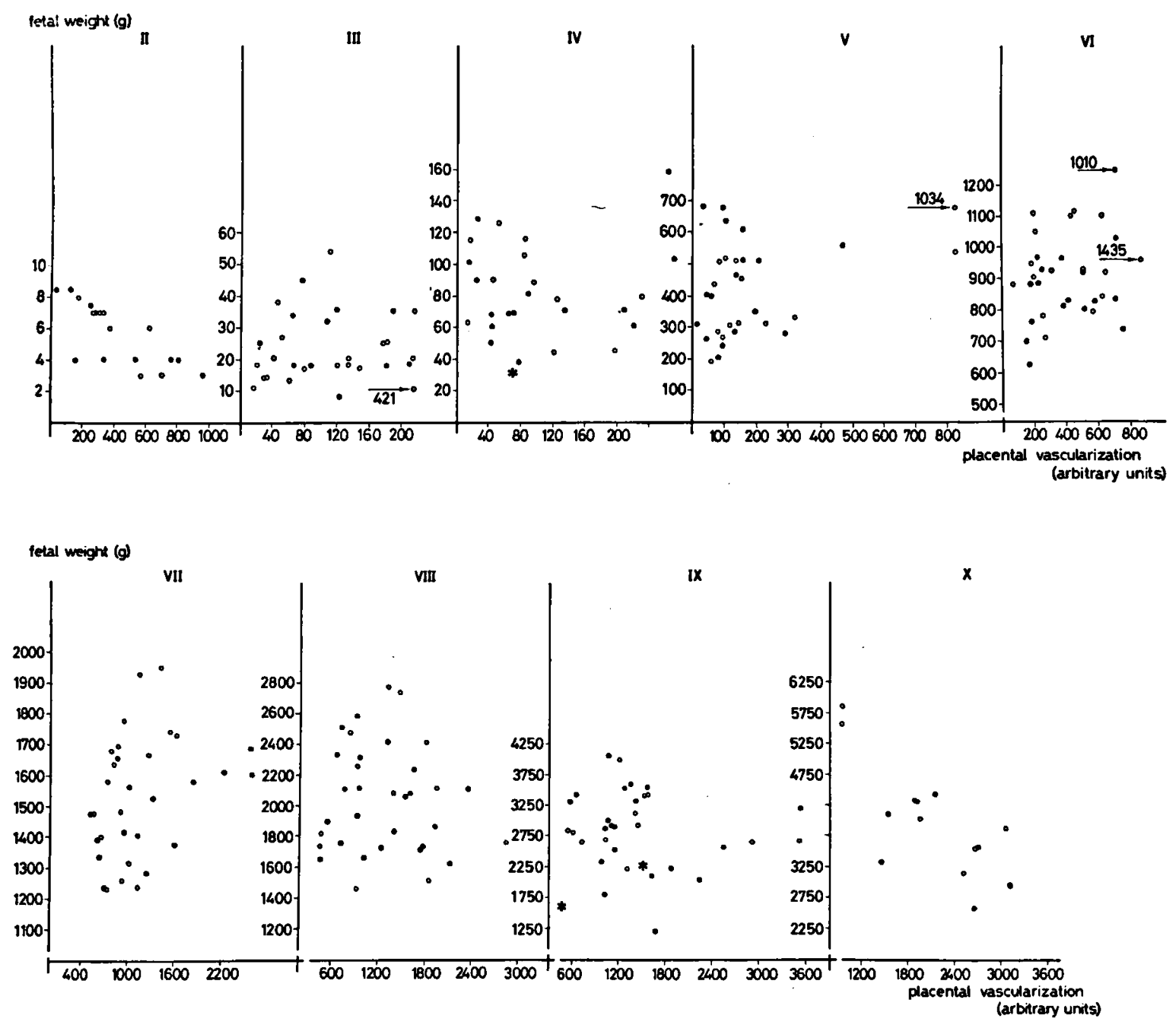

Fig. 38. The relationship between placental vascularization and fetal weight.

vascularization of the caruncles and the weight of the fetal membranes, with the exception of group VI, in which a significant positive correlation exists. In section 12 it was found that the weight of the total cotyledonary mass and the weight of the fetal membranes show a correlation in all groups. Since furthermore a significant positive correlation in group VI was found between the weight of the cotyledonary mass and the vascularization of the caruncles, a similar correlation between the vascularization of the caruncles and the weight of the fetal membranes was not unexpected.

Section 22. The relationship between the vascularization of the caruncles and the placental blood volume (fig. 40, table XII).
In groups III to $\mathrm{V}$ no significant correlation exists between the vascularization of the caruncles and the blood volume in the placenta.

Since the degree of vascularization in group VI is not yet very high, the blood volume at this stage is determined largely by the placental weight, bearing in mind the relationship between the vascularization of the uterus and the blood volume in the placenta (blood volume $=$ cotyledonary weight $X$ degree of vascularization). In groups VI, VII and VIII there is a definite positive correlation.

In the later age groups the placental weight decreases whereas the degree of vascularization shows a rise. In group IX the correlation is no longer significant, and in group $\mathrm{X}$ a slight tendency towards a negative correlation is even observed. 

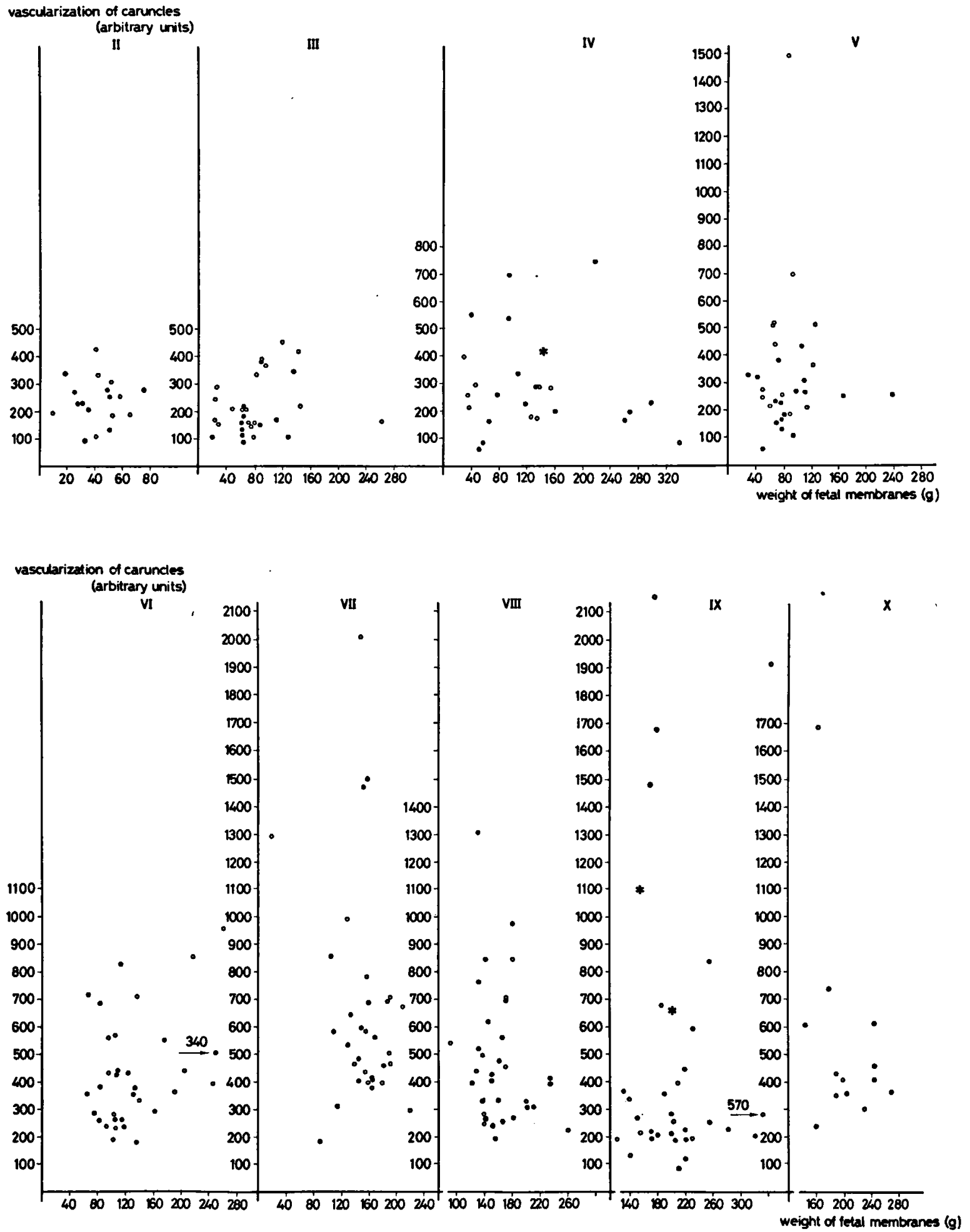

Fig. 39. The relationship between the vascularization of the caruncles and the weight of the fetal membranes. 

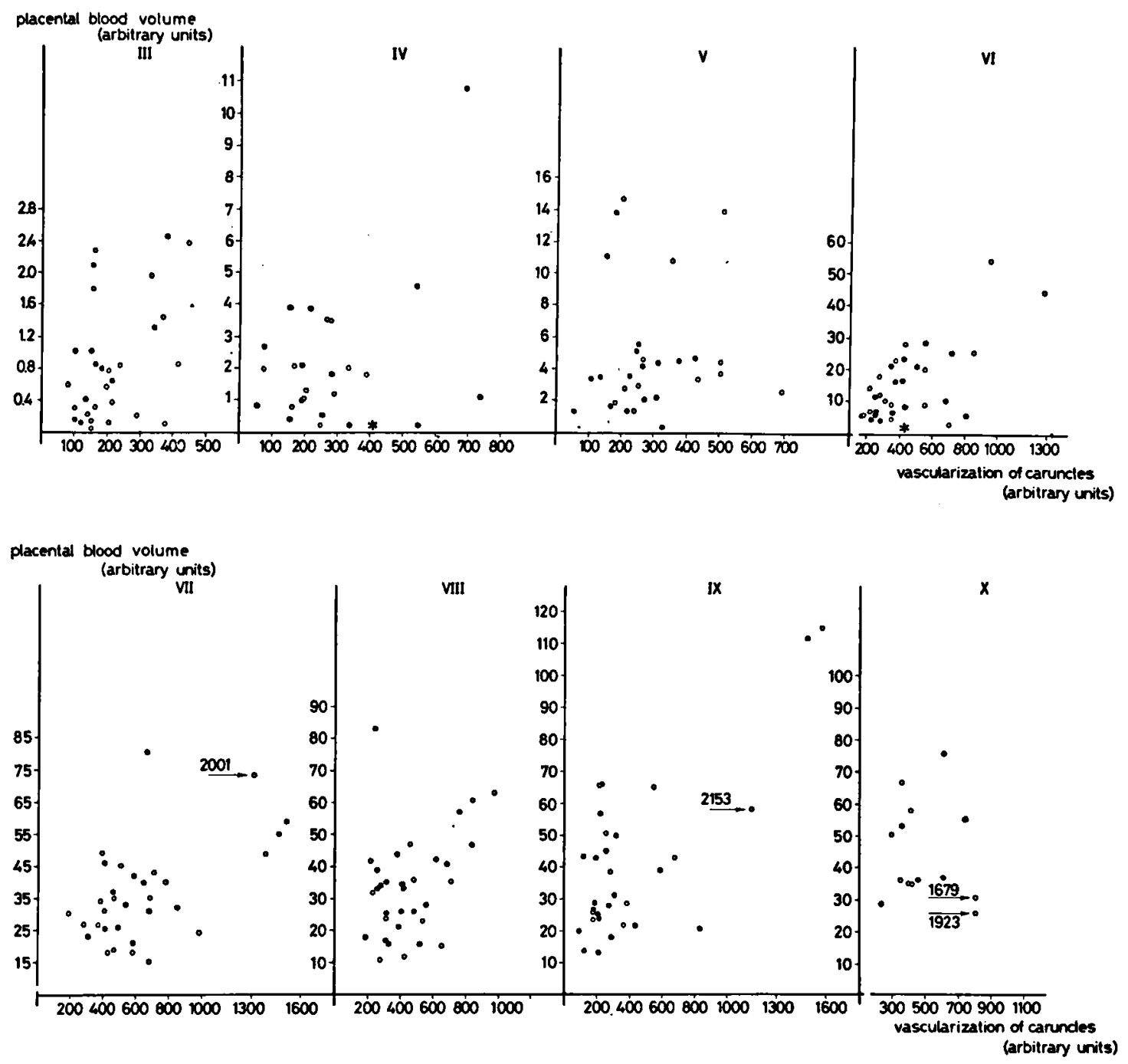

Fig. 40. The relationship between the vascularization of $t$ he caruncles and the placental blood volume.

Section 23. The relationship between the degree of branching and fetal weight (fig. 41, table XII).

The negative correlation between the degree of branching and fetal weight in group II reflects differences which may arise as a consequence of differences in age within the group. Early in this group the placenta is still forming primary villi in the endometrium; these young villi are small and numerous, a situation reflected in an apparent high degree of branching. The fetuses there are still very small. Somewhat later in group
II the fetuses increase in weight, but at the same time the villi swell, which is reflected in an apparent decrease in the degree of branching.

In groups $\mathrm{V}$ and VI a significant positive correlation is seen. This gives the impression that in this stage it is the degree of branching which to a large extent determines the efficiency of the placenta. In later age groups the correlation disappears since the degree of branching does not increase after group VIII. 

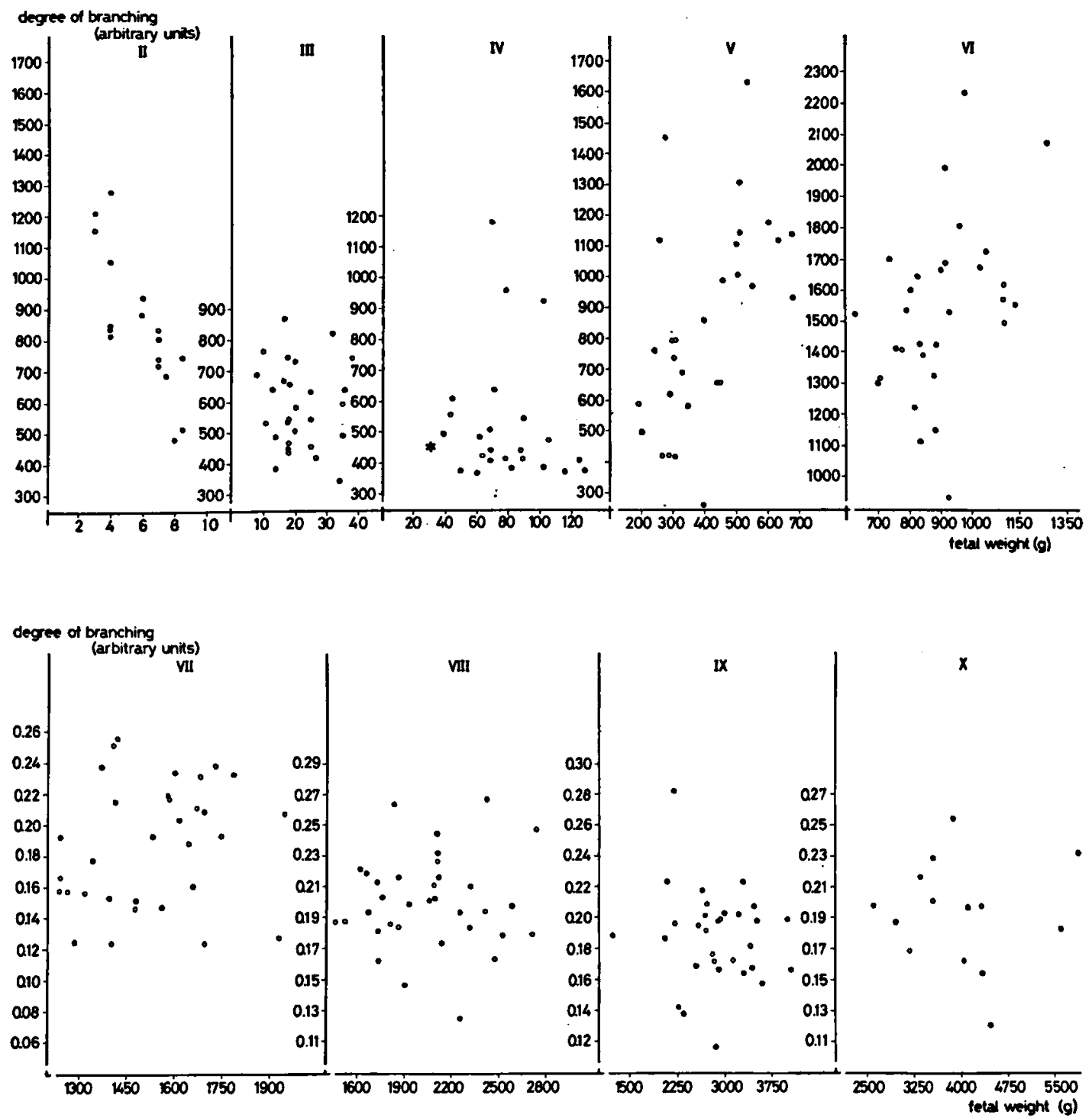

Fig. 41. The relationship between the degree of branching and fetal weight.

CHAPTER 5. DISCUSSION OF THE DATA ON TWIN PREGNANCIES

In this chapter an attempt will be made to integrate a number of the relationships discussed in chapter 4 into an overall concept covering the various factors which play a role in the determination of the fetal weight. This overall view is presented as a diagram (fig. 42).

In the first place it becomes clear from this diagram that the weight of the uterus is of direct importance in determining the weight of the placenta. Naaktgeboren \& Stegeman (1969) have already shown that for the sheep in all groups there is a positive correlation between the weight of the uterus and the weight of the total fetal sac or afterbirth (membranes plus cotyledons were weighed togethis).

From the diagram it can also be seen that in all groups there is a positive correlation between the weight of the uterus and the weight of the membranes. The temporary disappearance of this correlation has been discussed already in $\$ 4.7$ section 10 .

Furthermore, in all groups there is a definite positive correlation between the weight of the membranes and the cotyledonary mass. As regards the relationship: weight of the fetal membranes - 


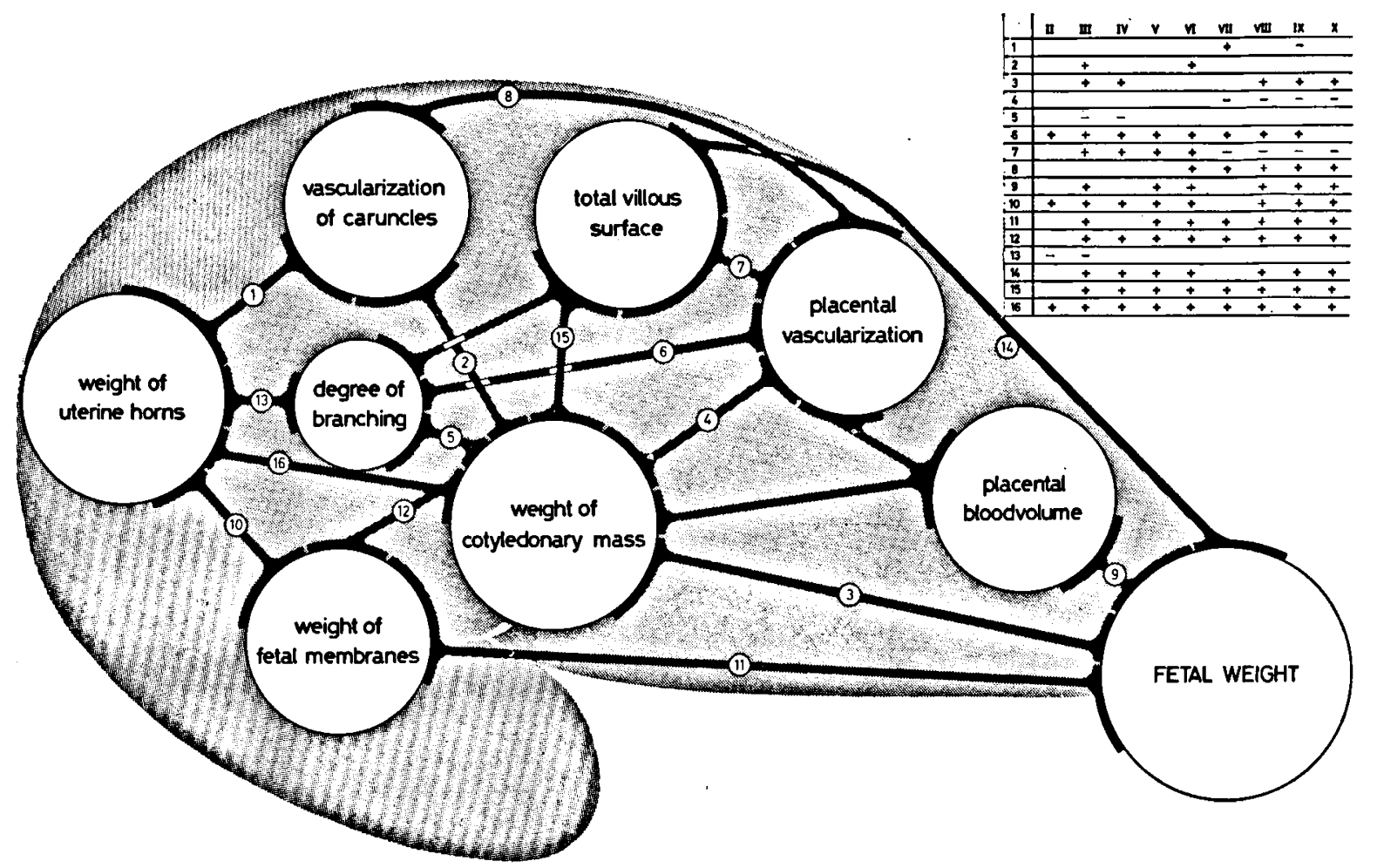

Fig. 42. Diagram of a number of relationships as described in $\S 4.7$. The heavy symbols in the table represent significant positive or negative correlations. Light symbols indicate that the correlation, though not significant, shows a strong positive $(+)$ or negative $(-)$ tendency. For the exact values, see table XII.

fetal weight, and weight of the cotyledonary mass fetal weight, it has to be remarked that the positive correlation which is seen in group III does not necessarily indicate a causal relationship; it is thought rather to reflect age differences within the group (as pointed out earlier, see $\S 4.7$ sections 11 and 3 ).

In the younger age groups the placenta can easily meet the demands made by the fetus. In later age groups it appears that the weights of cotyledons and membranes attained in groups $\mathrm{V}$ and VI are of prime importance for the further development of the fetus. From the finding that the correlation between cotyledonary weight and the vascularization of the cotyledons becomes negative, the conclusion seems warranted that, in cases in which the cotyledonary weight is low, the placenta has a compensatory mechanism at its disposal. It is the variable vascularization which may be considered as forming such a mechanism.

The striking negative correlation in the last part of pregnancy between the degree of vascularization and cotyledonary weight ( $\$ 4.7$ section 4) is also reflected in the relationship between the degree of vascularization and total villous surface (§ 4.7 section 7). This is quite understandable since a high correlation throughout pregnancy is found between the weight of the cotyledonary mass and the total villous surface ( $\$ 4.7$ section 15$)$.

Since it is the total amount of blood in the placental villi which is of prime importance for the fetus, it is plausible to suppose that there will be a connection between the fetal weight and the total amount of blood present in the placental villi (compare § 4.7, section 9). The correlation between "total villous blood volume" and fetal weight indeed becomes positive in the older age groups; the parameter "total villous blood volume" being calculated by multiplying the cotyledonary weight and the vascularization of the cotyledons. This seems quite understandable, but here the following remark should be made. Too small a villous surface theoretically can be a consequence both of a placenta which is too light or of a degree of branching which is too low. Since, however, branching as a part of the total differentiation pattern of the villi follows a similar 


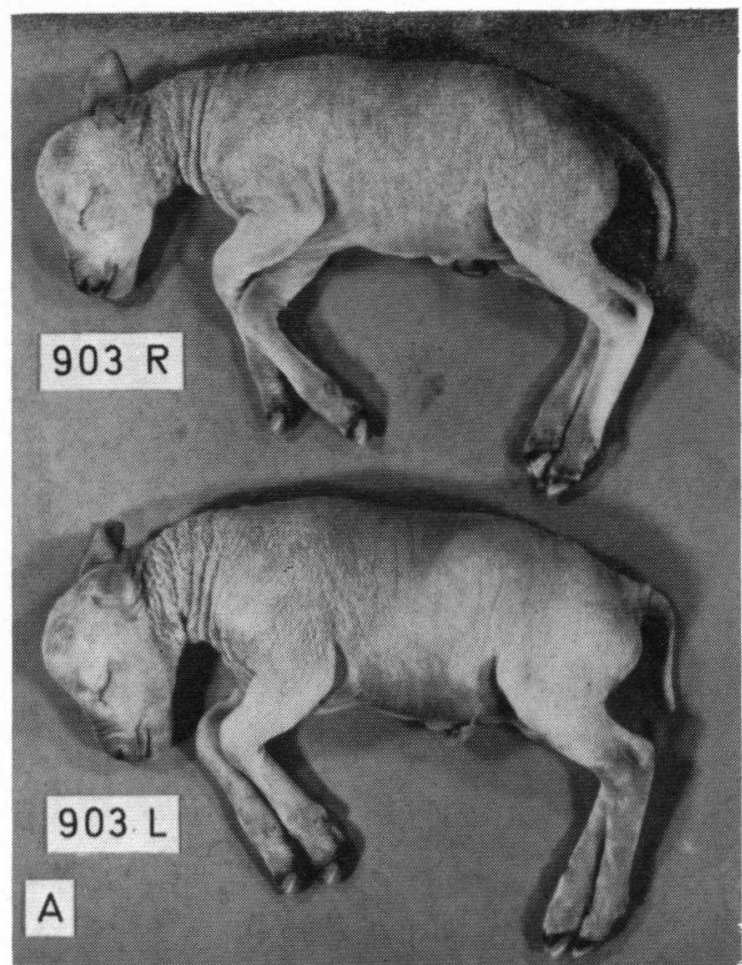

Fig. 43. A. Twin fetuses of group VIII. The difference in size between these male fetuses in quite obvious.

The weights of the fetuses (in $g$ ) and the data on the respective placentas (in arbitrary units) are:

fetal weight

cotyledonary weight

placental vascularization

blood volume

degree of branching

total villous surface

caruncular vascularization

B. Microscopic aspect of the placenta of no. $903 \mathbf{R}$.

C. Microscopic aspect of the placenta of no. $903 \mathrm{~L}$.

For abbreviations, see $\$ 2.3 .3 ; *=$ artificial space.
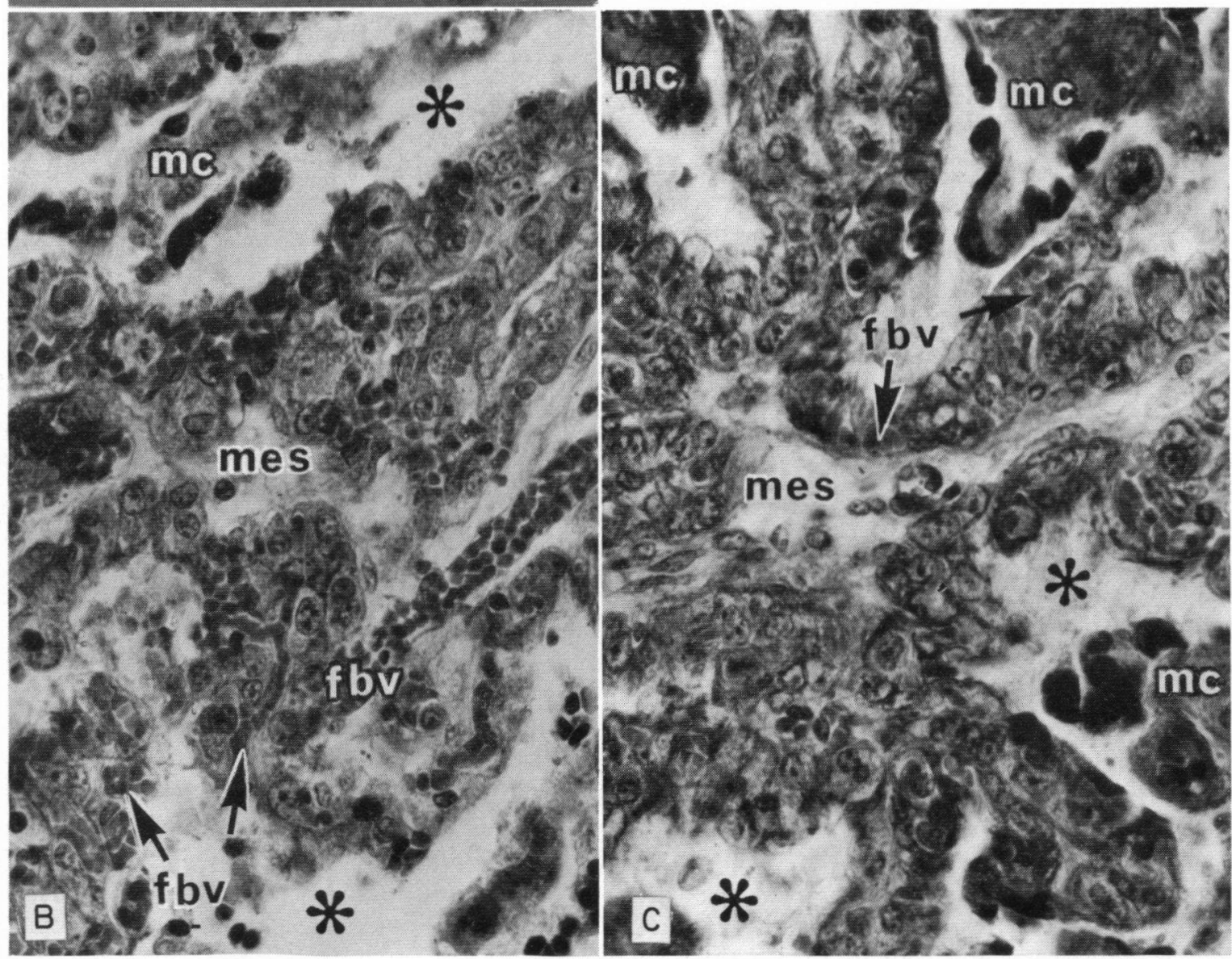
course in almost all placentas, (see also $\S 4.7$ section 15), proliferation of the blood vessels will practically always serve as a compensation for a small placenta rather than for variations in the degree of branching.

The mechanism of blood vessel proliferation, however, is not sufficient for complete compensation of differences in placental weight (and inner surface); this can be concluded from the positive correlation which exists between cotyledonary weight and fetal weight in the older age groups.

Such differences in birth weight are especially striking when dealing with lambs of the same sex present within one uterus.As an illustration of these differences the following case will be discussed in some detail (see fig. 43, A-C). Two male lambs were present in the right (R) and left (L) horn respectively of uterus no. 903 . On the basis of table I they are classified as belonging to group VIII. It is clear that 903 (R) in this state (46 weeks before parturition) is much lighter than its twin brother. If the total villous surface of the two placentas are compared, here also a definite difference comes to light: 45 units for the right, 75 units for the left fetus. (The average value for group VIII is 57 units; table IX). The placenta of the right fetus shows a much higher degree of vascularization than the placenta of the left fetus (degree of vascularization respectively 0.2152 and 0.0980 , the average value for this group being 0.1290 ). It should be noted that the total blood volume of the right placenta is even higher than that of the left placenta (59 and 37 units respectively, the average value for this group being 35 units). So it becomes clear in this example that it is not just the degree of vascularization which plays a decisive role, but that other factors also - especially the total villous surface - are of significance. Since the degree of villous differentiation (i.e. mainly branching) does not give any substantial means for compensation, and since the total placental surface therefore cannot be enlarged in this way, it seems obvious that it is by means of variations in the degree of vascularization that the given total villous surface functions in an optimal way.

From the diagram in fig. 42 it also appears that after group VI there is a positive correlation between the vascularization of the caruncles and the vascularization of the cotyledons ( $\$ 4.7$ section 8 ). This could mean that the placental mechanism for compensatory blood vessel proliferation only comes into operation if such a mechanism would indeed result in a better blood supply to the fetus, i.e., if the blood supply by the maternal component is not a restricting factor. As an illustration of this point, two fetuses are compared, 879 and $903 \mathrm{~L}$, a singlet and a twin both in age group VIII (fig. 44). Fetus 879 is a female singlet, its weight being only $1370 \mathrm{~g}$ (the average weight in group VIII is $2172 \mathrm{~g}$, table II). It is of significance that in the non-pregnant horn no part of the chorionic sac was present, which makes the case useful for comparison with a twin pregnancy, but which is a rather unusual situation in singlet pregnancies. The total villous surface was small, 19 units (average 78, table IX), the degree of vascularization of the caruncles was 0.0125 (the average in this group is 0.0587 for the pregnant horn of a singlet, or 0.0486 for twins, table XIV). The vascularization of the cotyledons was also low at 0.0655 units (the average value is 0.1418 units for the pregnant horn of a singlet, or 0.1290 in case of twins, table X). Thus it appears that in the case of fetus 879 no extra proliferation of the blood vessels had taken place. If this singlet no. 879 is com-

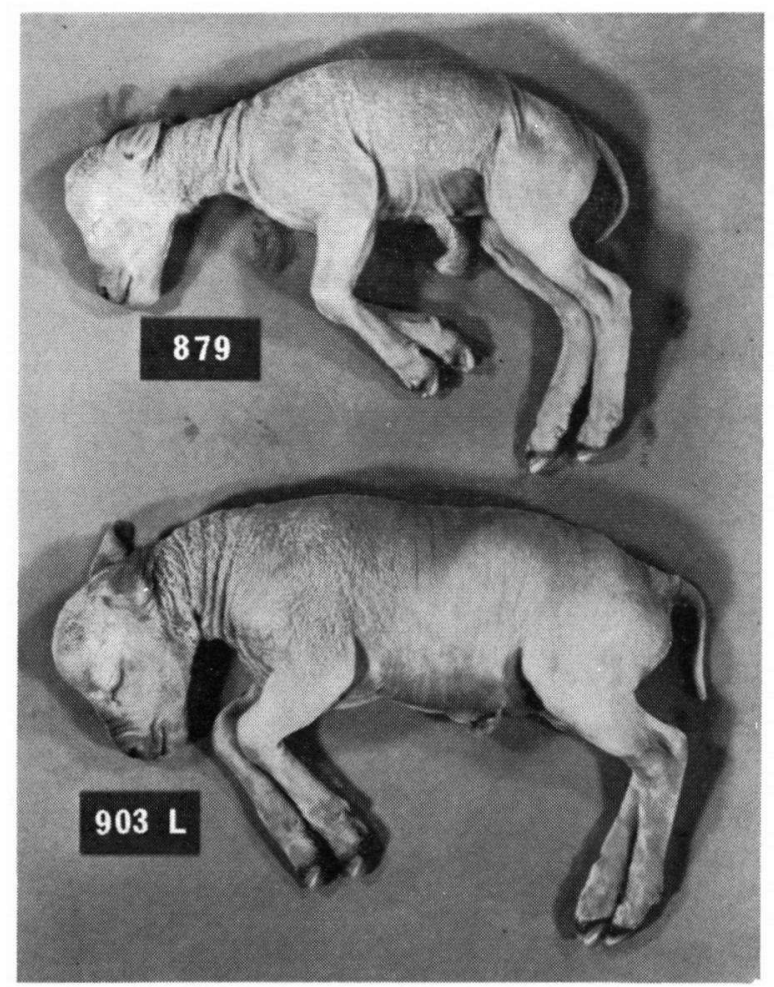

Fig. 44. Comparison of a twin fetus (903 L) and a singlet (879). The case of the singlet is of interest because only one horn contained cotyledons. For further details, see text. 
Table XIV. Vascularization of caruncles. Mean values $\pm 1 \times$ S.E.M. (expressed in arbitrary units). (The numbers of individuals are given in parentheses).

\begin{tabular}{|c|c|c|c|c|c|c|c|c|c|}
\hline Group & II & III & IV & V & VI & VII & VIII & IX & $\mathbf{x}$ \\
\hline $\begin{array}{l}\text { SINGLETS } \\
\text { non-pregnant } \\
\text { horn }\end{array}$ & (3) $\begin{array}{r}0.0142 \\
\pm 0.0094\end{array}$ & (4) $\begin{array}{r}0.0307 \\
\pm 0.0117\end{array}$ & (8) $\begin{array}{r}0.0334 \\
\pm 0.0065\end{array}$ & (4) $\begin{array}{r}0.0528 \\
\pm 0.0064\end{array}$ & (6) $\begin{array}{r}0.0466 \\
\pm 0.0082\end{array}$ & (6) $\begin{array}{r}0.0573 \\
\pm 0.0152\end{array}$ & $\begin{array}{r}\text { (14) } \\
0.0453 \\
\pm 0.0047\end{array}$ & $\begin{array}{l}\text { (15) } \\
\quad 0.0360 \\
\pm 0.0047\end{array}$ & - \\
\hline $\begin{array}{l}\text { SINGLETS } \\
\text { pregnant } \\
\text { horn }\end{array}$ & (3) $\begin{array}{r}0.0348 \\
\pm 0.0150\end{array}$ & (5) $\begin{array}{r}0.0197 \\
\pm 0.0024\end{array}$ & (7) $\begin{array}{r}0.0408 \\
\pm 0.0061\end{array}$ & (6) $\begin{array}{r}0.0479 \\
\pm 0.0073\end{array}$ & (6) $\begin{array}{r}0.0436 \\
\pm 0.0085\end{array}$ & (6) $\begin{array}{r}0.0507 \\
\pm 0.0089\end{array}$ & $\begin{array}{l}\text { (18) } \\
0.0587 \\
\pm 0.0082\end{array}$ & $\begin{array}{l}\text { (18) } \\
0.0557 \\
\pm 0.0076\end{array}$ & - \\
\hline TWINS & $\begin{array}{l}\text { (25) } \\
\quad 0.0256 \\
\pm 0.0051\end{array}$ & $\begin{array}{r}\text { (31) } \\
0.0215 \\
\pm 0.0039\end{array}$ & $\begin{array}{l}\text { (28) } \\
0.0289 \\
\pm 0.0055\end{array}$ & $\begin{array}{r}(30) \\
0.0333 \\
\pm 0.0061\end{array}$ & $\begin{array}{l}\text { (30) } \\
0.0472 \\
\pm 0.0086\end{array}$ & $\begin{array}{l}\text { (32) } \\
0.0665 \\
\pm 0.0118\end{array}$ & $\begin{array}{l}\text { (34) } \\
0.0486 \\
\pm 0.0083\end{array}$ & $\begin{array}{l}\text { (34) } \\
0.0467 \\
\pm 0.0080\end{array}$ & $\begin{array}{l}\text { (14) } \\
0.0621 \\
\pm 0.0166\end{array}$ \\
\hline RIPLETS & - & (9) $\begin{array}{r}0.0218 \\
\pm 0.0033\end{array}$ & (6) $\begin{array}{r}0.0237 \\
\pm 0.0037\end{array}$ & $\begin{array}{l}\text { (11) } \\
0.0273 \\
\pm 0.0033\end{array}$ & (6) $\begin{array}{r}0.0170 \\
\pm 0.0030\end{array}$ & (6) $\begin{array}{r}0.0186 \\
\pm 0.0027\end{array}$ & (3) $\begin{array}{r}0.0235 \\
\pm 0.0071\end{array}$ & (3) $\begin{array}{r}0.0247 \\
\pm 0.0035\end{array}$ & (3) $\begin{array}{r}0.0302 \\
\pm 0.0008\end{array}$ \\
\hline
\end{tabular}

pared with the above mentioned case of twins (no. 903), then it is obvious that in the case of the small singlet with its small placenta and its spare maternal blood supply there apparently is no compensatory blood vessel proliferation, whereas such a proliferation was definitely present in the case of $903 \mathrm{R}$, the smallest of the twins. As a consequence of this situation, fetus $903 \mathbf{R}$ lagged behind the twin brother $903 \mathrm{~L}$ (the fetal weights were 1900 and $2440 \mathrm{~g}$ respectively), but still has attained a much higher weight than the single fetus 879. In no. 879 no compensatory blood vessel proliferation has occurred, and it should be stressed that the vascularization of the caruncles is also much below the average for group VIII $(0.0125)$. The degree of vascularization of the caruncles of fetus $903 \mathrm{R}$ was 0.0310 , a value not differing as much from the average (0.0486) as in the case of fetus 879. Perhaps it is this difference in the vascularization of the maternal part of the placenta which has to be looked upon as a main cause for the non-development of a compensatory mechanism in fetus 879 . In this context it should be recalled that in $\S$ 4.7 section 8 , a positive correlation was found between the vascularization of the caruncles and the vascularization of the cotyledons, pointing to a possible dependence of placental vascularization on maternal blood supply.

In summary, the following tentative conclusions may be drawn from these considerations. The weight of the uterus plays an important role in determining the weight of the cotyledons. This cotyledonary mass in its turn largely determines the amount of placental surface area available for exchange when the differentiation of the pla- centa is completed in group VII or VIII. (The absolute weight of the cotyledons is already reached in groups $\mathrm{V}$ or VI). If the cotyledonary weight - and in a later stage, the total villous surface - is smaller than is necessary for optimal growth of the fetus, a compensation mechanism may become active. This mechanism consists of an extra proliferation of fetal blood vessels. It seems to become active only in those cases in which maternal blood supply is sufficient. However, this proliferation will not be sufficient to compensate fully for the disadvantages of a small placenta. Thus a small placenta will result in a small fetus in spite of this compensatory mechanism.

\section{CHAPTER 6. RESULTS. FINDINGS IN SIN- GLETS AND TRIPLETS}

\section{$\S 6.1$ Singlets}

The factual data on the fetal weight, the numbers and weights of the cotyledons, the weight of the membranes and the weight of the uterine horns are given in a preceding chapter (see chapter 3, tables II, III, IV, V and VI).

Firstly it may be remarked that, as a rule, cotyledonary weight, weight of membranes and fetal weight are significantly higher in singlets than in twins of the same age groups.

From the beginning the singlet is in a more favourable position than the average twin. It may be assumed that singlets and twins have the same growth potential at the moment they enter the uterine cavity. In twins the presence of a second conceptus has the early consequence that 
expansion of the fetal membranes is hampered by the fact that each fetus has only one horn at its disposal; in singlets about $1 / 3$ of the total placenta is accommodated in the non-pregnant horn. In those cases of singlet pregnancy in which the placenta develops in one horn only (e.g., fetus 907, table XV), this situation leads to a fetal and placental weight well below the average for single fetuses.

This fundamental difference between singlet and twin pregnancies renders comparison between singlet and twin pregnancies irrelevant, although a mutual comparison of singlet pregnancies seems to be useful.

In chapter 4 , mention is made of a number of correlations found between a number of parameters such as cotyledonary weight, degree of vascularization, blood volume, degree of branching and total villous surface. In view of these correlations it seems relevant to verify whether or not in the case of singlets these data and their relationships present a picture similar to the set of relationships regarding twin pregnancy as presented in chapter 4.

\section{Degree of branching (fig. 13, table VIII)}

On this point the development in the pregnant horn lags behind the development in the nonpregnant horn, the degree of branching in the non-pregnant horn being higher than in the pregnant horn. No undue significance has to be attached to this finding. On the grounds of considerations as given in $\S 4.2$, this higher degree of branching only means that the villi are less swollen than the villi which are present in the pregnant horn. In group $\mathrm{V}$ this difference has disappeared. In comparison with twin placentas, the degree of branching in singlet pregnancies remains lower until group VII; ultimately, however, it reaches a somewhat higher end-value.

\section{Total villous surface (fig. 14, table IX)}

It should be stressed first that in considering singlet pregnancies it always has to be kept in mind that the fetus has both horns at its disposal to accommodate its cotyledons.

It is clear from fig. 14 that the total villous surface until group VI is lower than in cases of twin and triplet pregnancies. However, the placenta can apparently meet the demands made by the fetus since in this group VI no significant differences in weight are seen between singlet and twin fetuses. In groups VIII and IX, it is seen, however, that the total villous surface (in both horns) is larger than in twin and triplet pregnancies.

\section{Degree of vascularization (table $\mathrm{X}$ )}

When one compares the pregnant and the nonpregnant horn it appears that in group III the degree of vascularization of the pregnant horn apparently is lower than in the non-pregnant horn. On this point the considerations given under the heading "branching" are valid also: a slower development of the placenta in the nonpregnant horn implies a lower degree of expansion of the villi and consequently a higher value for the relative degree of vascularization of the villi. At about group IV this difference disappears.

It has already been mentioned that singlet and twin pregnancies may be compared only with certain restrictions. When compared with the placentas in twin pregnancy, it appears that the placentas of singlets up to group VI show about the same degree of vascularization. In group VII the vascularization of singlets is even lower, but in later age groups it is higher than in twin pregnancies. This finding is rather unexpected, for if it is assumed that a high degree of vascularization is to some extent a compensatory mechanism for a small placenta, it would be expected in general that twin placentas would show a higher degree of vascularization than singlet placentas. It has to be kept in mind however that, as mentioned earlier, a singlet fetus is in a much more favorable situation from the very beginning of pregnancy. If it is further assumed that the strongly developing fetus will continue to make higher demands, these radically different circumstances could explain the finding that in singlet placentas there is an intensive proliferation of blood vessels.

\section{Vascularization of the caruncles (table XIV)}

As regards the vascularization of the caruncles in singlet pregnancies, no notable differences can be found between the uterus containing twins and the uterus in which only one fetus is present. On this point the uterus which contains three fetuses (see also $\S 6.2$ ) shows a considerable difference in caruncular vascularization in comparison with twins.

\section{Blood volume (table XI)}

The average blood volume of the singlet placenta in groups VI and VII is lower than for twins. This largely is a consequence of the lower 
Table XV. Comparison of fetus no. 909 (singlet group IX) and fetus no. 907 (singlet group X). Both fetuses are also compared with the mean values for each group.

\begin{tabular}{|c|c|c|c|c|c|c|c|}
\hline \multirow{3}{*}{$\begin{array}{l}\text { Fetal weight (g) } \\
\text { Weight of total } \\
\text { cotyledonary mass (g) }\end{array}$} & \multicolumn{2}{|c|}{\begin{tabular}{cc}
\multicolumn{3}{c}{ Fetus no. 909} \\
\multirow{2}{c}{ group IX } \\
pregnant & non-pregnant \\
horn & horn
\end{tabular}} & \multicolumn{2}{|c|}{$\begin{array}{l}\text { Mean values in group IX } \\
\text { pregnant } \text { non-pregnant } \\
\text { horn } \\
\text { horn }\end{array}$} & $\begin{array}{c}\text { Fetus no. } 907 \\
\text { \& group X }\end{array}$ & \multicolumn{2}{|c|}{\begin{tabular}{cc}
\multicolumn{2}{c}{ Mean values in group $X$} \\
pregnant & non-pregnant \\
horn & horn
\end{tabular}} \\
\hline & \multicolumn{2}{|c|}{4950} & \multicolumn{2}{|c|}{3264} & 4150 & \multicolumn{2}{|r|}{4613} \\
\hline & \multicolumn{2}{|c|}{330} & \multicolumn{2}{|c|}{327} & 240 & \multicolumn{2}{|r|}{319} \\
\hline $\begin{array}{l}\text { Weight of fetal } \\
\text { membranes (g) }\end{array}$ & 150 & 80 & 224 & 52 & 240 & 175 & 46 \\
\hline $\begin{array}{l}\text { Caruncular } \\
\text { vascularization } \\
\text { (arbitrary units) }\end{array}$ & 0.0194 & 0.0221 & 0.0557 & 0.0360 & 0.0536 & - & - \\
\hline $\begin{array}{l}\text { Degree of branching } \\
\text { of the villi } \\
\text { (arbitrary units) }\end{array}$ & 0.1444 & 0.1577 & 0.1938 & 0.2065 & 0.1435 & - & - \\
\hline $\begin{array}{l}\text { Total villous } \\
\text { surface } \\
\text { (arbitrary units) }\end{array}$ & 32.2 & $1.0^{38.8}$ & 43.9 & $1.7^{17.8}$ & 34.4 & - & - \\
\hline $\begin{array}{l}\text { Degree of } \\
\text { vascularization } \\
\text { (arbitrary units) }\end{array}$ & 0.2134 & 0.2158 & 0.1790 & 0.1418 & 0.2827 & - & - \\
\hline $\begin{array}{l}\text { Placental blood } \\
\text { volume }\end{array}$ & 21.6 & $.9^{28.3}$ & 30.4 & $4.6^{14.2}$ & 67.8 & - & - \\
\hline
\end{tabular}

(arbitrary units)

degree of vascularization; from group VIII upward the blood volume available for singlets is considerably greater than for twins. These high values are determined by both a higher cotyledonary weight and a higher degree of vascularization in the placentas of singlets.

For technical reasons it was not possible to give the same - very time consuming - treatment to the total material of singlets and triplets as was given to twins. A thorough treatment of the twin material was considered more relevant.

Table XVI lists the three cases of singlets in group IX with the highest birth weight, together with the three cases with the lowest birth weight. From this table it can be seen that in single pregnancies in cases where the placenta is small, a proliferation of blood vessels may occur just as in cases of twin pregnancies. Such a situation for instance may arise in cases where the placental tissue is present in one of the two horns only; in this respect these cases are comparable with twin pregnancies (no. 290 and 231 in table XVI). It may also happen that the pregnant uterus is small and that, for this reason, a large placenta has not developed (for example: no. 207). The extremely heavy fetus 909 is characterized by a very high degree of villous vascularization. It probably was genetically disposed to become a

large animal; although the placental weight was not far from the average, the cotyledons in this case coped with the high demand by a rather extensive proliferation of blood vessels.

Discussion of a few cases from the total material is illustrative.

It is of interest, for instance, to compare the heavy lamb 909 from group IX with the very light singlet lamb 907 from group X (fig. 45, table $X V)$. The average weight in group $X$ in the present material was $4613 \mathrm{~g}$ (table II). Lamb 909 weighed $4950 \mathrm{~g}$, lamb 907 weighed only $4150 \mathrm{~g}$. The cotyledonary weights of the two animals also were markedly different: $330 \mathrm{~g}$ for lamb 909, against $240 \mathrm{~g}$ for lamb 907. Although the cotyledonary weight of the heavy fetus 909 was about equal to the average for this group, the blood vessels in the placenta had proliferated extensively: the degree of vascularization $(0.2134$ for the pregnant, 0.2158 for the non-pregnant horn) was high (average for this group 0.1790 and 0.1418 respectively, table XV). The placental weight of fetus 907 was, as mentioned, far below the average for the group. The degree of vascularization however, was remarkably high: 0.2827 , much higher even than the values for the twin placentas in this group $X(0.2123)$, placentas which, as far as the available room is concerned, were in the same 

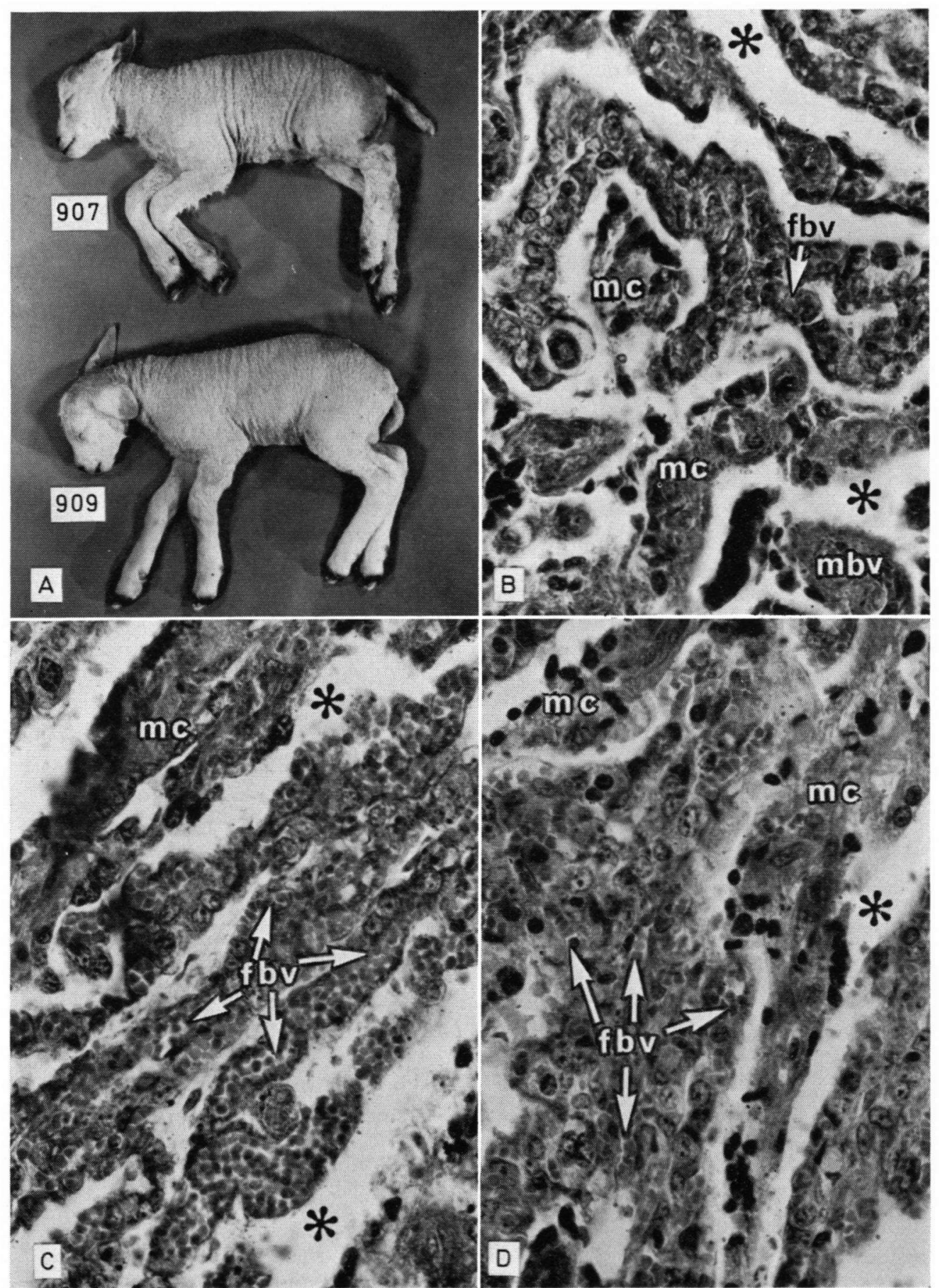

Fig. 45. A.Heavy fetus from group IX (909) compared with a fetus from group X (907) of normal weight; see also table XIV. The data on these animals are given in the text, $\$ 6.1$.

B. Microscopic aspect of the placenta of no. 907 (X 160).

C. Microscopic aspect of the placenta of no. 909 (pregna nt horn) $(\times 160)$.

D. Microscopic aspect of the placenta of no. 909 (vacant horn) $(\times 160)$.

For abbreviations, see $\$ 2.3 .3$. 
Table XVI. A listing of extreme cases of singlet pregnancy (group IX) : the 3 highest and the 3 lowest birth-weight values.

\begin{tabular}{|c|c|c|c|c|c|c|c|c|c|}
\hline Group IX & $\begin{array}{l}\text { Fetal } \\
\text { weight } \\
\text { (g) }\end{array}$ & $\begin{array}{r}\text { Weight o } \\
\text { ma }\end{array}$ & $\begin{array}{l}\text { cotyledonary } \\
\text { ss (g) }\end{array}$ & $\begin{array}{r}\text { Pla } \\
\text { vascu } \\
\text { (arbit }\end{array}$ & $\begin{array}{l}\text { Icental } \\
\text { larization } \\
\text { rary units) }\end{array}$ & $\begin{array}{r}\text { Vascul } \\
\text { ca } \\
\text { (arbit }\end{array}$ & $\begin{array}{l}\text { larization of } \\
\text { runcles } \\
\text { rary units) }\end{array}$ & Weight o & $\begin{array}{l}\text { f uterine horns } \\
\text { (g) }\end{array}$ \\
\hline & & $\begin{array}{l}\text { pregnant } \\
\text { horn }\end{array}$ & $\begin{array}{c}\text { non-pregnant } \\
\text { horn }\end{array}$ & $\begin{array}{l}\text { pregnant } \\
\text { horn }\end{array}$ & $\begin{array}{c}\text { non-pregnant } \\
\text { horn }\end{array}$ & $\begin{array}{l}\text { pregnant } \\
\text { horn }\end{array}$ & $\begin{array}{c}\text { non-pregnant } \\
\text { horn }\end{array}$ & $\begin{array}{l}\text { pregnant } \\
\text { horn }\end{array}$ & $\begin{array}{c}\text { non-pregnant } \\
\text { horn }\end{array}$ \\
\hline values & 우 3138 & 234 & 92 & 0.1790 & 0.1418 & 0.0557 & 0.0360 & 424 & 201 \\
\hline no. 186 \% & 3420 & 300 & 72 & 0.0685 & 0.0685 & 0.0467 & 0.0517 & 505 & 220 \\
\hline no. 221 s & 3350 & 240 & 54 & 0.1558 & 0.1601 & 0.0406 & 0.0512 & 560 & 85 \\
\hline no. 909 t & 4950 & 150 & 180 & 0.2134 & 0.2158 & 0.0194 & 0.0221 & 420 & 310 \\
\hline no. 290 \& & 1055 & 60 & - & 0.3849 & - & 0.0839 & - & 163 & 60 \\
\hline no. 231 ô & 1935 & 123 & - & 0.2342 & - & 0.0687 & - & 345 & 205 \\
\hline no. $207 \hat{\delta}$ & 1800 & 100 & 60 & 0.2209 & 0.1458 & 0.0609 & 0.0609 & 200 & 110 \\
\hline
\end{tabular}

circumstances. Thus both fetuses were characterized by a remarkable proliferation of blood vessels: the heavy fetus 909 probably in order to realize his heavy growth potential; the light fetus 907 to compensate for the unfavorable situation of the placenta.

In case 186, a female singlet in group IX, a degree of vascularization $(0.0685$, see table XVI) was found lying below the average $(0.1606$, table $\mathrm{X})$, but the weight of the fetus $(3420 \mathrm{~g}$, table $\mathrm{XVI}$ ) was well above the average value for female lambs in group IX (3138 g, table II). In trying to find an explanation for this apparent discrepancy it may be remarked that in this case the uterine weight of the ewe was exceptionally high (table XVI). The weight of the total cotyledonary mass was $372 \mathrm{~g}$ (mean value for females in this group was $325 \mathrm{~g}$, table V). The total placental blood volume comprised 25.4 units, whereas the mean value of this group was 44.6 (table XI). The total villous surface however, was 71.3 which is above the mean value of 61.7 units in group IX (table IX). Further it has to be mentioned that the weight of the total membranes was 298 $g$ (the average weight of the fetal membranes in group IX was $227 \mathrm{~g}$, table IV). Possibly it is in a combination of these findings that an explanation for the high birth-weight may be found. Wrobel \& Kühnel $(1966 ; 1968)$ studied the intercotyledonary chorion and they concluded that these intercotyledonary parts of the chorion also make an important contribution to the nutrition of the fetus.

Apart from the examples given above, in which a plausible explanation for the characteristics of the placenta can be put forth, there are a number of cases in which the data cannot be explained at present.

\section{$\S 6.2$ Triplets}

Before giving a description of the triplet pregnancies, one preliminary remark should be made concerning the one triplet pregnancy in group $\mathbf{X}$. In the total material only one uterus containing triplets belonged to group X. This case is exceptional in many respects. In the first place it can be observed that the fetal weights were higher than the average values for triplet lambs given in table II. The weight of the uterus was exceptionally high also (table VI); with its 1100 grams for the horn containing two fetuses and 470 grams for the horn with one fetus, it was the heaviest sample in the total material studied. Given the correlation found between placental weight and uterine weight it is not surprising that the placentas present in this uterus were exceptionally heavy (see table V); the same is true for the membranes (table IV). So the values for the placentas present in this uterus have to be considered as not representative for the average triplet at the end of pregnancy; the data therefore have to be interpreted with the utmost reserve. As some breeds are selected for bigger litters there is a possibility that, in the case mentioned above, the mother was not a pure Texel breed, which might have lead to the exceptional data.

Apart from the exceptional case mentioned above, the ultimate birth weight of triplets in most cases was well below the values of singlets and twins. In group VIII this growth retardation was clearly observable (see fig. 6, A). After group VIII the cotyledonary weight also was below the average for singlets and twins (see table $\mathrm{V}$ and fig. 8, A).

Degree of branching (fig. 13, table VIII)

It seems that in groups III and IV the degree 
of branching was higher than in twin pregnancies in these groups; probably as a consequence of the smallness of the villi. In groups $V$ to IX the average degree of branching was lower than in the average twin placenta.

As regards group $\mathrm{X}$, reference is made to the remark in the introduction of $\S 6.2$

Total villous surface (fig. 14, table IX)

In group III this surface was equal to the surface in twin placentas in the same group. In group IV the surface was even greater because of the higher degree of branching in this group. From group $\mathrm{V}$ onward the total surface remained lower than that in twin placentas; the course from then on was parallel to that of twins, although at a lower level.

\section{Degree of vascularization (table X)}

On the basis of correlations found in twin pregnancies, it was expected that the average small total surface of the villi would be correlated with a high degree of vascularization in triplet placentas. This appears not to be the case. In groups III and IV the degree of vascularization indeed was higher than in twin placentas. This correlation was only apparent since in these younger age groups the degree of branching was higher because the villi are smaller, and the proportion of the total villous volume occupied by the blood vessels therefore was relatively greater. When the villi start expanding, the degree of vascularization decreases and in groups V and VI it was equal to that in twin pregnancies. In groups VII to IX the degree of vascularization clearly remained behind that in twin pregnancies.

\section{Blood volume (table XI)}

In groups III and IV it was found that the blood volume of each placenta was higher than in twins, for the same reason as mentioned above. In the older groups however, after group $\mathrm{V}$, the blood volume remained less than that in twin pregnancies. As was mentioned in the beginning of this paragraph, the triplets of group $X$ are excluded from this rule.

\section{Vascularization of the caruncles (table XIV)}

In comparison with singlets and twins, it was striking that up to group IV the degree of vascularization of the caruncles was about equal in all three groups. In later age groups the average degree of vascularization of the caruncles in trip- lets was always lower. In $\S 4.7$ section 8 , it was shown that in twins a positive correlation exists between the degree of vascularization of the caruncles and the vascularization of the cotyledons. A similar dependance possibly explains the finding that no extra vascularization was present in triplet pregnancies in which, given the low weight of the placentas, such a compensation was to be expected. The high demands made upon the uterine circulation leads to the situation that vascularization of the caruncles reaches its maximum. As a consequence no extra vascularization of the villi develops.

\section{$\S 6.3$ Comparison of singlets and triplets with twins}

The data for singlet and triplet placentas are neither contradictory to the correlation diagram given in chapter 5, nor to the hypothesis of a compensatory mechanism present in the placenta. Furthermore, a number of the findings in singlet and triplet pregnancies may be explained on the basis of the correlations found in twin pregnancies.

The vascularization of the cotyledons until group VII in singlets is lower than in twins; in the higher age groups proliferation of blood vessels occurs, probably as a consequence of higher demands made by the singlet with its strong tendency to maximal growth.

In twin pregnancies a correlation was found between the vascularization of the caruncles and the vascularization of the cotyledons. It was considered that uterine vascularization is a limiting factor for the proliferation of the fetal blood vessels. A similar mechanism might explain why in triplet pregnancies, with their maximal demands on the uterine circulation, the placenta does not react with a high degree of blood vessel proliferation.

The average degree of branching in the triplet placenta is lower than that of the twin placenta; consequently the total villous surface is also smaller. Since a compensatory vascularization of the villi does not occur, this combination of factors explains the definite lagging behind of the weights of triplets in age groups VIII to $X$.

As regards the degree of branching, it should be recalled that for twin pregnancies, especially in the lower groups (II and III) a negative correlation was found between the weights of the uterus and the degree of branching. This finding fits in with the finding that in singlets, which have 
more room than twins, it is especially in these lower groups that a low degree of branching is found. In triplet pregnancy, on the other hand, where the total available space is divided between three fetuses, it appears that the degree of branching in the lower groups is higher. It may be concluded for all categories that the more uterine space is available for each fetus, the lower will be the initial degree of branching of the villi.

In the higher age groups the reverse is true; ultimately it is the placenta of the singlet pregnancy which shows the highest degree of branching followed by twins; the triplets show the lowest degree of branching.

Apparently, the early development of the placenta plays a role in the later potential for differentiation; this early potential in its turn is determined largely by the available space in the uterus. In the higher age groups it appears that the degree of vascularization of the caruncles (i.e., an uterine factor) determines whether or not proliferation of blood vessels will take place. Once again these considerations point to the definite influence of the uterine environment.

\section{CHAPTER 7. DISCUSSION}

The results confirm that the total amount of functional uterine tissue available is of prime importance in determining placental mass. In all groups studied (II-X), a significant positive correlation is present between the parameters of uterine weight and of weight of the total cotyledonary mass. This finding fits in the views put forward by other investigators. Walton \& Hammond (1938) executed reciprocal crosses between Shire horses and Shetland ponies. In genetically similar fetuses these workers found that the placentas were far heavier in the Shire horses than in the Shetland ponies. A decisive factor, apparently, was whether the mother was a Shetland pony with a small uterus or a Shire horse with a much larger uterus.

A similar conclusion may be drawn from the findings of Hunter et al. (1954), obtained during transplantation experiments with sheep. Fertilized eggs of sheep of the same breed were implanted into ewes of different breeds; the results pointed to a very large influence of the uterine environment on the development of the fetuses. Also for pigs (Pani et al., 1963); Smidt, 1966) and cattle (Lampo, 1965), data may be found which point to the importance of the uterus for the development of the fetus.
For many mammals it may be stated that the weight of the uterus does not return to its original value during involution after the first pregnancy (Naaktgeboren \& Stegeman, 1969). The differences in placental weight between primigravid and pluriparous animals can therefore be explained to a large extent by differences in size and weight and/or vascularization between uteri of such different backgrounds.

A similar uterine factor probably is active in the human. Studies by Dugal, Baird, Tellsley, Drillien and others (according to Kloosterman, 1967) have brought to light the curious fact that the socio-economic circumstances of the grandfather on the mother's side are of greater influence on determining birth weight than the socio-economic circumstances of the father of the child. This finding is interpreted as follows: if the mother in her youth grows up under favourable circumstances her uterus can develop well, so it presents an optimal environment for a fetus to develop. In the literature indications are found which substantiate the supposition that the developing uterus is indeed highly sensitive to nutritional influences. The influences were shown to exist by Amir et al. (1968).

Not only differences in placental weight but also differences in birth weight between the first child and later offspring may be explained by taking into account a better functioning of the uterus in later pregnancies, in which the placentas (and, consequently, the fetuses) become heavier.

It has been demonstrated for a number of species, including man, that placental weight is highly correlated with birth weight (for a review, see Naaktgeboren \& Stegeman, 1969). In earlier studies and also in the material of this study, it has been shown for sheep that this correlation is not present in all stages of pregnancy. In the younger age groups (III and IV) a positive correlation is found between cotyledonary weight and fetal weight, which can be attributed to age differences within the group (see $\$ 4.7$ section 3 ). It was also shown that placental weight does not increase after age group $V$, but that the inner surface keeps on increasing until age group VII or VIII. The significance of the placenta in determining fetal weight is connected with the total area of the surface at which exchange between maternal and fetal circulation takes place.

Placental weight and total villous surface show a significant positive correlation in all groups. Al- 
though the differentiation of the villi (and, consequently, the increase in the area of exchange) proceeds until age group VII or VIII, it is the placental weight reached around group $\mathrm{V}$ which sets the limit to the ultimate area of exchange. Branching (differentiation) apparently follows a fixed course in all cases and shows almost no variation.

After group VIII placental weight shows a significant positive correlation with total inner surface on one hand, and with fetal weight on the other hand. In younger age groups these correlations are absent. This development is to be expected if it is taken into account that in the last phase of pregnancy the fetus goes on growing strongly, making the highest demands upon the efficiency of its nutritional system; in other words, it is during this stage that the placenta is the principal determining factor in reaching a certain birth weight.

It is not possible to obtain human placentas and fetuses from all stages of undisturbed pregnancy. Yet there is evidence, as discussed in the introduction, that the placenta does not keep growing until the end of pregnancy. This evidence points to a fetal growth-limiting factor present in the placenta (Kloosterman \& Huidekoper, 1954; Kloosterman, 1965; 1970). Aherne \& Dunnill (1966) have demonstrated a positive correlation between the total surface of the villi of the placenta and birth weight. This relation has been shown not only for man but also for a great number of mammals (Baur, $1970 \mathrm{a}$ and b; 1972). The study of Aherne \& Dunnill (1966) also showed that in cases of premature children with a low birth weight the total surface of the villi was much smaller than in normal cases. A two-fold explanation may be given for this phenomenon: 1 . placental surface and fetal weight follow parallel developmental patterns, a view implying that the placenta forms a unit with the fetus in the same way as the fetus and its limbs form a unit; 2 . one of the components (the placenta) is of primary significance and can be a factor limiting fetal growth if its potential is subnormal. From the data in sheep, the second explanation seems most attractive. It could be demonstrated in the sheep that the macroscopic development of the placenta reaches its maximum at around the halfway mark in pregnancy; at that point the placenta no longer gains weight. About 4 - 6 weeks before the end of pregnancy (which has a duration of
21 weeks), differentiation of the villi also comes to an end. Although placental weight and total inner surface show a high degree of correlation all through pregnancy, it is only in group VIII that a positive correlation between placental weight (and total inner surface) and fetal weight becomes manifest. The consequence is that at term a high correlation between total inner surface (and weight) and fetal weight is found. It is clear, however, that this correlation is not present in all stages, but makes its appearance after placental differentiation has come to an end.

Kloosterman states that in man premature birth can occur in cases in which the placenta is exceptionally small, whereas large placentas predispose to a longer duration of pregnancy (Kloosterman \& Huidekoper, 1954; Kloosterman, 1970). It is by virtue of their large inner surface that these placentas can meet the demands of the growing fetus longer, resulting in higher birth weights. This gives the impression that the inner surface (and weight) of the human placenta keeps on increasing continuously. In the sheep the difference between the calculated date of parturition and the actual date amounts to a few days only. A delivery which is 10 days late is highly exceptional. In all these instances exceptionally heavy lambs and large placentas are found, a connection which is also found in man. In the cases of sheep it is certain, however, that the total surface of the villi stops growing several weeks before the end of pregnancy; this leads to the conclusion that in this animal the development of very big lambs has taken place due to a placenta which is very large in the first instance. However, the prolonged pregnancy in these cases could be the result of bigger progesterone production by the big placenta, which might inhibit uterine mobility for a longer time.

It has been argued that in the present material the variability of vascularization has to be looked upon as a compensatory mechanism for the disadvantages of a very small placenta. After age group VII a negative correlation becomes apparent between placental weight and degree of vascularization and also between total inner surface and degree of vascularization. The compensation is not complete; this follows from the fact that, notwithstanding this mechanism, small placentas are always correlated with small fetuses.

In man a similar phenomenon may be observed, viz. the condition of maturitas praecox, mentioned in the introduction. In these cases a definite 
discrepancy is found between the duration of pregnancy and the histological "maturity" of the placenta (Becker, 1960; 1963; Werner, 1972). Applying a number of criteria as mentioned by Becker (1960) (e.g. a strong proliferation of blood vessels in the villi), the placenta in these cases has to be classified as "mature". The newborn in these cases is underweight, but on the whole shows the characteristics belonging to the actual duration of pregnancy. The impression is obtained that in those cases the placenta has partially coped with the demands made by the fetus for as long as possible by means of an excessive proliferation of its blood vessels. It may be wondered whether also in other conditions in which the functioning placental surface is reduced, by infarctions for instance, an accelerated maturation of the placenta can take place. This question cannot be answered. It has been shown in man that severe infarction is accompanied by low birth. weight (Fox, 1967; Kloosterman \& Huidekoper, 1954). Schuhmann (1969) has described a single case of pregnancy of 41 weeks' duration in which about half the placenta had become non-functional by infarction in the early months. The remaining functional parts showed the histological picture of a normal fully-matured placenta. The weight of the newborn was 1200 grams, placental weight was 580 grams. It is clear that the low weight of the newborn has to be attributed to the damage inflicted upon the placenta very early in pregnancy. Since the condition of maturitas praecox, in which a fully matured placenta is present (Becker, 1960), often leads to premature birth, there is no indication that an accelerated maturation has taken place in the case described by Schuhmann (1969).

A last point of discussion is the significance of the vascularization of the uterus for the development of the placenta and the fetus and for the occurrence of the vascuiar compensatory mechanism. In sheep the extent to which the proliferation of the blood vessels can increase in the placenta appears to be highly dependent on uterine blood supply. If the vascularization of the uterus (the caruncles) is poor, the placental vessels show a far smaller tendency to proliferate than in cases where vascularization is abundant. In a number of cases (e.g. no. 879, fig. 44) a placenta was present in which, on account of its weight, the development of a compensatory vascularization could be expected, but which, however, did not occur. This possibly was due to a low degree of vascularization of the caruncles seen in these cases. The fetuses were much retarded in growth.

A condition in which a similar limiting role is played by uterine vascularization is met in triplets. In these cases the degree of vascularization of the uterus is relatively low compared with twins and singlets. The placental blood vessels fail to proliferate and the growth of triplet fetuses is much retarded.

The question comes up whether or not weight difference in man between singlets and twins after the 32nd week and between first and later born children are due to a failing of a compensatory proliferation of placental vascularization to develop as a consequence of a relatively insufficient maternal circulation. In other words: with regard to the occurrence of maturitas praecox, are there differences between twins and singlets and between first and subsequent pregnancies?

If in man also the maternal blood supply is a prerequisite of (compensatory) blood vessel proliferation in the placental villi, it is in these instances that differences may be expected.

Thus it seems certain that in man the uterus plays an important role in the functioning of the placenta. Thanks to its capacity for blood vessel proliferation the placenta can compensate for the disadvantages inherent in a small size, but it seems to react in this way only if it is advantageous, no limitations on the maternal side being present.

\section{SUMMARY}

In human reproductive physiology the placenta plays a crucial role. Conditions affecting the placenta are of prime importance for the course of pregnancy and for the development of the fetus.

The questions underlying the present study are:

1. How does the size of the placenta in normal pregnancy influence the development of the fetus?

2. Is it possible to determine whether certain parameters of placental differentiation are of special significance for the development of the fetus?

3. To what extent is the placenta in its turn influenced by the condition of the uterus and by the number of embryos present?

4. Has the normal placenta some mechanism at its disposal to compensate for certain shortcomings, such as unfavorable uterine conditions or small size? 
The last question results from the occurrence of a condition in human pregnancy, maturitas praecox, which is considered to be an accelerated maturation of the placenta as a response to certain unfavourable circumstances.

For obvious reasons, human material covering all phases of normal pregnancy is not easily available. Therefore the present study was performed on material from normal sheep found to be pregnant in the slaughterhouse. It was found in an earlier study that it is possible to classify pregnancies according to certain characteristics of the fetuses. Thus the duration of total pregnancy could be divided into 10 age groups (I-X) of more or less equal length.

It was also found earlier that the cotyledonary placenta of the sheep does not increase in weight during the last stages of pregnancy. A specific question pertaining the sheep pregnancy therefore was: how does the placenta cope with the increasing demands made by the growing fetus?

The study dealt most extensively with twin pregnancies, which are considered physiological in the Texel sheep in so far that twin pregnancies tend to predominate in this breed since their selection is for animals producing twins and triplets. They are comparable to human pregnancies in that the uterus is completely filled during pregnancy.

Some 566 pregnant uteri were collected from Texel sheep. The material consisted of 235 cases of single pregnancy, 285 cases of twin pregnancy and 45 cases of triplet pregnancy. In only one case quadruplets were found. Macroscopic data obtained included:

- weight of the uterine horns,

- weight of fetal membranes,

- weight of total cotyledonary mass,

- weight of the fetus.

Qualitative and especially quantitative microscopic data were mainly obtained from 252 twin pregnancies. By random selection, a total of 30 placentas in each of the 9 age groups (group I was not studied, in this group only the number of cotyledons was determined) was aimed at. Quantitative estimations of the two main parameters (degree of villous branching and the degree of vascularization) were obtained by used of a linesampling method and a point-sampling method respectively. From quantitative macroscopic and microscopic data the parameters "total blood volume of the villi" and "total villous surface" were calculated.
The fetal weights show a continuous increase. About 4-6 weeks before the end of gestation the weights of singlets, twins and triplets diverge, singlets becoming heavier than twins, twins becoming heavier than triplets.

The weight of the total cotyledonary mass shows a steep increase up to the middle of gestation, placentas of singlets being heaviest at that moment. From this moment, cotyledonary weights decline.

The number of cotyledons is fixed at the very beginning of gestation (group I) and then remains constant. The number of cotyledons is highest in single pregnancies, triplets having the smallest number of cotyledons.

The weights of the fetal membranes increase continuously. Membranes of singlets are heavier, and those of triplets are lighter than those of twins.

The weights of the uterine horns show a steep increase until about the middle of gestation. Thereafter growth is continuous, but the curve is less steep. Uteri containing triplets grow faster and reach higher end values than those containing twins, while the uteri containing one fetus only have the lowest growth rate.

In twin pregnancies the following quantitative microscopic data were obtained:

- The vascularization of the maternal component of the placenta (the caruncles) increases until age group VII, and remains constant in groups VIII-X.

- The degree of branching of the villi increases until age group VIII, and remains constant in groups $\mathrm{IX}$ and $\mathrm{X}$.

- The total villous surface shows a rise until age group VII and a slight decline in groups VIII-X.

- The vascularization of the villi shows a constant increase from group $V$ to group $X$.

- The total villous blood volume increases continuously to the end of gestation.

A total of 23 correlations has been worked out statistically, of which 16 correlations are integrated into a diagram.

Microscopic data of singlet and triplet pregnancies are discussed in relation to the diagram mentioned above. From the correlation-diagram the following conclusions are drawn:

1. Fetal weight is largely determined by placental weight.

2. The placental weight in its turn is largely dependent on uterine weight.

3. Uterine weight, membrane weight and fetal weight are correlated. 
4. Branching of the villi follows a constant invariable pattern.

5. Villous vascularization is variable and presents a compensatory mechanism in cases of a light placenta. The condition of extensive compensatory blood vessel proliferation shows similarities with the human condition of maturitas praecox.

6. The compensatory proliferation of villous blood vessels only becomes manifest if the maternal vascularization is adequate.

\section{SAMENVATTING}

De placenta speelt bij de voortplantingsfysiologie een beslissende rol. Omstandigheden, welke van invloed zijn op de placenta, zijn van primair belang voor het verloop van de zwangerschap en voor de ontwikkeling van de foetus.

De volgende vraagstellingen liggen ten grondslag aan het huidige onderzoek:

1. Op welke wijze beïnvloedt de afmeting van de placenta bij een normale zwargerschap de ontwikkeling van de foetus?

2. Is het mogelijk te bepalen of er bepaalde parameters in de differentiatie van de placenta aanwezig zijn die voor de ontwikkeling van de foetus van bijzonder belang zijn?

3. In welke mate wordt de placenta op zijn beurt beinvloed door de toestand van de uterus en het aantal embryonen dat aanwezig is?

4. Beschikt de normale placenta over een of ander mechanisme om bepaalde tekortkomingen, zoals bijvoorbeeld een ongunstig intra-uterien milieu of een te kleine afmeting, te compenseren?

De laatste vraag komt voort uit een bij de mens voorkomende situatic, namelijk maturitas praecox, die wel beschouwd wordt als een versnelde rijping van de placenta ten gevolge van bepaalde ongunstige omstandigheden.

Om voor de hand liggende redenen is het niet gemakkelijk de beschikking te krijgen over menselijk materiaal van alle perioden van de zwangerschap. Daarom werd het onderzoek uitgevoerd aan materiaal van normale schapen, die wanneer zij geslacht werden, zwanger bleken te zijn.

In een vorig onderzoek werd reeds aangetoond dat men de zwangerschap op grond van een aantal karakteristieke kenmerken van de foeten in klassen kan indelen. Op deze wijze was het mogelijk de totale duur van de zwangerschap in 10 ongeveer even lange perioden te verdelen.

Ook was reeds gevonden dat de cotyledonaire placenta van het schaap in de laatste stadia van de zwangerschap niet meer in gewicht toeneemt. Er bestond dus voor de zwangerschap bij het schaap een specifiek probleem: hoe kan de placenta tegemoet blijven komen aan de steeds toenemende eisen van de foetus?

Het onderzoek heeft vooral betrekking op tweelingen, aangezien deze voor het Texelsche schaap fysiologisch zijn in zoverre dat zij vaak voorkomen, daar dit ras speciaal geselecteerd wordt op het werpen van tweè- en drielingen. Men kan ze vergelijken met de zwangerschap bij de mens, omdat bij tweeling-zwangerschap bij het schaap de uterus bicornis totaal benut wordt.

Er werden ongeveer 566 zwangere uteri van Texelsche schapen verzameld. Het materiaal bestond uit 235 eenlingen, 285 tweelingen, 45 drielingen en 1 geval van vierling-zwangerschap. De volgende macroscopische gegevens werden verzameld:

- gewicht van de uterushoorns

- gewicht van de vruchtvliezen

- gewicht van de totale massa cotyledonen

- gewicht van de foetus

Kwalitatieve en vooral kwantitatieve microscopische gegevens werden verzameld van 252 tweelingen. Er werd naar gestreefd per leeftijdsgroep 30 placenta's te bestuderen die willekeurig uitgezocht waren. De twee belangrijkste parameters (vertakkingsgraad der vlokken en vascularisatiegraad) werden berekend door gebruik te maken van respectievelijk een snijpunten- en puntentelmethode. Door combinatie van de kwantitatieve macroscopische en microscopische gegevens werden de parameters "totale bloedvolume in de vlokken" en "totale oppervlak van de vlokken" berekend.

Het foetale gewicht vertoont een doorlopende stijging. Rond de 4-6 weken vóór het einde van de draagtijd gaan de gewichten van een-, twee- en drielingen verschillen, met dien verstande dat dan eenlingen zwaarder worden dan tweelingen, tweelingen zwaarder dan drielingen.

Het gewicht van de totale massa cotyledonen neemt snel toe tot halverwege de zwangerschap, terwijl de placenta's van eenlingen dan het zwaarst zijn. Daarna daalt het gewicht van de cotyledonen.

Het aantal cotyledonen wordt aan het begin van de zwangerschap vastgelegd (groep I) en blijft constant. Het aantal cotyledonen is het grootst bij eenlingen, terwijl drielingen de minste cotyledonen hebben.

Het gewicht van de vruchtvliezen neemt voortdurend toe. De vliezen van de eenlingen zijn het zwaarst en die van drielingen zijn weer lichter dan van tweelingen.

Het gewicht van de uterushoorns vertoont een scherpe stijging tot halverwege de zwangerschap. Daarna is de groei gelijkmatig, maar de helling is minder sterk. Uteri met een drieling groeien sneller dan die waarin een tweeling aanwezig is, terwijl uteri met een eenling het minst snel groeien.

Bij tweelingen werden de volgende microscopische gegevens verkregen:

- de vascularisatie van het moederlijk deel van de placenta (de caruncels) stijgt tot groep VII en blijft daarna gelijk;

- de vertakkingsgraad van de villi neemt toe tot groep VIII en blijft hetzelfde in de groepen IX en X;

- het totale oppervlak van de vlokken neemt toe tot groep VII en daalt iets in de groepen VIII-X;

- de vascularisatie van de villi stijgt vanaf groep $V$ $\mathbf{t} / \mathrm{m} \mathrm{X}$

- het totale „bloedvolume" der vlokken stijgt tot het einde van de $z$ wangerschap.

In totaal werden 23 correlaties statistisch bewerkt, waarvan 16 in een schema weergegeven (fig. 42).

Microscopische gegevens van een- en drielingen werden aan de hand van bovengenoemd schema besproken. Uit dit cörrelatie-diagram kunnen dè volgende conclusies getrokken worden: 
1. Het geboortegewicht van de foetus is sterk afhankelijk van het placentagewicht.

2. Het placentagewicht is sterk afhankelijk van het uterusgewicht.

3. Gewichten van uterus, vruchtvliezen en foetus houden met elkaar verband.

4. De vlokken vertakken zich volgens een vast patroon.

5. De vascularisatie van de vlokken is wisselend en kan in geval van een lichte placenta als compensatiemechanisme optreden. Deze grote proliferatie van bloedvaten bij wijze van compensatie kan vergeleken worden met de bij de mens optredende situatie in gevallen van maturitas praecox.

6. Deze compensatoire groei van de vaten in de vlokken treedt alleen op wanneer de moederlijke vascularisatie (uterus) overeenkomstig is.

\section{LITERATURE}

Abdel-Raouf, M. \& M. A. El-Naggar, 1969. The biometry of the gravid uterus in Egyptian buffalo cows. Zentbl. Vetmed., (A) $16: 838-854$.

Aherne, W. \& S. Dunnill, 1966. Quantitative aspects of placental surface. J. Path. Bact., 91 : $123-139$.

Alexander, G., 1964a. Studies on the placenta of the sheep (Ovis aries L.) placental size. J. Reprod. Fertil., 7 : 289-305.

,$- 1964 \mathrm{~b}$. Studies on the placenta of the sheep (Ovis aries). Effect of surgical reduction in the number of caruncles. J. Reprod. Fertil., 7 : 307-322.

Amir, S., J. Kali \& R. Volcani, 1968. Influence of growth rate on reproduction and lactation in dairy cattle. In : G. A. LODGE \& G. E. LAMming eds., Growth and development of mammals : $234-247$. (Butterworth, London).

BARCROFT, J., 1946. Researches on prenatal life : 1-76. (Blackwell Scientific Publications, Oxford).

BARCrofT, J. \& D. H. BARron, 1946. Observations upon the form and relations of the maternal and fetal vessels in the placenta of the sheep. Anat. Rec., 94 : 569-596.

Barcroft, J. \& J. A. KenNedy, 1939. The distribution of blood between the foetus and the placenta in sheep. J. Physiol., 95 : 173-186.

BATTAGLIA, F. C., 1970. Intrauterine growth retardation. Am. J. Obstet. Gynec., 106 : 1103-1114.

BAUR, R., 1970a. Úber die Relation zwischen Zottenoberfläche der Geburtsplacenta und Gewicht des Neugeborenen bei verschiedenen Säugetieren. Z. Anat. EntwGesch., 131 : 31-38.

,$- 1970 \mathrm{~b}$. Morphometrische Untersuchungen an frühembryonalen menschlichen Placenten: Beziehungen zwischen Grösse der Zottenoberfläche der Placenta und Volumen von Embryo und Placenta. Z. Anat. EntwGesch., 132 : 299-304.

-, 1972. Quantitative Analyse des Wachstums der Zottenoberfläche bei der Placenta des Rindes und des Menschen. Z. Anat. EntwGesch., 136 : 87-97.

Becker, V., 1960. Über Maturitas praecox Placentae. Verh. dt. Ges. Path., $44: 256-259$.

-, 1963. Funktionelle Morphologie der Placenta. Arch. Gynäk., 198 (3) : 1-28.

BuörKMAN, N., 1965. Fine structure of the ovine placentome. J. Anat., 99 : 283-297.

- , 1970. An atlas of placental fine structure: 18-36. (Baillière, Tindall \& Cassell, London).

Boyd, J. D. \& W. J. Hamilton, 1970. The human placenta : 1-335. (W. Heffer \& Sons Ltd., Cambridge).

Braun, L. \& K. H. Mosler, 1970. Über den Einfluss des Fruchtvolumens auf das Uteruswachstum der Ratte in der Schwangerschaft. Arch. Gynäk., 209 : 106-115.
Busch, W., 1972. Die Placenta bei der fetalen Mangelentwicklung. Arch. Gynäk., 212 : 333-357.

Cloethe, J. H. L., 1939. Prenatal growth in the merino sheep. Onderstepoort J. vet. Sci. Anim. Ind., 13 : 417-547.

Creasy, R. K., C. T. Barrett, M. de Swiet, K. V. KAHANPÄ̈̈ \& A. M. RUdoLPH, 1972. Experimental intrauterine growth retardation in the sheep. Am. J. Obstet. Gynec., 112 : 566-573.

Davies, J. \& W. A. Wimsatt, 1966. Observations on the fine structure of the sheep placenta. Acta anat., 65 : $182-223$.

DrieuX, H. \& G. ThIÉRY, 1952. La placentation chez les mammifères domestiques. Recl Méd. vét., 127 : 5-18.

Fox, H., 1967. The significance of placental infarction in perinatal morbidity and mortality. Biol. Neonat., 11 : 87-105.

Grosser, O., 1927. Frühentwicklung, Eihautbildung und Placentation : 101-110. (J. F. Bergmann, München).

HOFF, F. \& R. BAYER, 1952. Hormonale und mechanische Bedingnisse für das Wachstum des menschlichen Uterusmuskels in der Schwangerschaft. Zentbl. Gynäk., 28 : 1095-1101.

Hunter, G. L., C. E. Adams \& L. E. Rowson, 1954. Successful inter-breed transfer of ova in sheep. Nature, Lond., 174 : 890.

Kloosterman, G. J., 1963. Placenta en perinatale sterfte met zogenaamd onbekende orzaak. Bull. Soc. $r$. belge Gynéc. Obstét., 33 : 23-33.

- , 1965. Hoe lang groeit de menselijke placenta. Ned. Tijdschr. Verlosk., 65 : 202-216.

-, 1967. Leerboek der Verloskunde: 310. (Van Dishoeck, Bussum).

,- 1970 . On intrauterine growth. Int. J. Gynaec. Obstet., 8 : 895-912.

Kloosterman, G. J. \& B. L. Huidekoper, 1954. The significance of the placenta in obstetrical mortality. Gynaecologia, 138 (5) : 529-550.

Kublr, F., 1964. Zum Problem der Plazentarinsuffizienz. Praxis, 53 : 113-117.

LAMPO, P., 1965. Invloed van enkele factoren op het geboortegewicht van kalveren. Land- en Tuinbouw Jaarboek, 20 : $133-136$.

Ludwia, K. S., 1962. Zur Feinstruktur der Maternofetalen Verbindung im Placentom des Schafes (Ovis aries L.). Experientia, $18: 212$.

Malan, A. P. \& H. H. Curson, 1936. Studies on sex physiology, 15. Further observations on the body weight and crown-rump length of Merino foetuses. Onderstepoort J. Vet. Sci. Anim. Ind., 7 : 239. 
MERZ, W. A., 1967. Die Streckenmessung an gerichteten Strukturen im Mikroskop und ihre Anwendung zur Bestimmung von Oberflächen-Volumen-Relationen im Knochengewebe. Mikroskopie, 22 : 132-142.

NaAktgeboren, C. \& J. H. J. Stegeman, 1968. Spontane geboorte bij primaire ooien van het Texelsche schaap. Tijdschr. Diergeneesk., 93 : 745-756.

- \& -, 1969. Untersuchungen über den Einfluss des Uterus und der Plazenta auf das fetale Wachstum und das Geburtsgewicht, mit besonderer Berücksichtigung des Schafes. Z. Tierz. Züchtungsbiol., 85 (3) : 245290.

NaAkTgeboren, C., M. F. Bakker-Slotboom, M. J. Van Maren \& J. H. J. Stegeman, 1971. Die Geburt beim Texelschaf und beim Heideschaf, ein Beitrag zur Kenntnis der Domestikationseinflüsse auf den Geburtsverlauf. Z. Tierz. Züchtungsbiol., 88 (2): $169-182$.

Pani, S. N., B. N. Day, L. F. Tribble \& J. F. Lasley, 1963. Maternal influence in swine as reflected by differences in reciprocal crosses. Res. Bull. Univ. Missouri, 830 : $1-19$.

ReYnolds, S. R. M., 1949. Physiology of the uterus : 183-261. (P. B. Hoeber Inc., New York).

Richter, J. \& R. Götze, 1950. Tiergeburtshilfe : 48-49. (Paul Parey, Berlin, Hamburg).

SchumanN, R., 1969. Hypotrophes reifes Kind am Termin aus placentarer Ursache (sogenannter placentarer Zwerg). Beitr. path. Anat., 138 : 426-435.

ScotT, J. M. \& J. M. JoRdan, 1972. Placental insufficiency and the small for dates baby. Am. J. Obstet. Gynec., 113 : 823-832.

ScotT, K. E. \& R. UscheR, 1966. Fetal malnutrition : its incidence, causes and effects. Am. J. Obstet. Gynec., 94 : $951-963$.

SMIDT, D., 1966. Fortpflanzungskapazität und intrauterine Entwicklung bei Zwergschweinen. Vortrag 40sten Hauptversammlung der Tagung der deutschen Gesellschaft für Säugetierkunde in Amsterdam, 3-7 Okt. 1966.
Steven, D. H., 1968. Placental vessels of the foetal lamb. J. Anat., 103 : 539-552.

Wallace, L. R., 1948. The growth of lambs before and after birth in relation to the level of nutrition. $J$. agric. Sci., Camb., 38 : 243-303.

Wallenburg, H. C. S., 1969. Über den Zusammenhang zwischen Spätgestose und Plazentarinfarkt. Arch. Gynäk., 208 : $80-90$.

- , 1971. On the morphology and pathogenesis of placental infarcts: 1-168. (Thesis, Free University, Amsterdam).

Walton, A. \& J. HAMmond, 1938. The maternal effects on growth and conformation in Shire horse-Shetland pony crosses. Proc. R. Soc. Lond., (B) 125 : 311316.

WEIBEL, E. R., 1969. Stereological principles for morphometry in electron microscopic cytology. Int. Rev. Cytol., 26 : 235-302.

Werner, Ch., 1972. Plazentamorphologie und perinatale Medizin. Med. Mschr., 26 (2) : 54-56.

Wigglesworth, J. S., 1964. Morphological variations in the insufficient placenta. J. Obstet. Gynaec. Brit. Cwlth, 71 : 871-884.

Wijvekate, M. L., 1963. Verklarende statistiek. Het onderscheiden van toeval, schijn en werkelijkheid in cijfermateriaal : 1-232. (Het Spectrum, Utrecht).

WimsatT, W. A., 1950. New histological observations on the placenta of the sheep. Am. J. Anat., 87: 391458.

Winick, M., A. Coscin \& A. Noble, 1967. Cellular growth in human placenta. I. Normal placental growth. Pediatrics, 39: 248-252.

Wrobel, K. H. \& W. KüHNeL, 1966. Zur Fermenthistochemie von Uterindrüsen und Uterusepithel in der geburtsreifen Schafplacenta. Z. Anat. EntwGesch., 125 : $357-366$.

— \& -, 1968. Zur Fermenthistochemie der Schafplazenta. Morph. Jb., 3 (4) : 590-594.

Received : 7 August 1973. 